\title{
Fra Felstedskov til Frøslev
}

\author{
- mit livs historie 1920-1995
}

\section{af Marie C. Jessen}

\section{Prisopgaven: \\ »Sønderjyske erindringer siden Genforeningen i 1920«}

I 1993 udskrev Historisk Samfund for Sønderjylland en prisopgave. Vi opfordrede alle æaldre, som har levet og virket $i$ grænselandet, til at nedskrive deres erindringer. Erindringerne skulle være indleveret senest på Afstemningsdagen den 10. februar 1995. På Genforeningsdagen den 15. juni 1995 - 75-året for Genforeningen i 1920 - ville udvalgte manuskripter blive belønnet med priser på fra $2.000 \mathrm{kr}$. til $10.000 \mathrm{kr}$.

Prisopgaven mødte stor interesse. Inden fristens udløb var indkommet $\mathrm{i}$ alt 72 besvarelser svarende til ca. 2.100 maskinskrevne A4 sider.

Bedømmelsesudvalget havde således et meget righoldigt materiale til rådighed, da præmierne skulle fordeles. Men der var ingen tvivl: Førsteprisen blev givet til Marie C. Jessen fra Padborg for en beretning om sit livs historie fra 1920 til i dag.

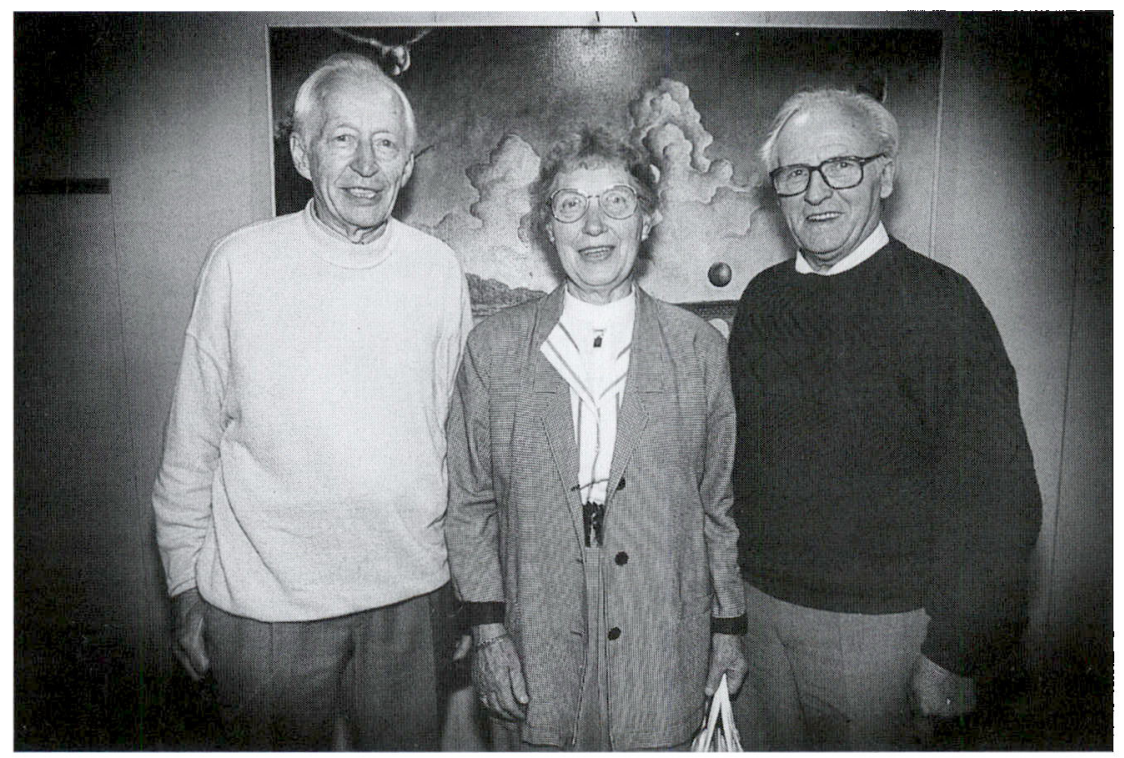

Pramierne i Historisk Samfunds erindringskonkurrence blev overrakt ved en sammenkomst på landsarkivet den 15.juni. Over 100, dvs. en stor del af de mange deltagere i konkurrencen, overvarede sammen med pårorende, at de tre priser blev tildelt (fra venstre) Ludolf Matthiesen, Padborg, Marie C. Jessen, Padborg og Hans Jensen, Lysabildskov. Foto: Karin Riggelsen/Nordschleswiger. 
I 1995 samler Sønderjyske Årbøger sig om vor landsdels historie siden Genforeningen i 1920. Derfor er det naturligt at offentliggøre Marie C. Jessens vindermanuskript i denne sammenhæng. En række af de øvrige manuskripter fra konkurrencen offentliggøres i uddrag sidst på jubilæumsåret i bogen »Sønderjyder - erindringer « siden Genforeningen.

Gennem de 75 år siden 1920 har Sønderjylland - og resten af Danmark - oplevet forbløffende forand'ringer. Vekslende økonomiske konjunkturer, skiftende politiske bevægelser, nationale problemer og afspænding er gået hen over landsdelen. Og altimens er hverdagen for den enkelte blevet en anden.

En del af disse ændringer er afspejlet i Marie C. Jessens fortælling. Den er et personligt dokument, fortællingen om en sønderjyde blandt tusinder andre. Men den afspejler også noget af det almene: hvordan hverdagen blev levet og oplevet og gradvist blev ændret for de mange. Det er en kvinde på landet som taler - dér satte udviklingen ikke de mindste spor.

Forfatteren er født i 1920. I dag er hun nået op i pensionisternes rækker, og tilværelsen som pensionist er anderledes end den var for hendes bedsteforældre for 75 år siden.

Om alt dette fortæller Marie C. Jessen. God fornøjelse!

Danmarks store, verdensberømte digter, ham der måtte gå så gruelig meget ondt igennem, sagde engang: "Livet selv er det dejligste eventyr «. Og det blev det $\mathbf{i}$ sandhed også for den lille, fattige Hans Christian - den grimme ælling, der blev til den smukke hvide svane. Det er nok de færreste, der kan sige som H.C. Andersen, men har vi ikke haft et eventyrligt liv, så har vi dog alle en livshistorie. Når jeg sidder alene og lader tankerne gå tilbage, hvor er der så sket utroligt meget på både godt og ondt $\mathrm{i}$ de mange år fra 1920 og indtil nu.

Helt så langt langt tilbage kan jeg dog ikke huske af den gode grund, at den første gang, jeg så dagens lys, var juleaften kl. 8, 1920, og det eneste lys var skæret fra en petroleumslampe, der stod på et natbord i sovekammeret. Det blev en god indtægt for jordemoderen denne juleaftensdag. Om formiddagen havde hun været ude på en gård for at hjælpe en dreng til verden, og betalingen herfor var $30 \mathrm{kr}$. Far slap billigere. Han skulle betale $20 \mathrm{kr}$. - jeg var jo kun en pige!

Mit barndomshjem, hvor jeg blev født, er »Hesselholt« i den lille landsby Felstedskov ved Aabenraa Fjord. Mine forældre, Anna og Asmus Iversen, var blevet gift kort tid efter at far, såret og afkræftet, var vendt hjem fra krigen 1914-1918. I det blodige slag ved Verdun i Frankrig havde han mistet det ene øje og var nu i tvivl, om han kunne fortsætte som maler, det håndværk, han var blevet udlært i før krigens udbrud. Måske kunne han ikke udføre det tilfredsstillende.

Som barn faldt det mig aldrig ind, at fars øjne ikke var ens, at det ene var af glas. Jeg havde jo aldrig set ham anderledes og tog det som en selvfølge, når han hver aften ved sengetid tog øjet ud og lagde det $\mathrm{i}$ et glas vand. 


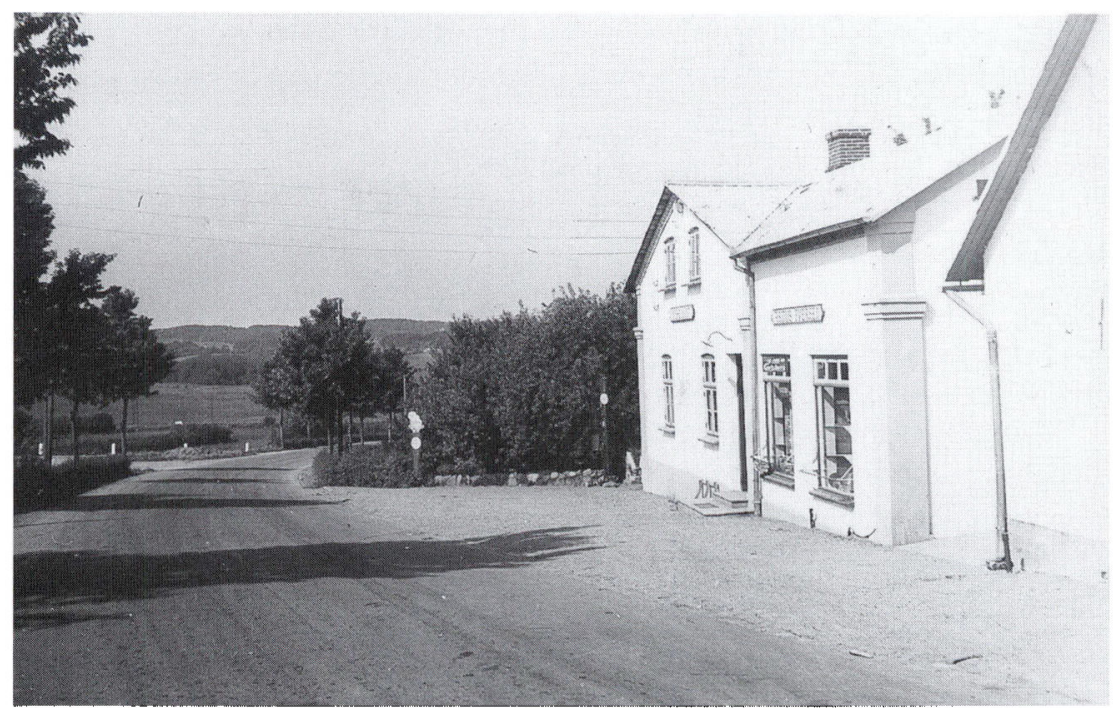

Marie C. Jessens barndomshjem "Hesselholtw. Over vinduerne fortaller skiltet, at her er Asmus Iversens kobmandsforretning. I baggrunden den uanselige benzintank. Foto 1930'erne. Privateje.

Efter mange overvejelser besluttede far at lade malerarbejdet hvile, i hvert fald foreløbig. Men hvad skulle de så leve af, og hvor skulle de bo?

Ved samme tid blev huset "Hesselholt « med en lille købmandsbutik udbudt til salg. Her var måske en mulighed, der var værd at prøve. Hvis ikke andet, så havde de da i det mindste tag over hovedet. Som tænkt, så gjort. De blev enige om at købe huset, og nu var far blevet høker i stedet for maler, og mor var høkerkone. Det kunne der godt laves noget sjovt med, som den gang to naboer stod og snakkede og den ene, uden at fortrække en mine, fortalte at han havde set maleren gå aftentur med høkerens kone - .

Huset, der havde fået navnet »Hesselholt« efter den lange, stejle bakke, hvorpå det var bygget, var i forhold til andre huse på den tid meget stort og rummeligt. Der var højt til loftet, og så var der noget så fint som en stue med en dobbeltdør ud til en stor have, hvorfra der er den skønneste udsigt, man kan tænke sig. Dybt nede til højre fjorden og på den anden side af vejen Felsbæk Mølle med mølledammen.

Jeg tror, at denne molle og Hesselholt en gang har haft en slags forbindelse med hinanden. Det er nøjagtigt de samme store mørkerøde og grønne stenfliser på gulvet i begge køkkener, ligesom de to snørklede jerntrapper, der fører op til hoveddøren, også er ganske ens. Måske har huset været en slags aftægtsbolig til Felsbæk Mølle?

Det var langtfra nogen luksusbolig, mine forældre var flyttet ind i. Alt var 
forfald, blæsten peb ind ved døre og vinduer, ned fra loftet i stuen groede en stor paddehat, og regnen dryppede gennem det utætte paptag. Mest nødvendigt var det at få lagt nyt bliktag på, så måtte de andre reparationer komme efterhånden, når der var tid og penge til det.

\section{Morfar og mormor}

Min morfar og mormor boede også i Felstedskov, en lille km længere oppe ad vejen, så dem kaldte jeg »Bedstefar og Bedstemor ved $æ$ vej«, og min fars forældre var »Bedstefar og Bedstemor i Tumbølk.

Noget af det allerførste, jeg kan huske - jeg har nok været tre år - var, at en dag jeg kom ind i stuen, havde vi fået besøg af »Bedstemor ved $\mathfrak{x}$ vej $\ll$. Hun sad i den gamle armstol i sine lange sorte klæder og snakkede med mor, og da hun fik øje på mig, stak hun hånden dybt ned i lommen på skørtet og halede en femøre frem, sådan en rigtig stor en med hul i midten. Dem kaldte vi et kredbarhjul. Jeg blev helt benovet, da hun rakte mig den og sagde: "No kan do gå ind $\mathrm{i} æ$ butik te far o køef en chokoladehoppaid.« Det var den første mønt, jeg fik i hånden, og jeg syntes den var så stor, så stor. Det var dengang, da man kunne få to tutte bom (poser bolsjer) for 2 øre.

Huset, mine bedsteforældre boede i, havde oldefar selv bygget, endskønt han ikke selv var håndværker. Der var kælder under til opbevaring af brændsel og fiskeredskaber, og om vinteren stod der kasser med kartofler og æbler fra deres egen have. Vinduer og døre havde han også lavet, ja, endda dørhåndtagene.

Bedstefar ved $\mathfrak{x}$ vej var lille og spinkel og smal over skuldrene, men han var fyldt med energi, havde et par spillende brune øjne og et fipskæg, som hans gode ven Heine klippede, når det var ved at udarte sig til fuldskæg. Håret en krans omkring »månen « - blev studset ved samme lejlighed.

Bedstefar gik altid i træsko - »Jyllændertræesk «. med en spids, opadstræbende næse ligesom Hollændertræsko. Når det var vinter og isglat, slog han brodder under træskoene for at stå bedre fast, den samme slags brodder, som blev brugt under hesteskoene. Alligevel gik det galt en dag, da han gik ned ad bakke. Det blæste voldsomt, og han havde medvind, så da den greb fat $\mathrm{i}$ ham og skubbede på, var det umuligt for ham at bremse op. Han løb løbsk og gik på hovedet i vejgrøften; men han faldt blødt, for den var fyldt med sne. Den oplevelse morede han sig tit over, og det gjorde vi andre også. Hvis der kom rigtig meget sne, trak han i gummistøvler eller fedtlæderstøvler. Jeg tror ikke, han ejede et par lædersko, kun kamelhårspusser.

Han havde stærke tænder, brune af skråtobaksovs, og der manglede kun et par stykker, selvom han aldrig havde kendt en tandbørste. Det havde alle andre heller ikke. Tænderne fik lov til at passe sig selv, indtil de var så rådne, 


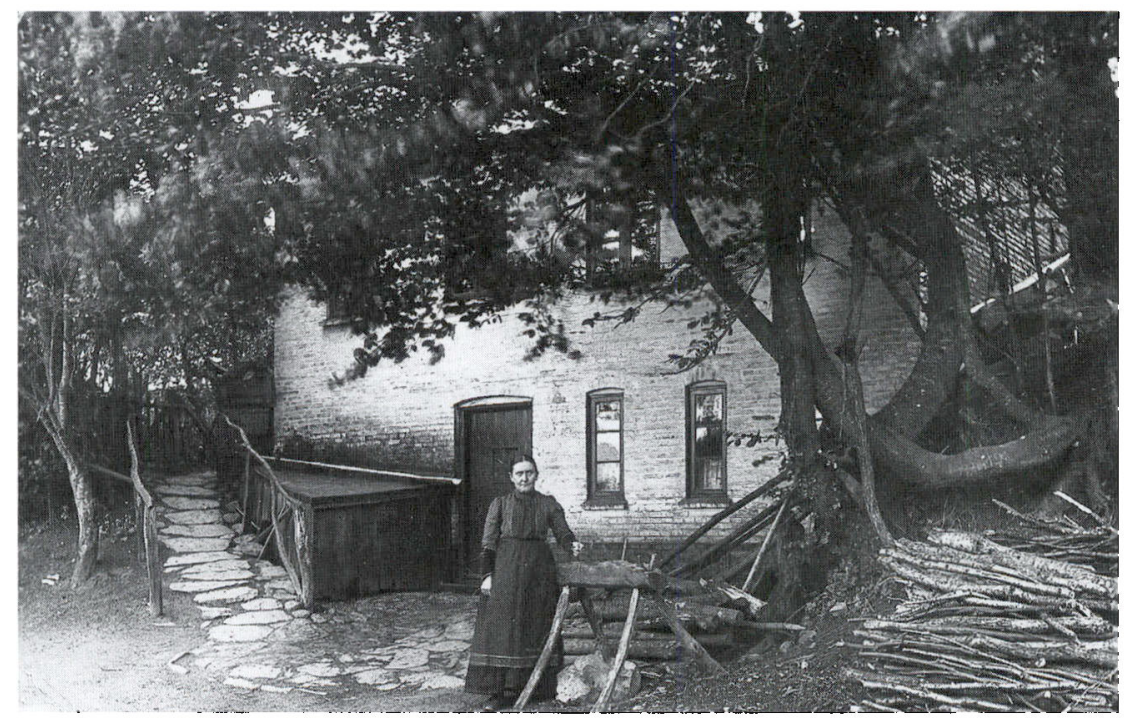

Bedstemor-mormor Marie Hindrichsen foran familiens hus i Felstedskov. Postkort ca. 1890-1900. Foto: Paul Hiller, Hamburg. Privateje.

at de måtte trækkes ud eller så gamle, at de faldt ud af sig selv. Så var det sket, og man var tandløs resten af livet.

Jo! Bedstefar skråede og spyttede også engang imellem. Det hørte sig til, hvis man ville være et rigtigt mandfolk. Inde i stuen ved siden af hans stol, tæt ind til væggen, stod en grå emaljeret spyttebakke, egentlig en gammel kasseret gryde uden ører. Den var halvfyldt med havsand, som blev skiftet en gang imellem, når det var tiltrængt.

I gammel tid lå der et lille savværk nede ved fjorden, og her arbejdede bedstefar. Når han kunne få tid tilovers, tog han ud at fiske, stod op om morgenen kl. 5 og roede »til havs« for at sætte garn ud. Det gjorde gamle Hans også. Jeg tror egentlig ikke, at han var meget ældre end bedstefar, men han virkede sådan, den høje, bredskuldrede skikkelse med det store hvide skæg, sindig i sine bevægelser.

Det tog sin tid, inden han fik sagt noget med sin drævende stemme, hvilket måske skyldtes, at han var meget tunghør og nok ikke altid hørte, hvad han selv sagde. Gamle Hans havde været murer og gik altid med en blå- og gråstribet skjorte uden på bukserne. Dengang syntes vi det så mærkeligt ud, nærmest uanstændigt ... Moden skifter ! Bedstefar, den lille iltre Rasmus, var hans direkte modsætning.

Alligevel passede de godt sammen og havde det hyggeligt, når de stod og redte garn og overgik hinanden $i$ at fortælle krøniker ... jo, de havde sandelig 
været nogle gevaldige karle, da de var unge. De havde hver en lille lav hytte, som gik skråt op fra siderne og nærmest lignede et tag. Hytterne havde de lavet af tang, som vi kaldte det. Det var nu vistnok søgræs, der lå i store banker på stranden.

Som børn fik vi somme tider lov til at krybe ind i bedstefars hytte, hvor der lugtede stærkt af fisk og tjære. Nej! Hvor var det spændende; der var jo halvmørkt derinde. Der stod den lange lave »kredbar« (trillebør), som blev brugt til at transportere garn, hyttefade og andre tunge ting ned til båden. Der var potter med tjære, koste, årer, kork og mange andre mærkelige sager. Når garnene var blevet så slidte og medtagne, at de ikke mere kunne bødes, måtte der nogle nye til. Inden de blev taget i brug, skulle de bejdses eller barkes, som det også hed, og det foregik i en stor fritstående gruekedel nede på stranden. Garnene blev lagt $i$ gruekedlen og overhældt med brun tjære eller beg, og når de havde kogt et stykke tid, blev de taget op og hængt til tørre, hvorefter de nu var stærke og modstandsdygtige overfor saltvandet.

Bedstefar blev ved med fiskeriet til han var langt oppe $\mathrm{i}$ årene, skønt han aldrig havde lært at svømme. At han nemt kunne snuble, falde overbord og drukne, skænkede han åbenbart ikke en tanke. Han havde jo plasket rundt på vandet $i$ en robåd, siden han var dreng. Heldigvis kom han da også altid velbeholden $i$ land.

Der var vel nok fine fisk i Aabenraa Fjord dengang: torsk, sild og makreller og skrubber, sleddinger og rødspæetter så store og tykke, at det tog lang tid at få dem gennemstegt. De var spillevende, når vi fik dem tidligt om morgenen, og hvis man ikke holdt godt fast i gallerne ved slagtningen, gav de et slag med halen og landede på gulvet.

Der var næsten altid så mange fisk $\mathrm{i}$ garnene, at der blev nogle at sælge. Bedstefar havde sine faste kunder. Det var rart med en ekstra skilling til at købe mælk og andre dagligvarer for. De levede nøjsomt, men sundt. Fisk, kartofler, brød og grød var hovedsagen.

Bedstemor har jeg kun et enkelt minde om, for hun døde få måneder efter, at jeg var fyldt tre år. Hun havde i lang tid lidt af Basedow, en sygdom som der dengang ikke var noget middel imod. Den sidste tid, da hun var indlagt på Aabenraa Sygehus, besøgte bedstefar hende næsten hver dag. Gik i træsko de $10 \mathrm{~km}$ til sygehuset, hvor han kun måtte være så kort tid, indtil den strenge oversygeplejerske åbnede døren og sagde: "Besøgstid forbi!« - Ikke eet minut længere fik han lov til at blive. Det var bare med at komme ud af døren og traske den tunge vej hjemad.

Efter bedstemors død i en alder af 54 år blev det ordnet sådan, at bedstefar hver dag kom og spiste middag med os, og han var så præcis, at naboerne stillede deres ure efter ham. Mor gav ham tit et stykke kogt flæsk eller en pølse 
og et fad fedtegrever med hjem, så han havde noget at smøre på brødet. Hver uge bagte hun to store hvedekager, som han naturligvis også fik sin part af. Han behøvede kun at købe kaffe, brød, sukker, margarine, lidt ost og den uundværlige skrå. Det kunne dog hænde, at han flottede sig med en hvidtøl. Mor sørgede også for tøj til ham, vaskede og reparerede. Til gengæld hjalp han far alt det han kunne. Så snart der skulle laves noget ekstra, var han parat lige fra morgenstunden, ja, det skete også, at han tog os på sengen.

\section{Farfar og farmor}

Bedstefar og bedstemor i Tumbøl besøgte vi kun et par gange om året. Det var temmelig langt at cykle ad en bakket grusvej. De to og fars faster boede på aftægt hos onkel Christian og hans kone og havde en lille stue og et soveværelse til rådighed. Fasters soveplads var alkoven i stuen.

I bedstefars og bedstemors soveværelse var der henne i det ene hjørne et skab, som blev brugt til toiletrum, og det blev også benyttet af faster. Selve toilettet var en gammel armstol, hvor der var savet et rundt hul i sædet, og herunder stod en spand. Et låg blev lagt over, når det nødvendige ærinde var besørget. Alle havde før i tiden en natpotte stående under sengen, for der var langt at gå i mørke enten ud til lokumet eller kostalden. Elektrisk lys havde man jo heller ikke. Men de tre gamle mennesker var så stive i benene, at de ikke kunne benytte natpotten, og derfor var det da meget godt med »toiletrummet«!

Tante Tidde stod for husholdningen, og de spiste alle ved samme bord. Vinteraftener samledes alle $\mathrm{i}$ den lille, lavloftede aftægtstue, fem voksne, tre børn og to jagthunde. Der var varmt og trangt, lugtede af hund og lampeos, luften var tæt og trykkende.

Fars faster var hele byens faster og blev aldrig kaldt andet. I sin ungdom var hun en meget køn pige og blev forlovet med en gårdmandssøn, men hun var ikke god nok i hans forældres øjne. Nej! Deres søn skulle sandelig ikke giftes med en pige under sin stand, så det bryllup blev der ikke noget af. Dette hovmod fra forældres side gjorde, at mange unge mænd og piger blev ulykkelige, fordi de ikke måtte få den, de holdt allermest af. Fornuftsægteskaberne, hvor det frem for alt drejede sig om penge og udstyr, førte sjældent til noget godt. Faster giftede sig aldrig, og når hun blev spurgt, hvordan det dog kunne være, svarede hun altid: „Den jeg ville have kunne jeg ikke få, og dem jeg kunne få, ville jeg ikke have«.

Hun blev en god hjælp for bedstemor, der i en tidlig alder blev så plaget af ledegigt, at hendes hænder og fødder var helt krumme, og hun kunne kun gå i sko, som Onkel Skomager, Hans Langendorff, syede til hende. Han var gift med min faster Anna, en livlig, akkurat og pertentlig lille dame. Hendes cykel var parkeret $\mathrm{i}$ stadsstuen, og når hun havde været på cykeltur, blev den 


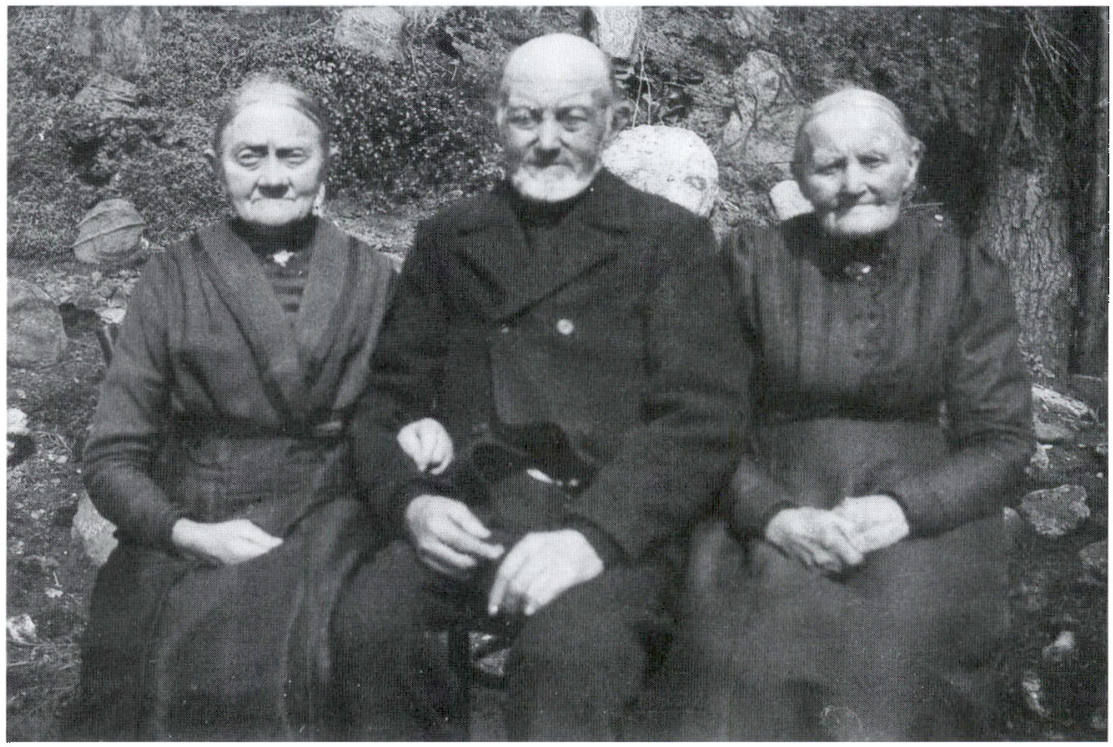

Farfar og farmor og faster fra Tumbol. Fra venstre farmor. Marie Cathrine Iversen, farfar Christian Iversen og fars faster Cathrine Iversen. Foto ca. 1930. Privateje.

pudset og set efter i alle ender og kanter, inden den igen indtog sin fornemme plads.

Lune havde hun også. Da hendes Hans vendte hjem fra krigen og havde mistet den yderste lille næsetip, sagde hun, at nu havde han da endelig fået snuden hvæsset. Det var sikkert et udbrud af overstrømmende glæde over, at han var sluppet så heldigt. Onkel Skomager, der var bred med rund mave, havde altid sit skødskind på, også om søndagen og hvis de havde gæster. Ellers frøs han på sin mave, påstod han.

Bedstefar i Tumbøl var en høj stovt skikkelse med hvidt hår og skæg, havde milde øjne og et varmt smil. Han var dygtig til regning og spurgte gerne, om jeg havde løst opgaven i »Ugens Nyheder«. Jeg var ikke så lidt stolt, når jeg kunne svare ja. Det var sjældent at se ham uden den mørkeblå kasket. Enten han var ude eller sad i stuen, kasketten blev på sin plads lige fra morgenstunden til sengetid; måske dog lige undtagen i den værste sommervarme.

Han skråede ikke som bedstefar ved $\mathfrak{x}$ vej, men han ville gerne spille kort, og så spillede far og mor 66 med de to bedsteforældre. Det blev dog som sagt kun til et par gange om året. Bedstemor spillede ikke kort, hun sad og strikkede hoser med sine gigtkrogede fingre alt imens hun snakkede med faster, som ikke mere kunne holde på strikkepindene, fordi hun rystede meget på hænderne. 
Bedstemor nåede kun bedstefar til skuldrene, hun var rank med en slank talje. Håret var redt med midterskilning, stramt tilbage og dækkede slet ikke noget af ørerne, der var temmelig store. Hendes øjne var matte. Hun havde nemlig fået grå stær og blev ikke opereret, fordi det dengang var en stor operation med risiko for, at det ikke ville lykkes. Altid var hun rolig og velafbalanceret, og hun sagde ikke meget. Jeg var som barn meget imponeret af, at hun ikke var spor bange i tordenvejr, og jeg havde stor respekt for hende.

Hun havde sans for at se alt det smukke i naturen, fra det mindste til det største, og glæde sig over det. At tegne og male var hendes store interesse, så længe hun endnu kunne se til det, og når hun så et fint landskab, sagde hun altid: "Hvor kunne det blive et smukt billede«.

Desværre kan der ikke udrettes ret meget med et ark almindeligt hvidt papir, en blyant og en smule vandfarve. Hvornår skulle hun også få tid tilovers til det hun allerhelst ville? Det var ganske utænkeligt, at en kone på landet kunne finde på sådan noget vås. Hendes pligt var at passe hus og børn og hjælpe manden med arbejdet både inde og ude. Alt andet var unødvendigt. Mange talenter er gået tabt på grund af denne indgroede anskuelse.

Bedstemors interesse for at tegne og male gik $\mathrm{i}$ arv til far og videre til mig. Heldigvis har tiderne forandret sig. Nu kan jeg få lov til at glæde mig over denne dejlige hobby uden at nogen bliver forarget af den grund.

Det var blevet en tradition, at de tre gamle fra Tumbøl kom og besøgte os på Hesselholt 1.juledag og blev til 2.juledag om formiddagen. De kom kørende i lejebil, og det var meget dyrt, hele $4 \mathrm{kr}$., men da det kun var denne ene gang om året, kunne de nok tillade sig en sådan luksus. Privatbiler var der ikke mange af; kun præsten, lægen, dyrlægen, sognerådsformanden og et par andre rangspersoner ejede et sådant køretøj.

Det var langtfra hver dag, at en bil viste sig på landevejen, og det var noget af en oplevelse, når en sort, højbenet Ford med »Cykelhjul« pustende og stønnende kravlede op ad bakken, eller når den kom trillende om hjørnerne og udstødte sit YA! YA! til skræk og advarsel for fodgængerne, der flygtede over i vejsiden, indtil uhyret var passeret. Bilen blev startet med håndsving, og det var ikke hver gang, det lykkedes for chaufforen at springe ind og få startet, inden den igen gik i stå. Med tiden blev bilerne mere moderne; der var nu også kommet Chevrolet $\mathrm{i}$ handelen, både mørkeblå og vinrøde. Jeg kommer uvilkårligt til at tænke på det hav af biler, vi har i dag ... en kolossal udvikling.

Nå! Som sagt kom vore gæster flot kørende med en fart af $40 \mathrm{~km}$ i timen; det var rigtignok noget andet end at gå. Lige så snart bilen standsede udenfor døren, var vi der allesammen for at tage imod dem, også bedstefar ved æx vej. Det tog sin tid, inden de blev viklet ud af de mange tæpper, der var nødvendige for at holde varmen i den kolde bil. Bedstefar var i sit tykke uldne sæt tøj og 
en ligeså tyk ulden overfrakke samt den uundværlige kasket. De to damer kom også i tykke frakker og havde kapothat på hovedet, sådan en sjov tingest, der nærmest lignede en stivet kyse, der gik højt op foran og blev bundet under hagen med en stor sløjfe af et bredt, sort silkebånd. Deres langærmede kjoler, også sorte, gik helt ned til gulvet og højt op i halsen. De gik begge med stok.

Mor havde fyret godt i kakkelovnen, og middagen var parat. Snart sad vi alle omkring spisebordet for at nyde den gode mad; frikadeller, kartofler, brun sovs og stuvet hvidkål med syltede kvæder og asier som tilbehør.

Når vi havde besøg fra Tumbøl, serverede mor altid bøf, frikadeller eller hvidkålsbudding, fordi det var let at tygge. Både bedstemor og faster var tandløse, og bedstefar havde heller ikke for mange at prale af. Efter middagen, mens vi hjalp mor med at vaske op, sad de andre og snakkede og fik sig et lille nik ind imellem.

Jeg glemmer aldrig den jul, hvor vi for første gang havde fået radio. I Felstedskov var det kun lærerens, der havde en foruden os, og han hjalp far med at få den installeret. For os var det som et mirakel, da den første skrattende lyd kom ud af højttaleren. Radioen tog flere stationer på een gang; det var så godt som umuligt at indstille den så nøjagtigt, at nabostationen ikke snakkede med.

Radioen var en Remington og havde form som en stor cigarkasse, hvor låget kunne løftes op, og det var også nødvendigt, for inde $\mathrm{i}$ kassen sad løse spoler, som skulle byttes om, hvis man ville have en anden bølgelængde. Højttaleren hed Brown og stod for sig selv. Det var først senere, der kom apparater med indbyggede højttalere. Een gang om måneden blev akkumulatoren ladet op hos en elektriker, og hvert halve år skulle der købes et nyt anodebatteri.

Når vore kære gæster havde holdt deres middagshvil, ville de gerne høre julegudstjeneste i radioen kl. 2. De satte sig godt til rette i stolene og lyttede andægtigt til præstens prædiken, da faster pludselig rejste sig, gik hen til radioen, løftede låget op og kiggede ned i kassen. Hvad gik der dog af hende? ... Så kom forklaringen: »Jo, æ vild da så gjern se æ præst«.

Alle brast $\mathrm{i}$ latter; hvor kunne hun da få sådanne tåbelige forestillinger fra? Ingen anede jo, at der engang med tiden ville komme det, der hedder fjernsyn. Hvis faster havde levet i dag, kunne hun have fået både præsten, menigheden og kirken at se.

Anden juledag kom fars bror, onkel Hans, med hestevogn og hentede sine forældre og faster. Onkel Hans havde været malermester, men ville prøve noget andet og blev landmand.

Den store gård "Stenneskær« var blevet udstykket til husmandsbrug, og onkel Hans og tante Ingeborg købte et af disse, der dog var lidt større end de andres, fordi det var stamparcellen. De havde fire piger og en plejesøn.

Far, der var den yngste af søskendeflokken, havde lært malerfaget af sin bror. 


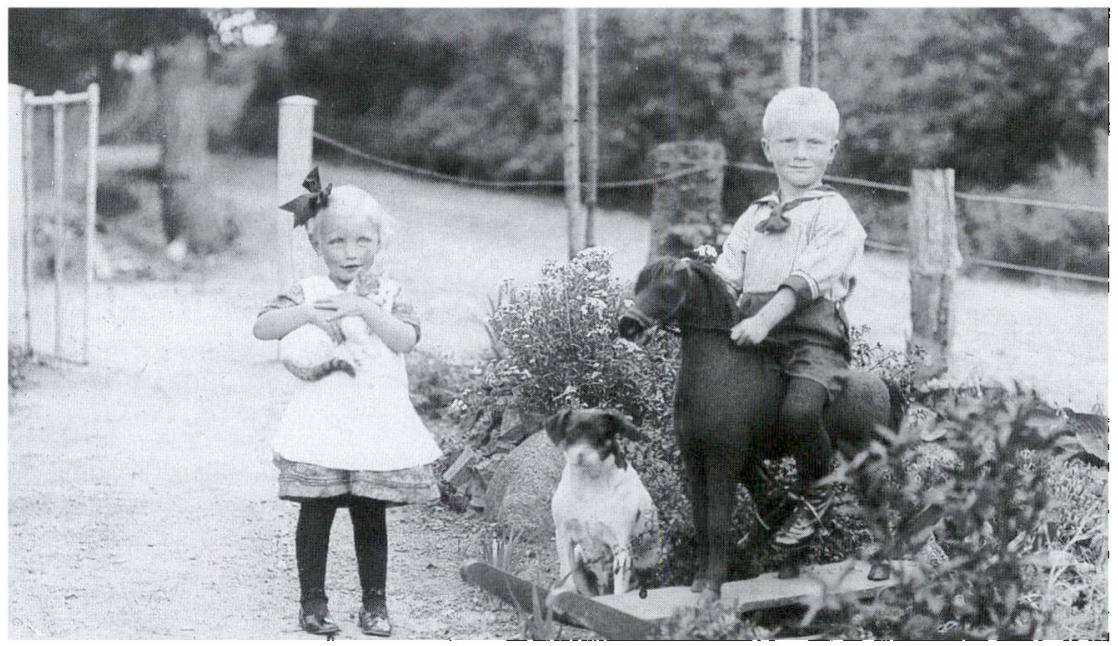

Barndomsidyl i Felstedskov. Marie og nabodrengen Hanni pd̊ den fine gyngehest. Foto: juni $1924 i$ privateje.

En anden bror, Peter, fik lungebetændelse, da han deltog i krigen, og blev sendt hjem på sygeorlov. Lungebetændelse var en alvorlig og frygtet sygdom. Det gjaldt liv eller død. Den blev også kaldt »den unge mands fjende og den gamle mands nådige ven «. Onkel Peter stod ikke krisen igennem. Han døde hjemme hos sine forældre. Penicillin blev først opdaget og anvendt mange år senere.

\section{Barndomsleg og venner}

Der var ikke mange huse lige i nærheden af Hesselholt, men endnu højere oppe på bakken ligger et lille hus, hvor landsbybørnene engang for længe siden havde gået i skole. På grund af husets beliggenhed blev det i spøg kaldt for "Højskolen«. Her boede Lorenz og Frida med deres dreng, der også hed Lorenz, men altid blev kaldt Hanni. Han var godt et år ældre end jeg, og vi legede sammen hver eneste dag helt fra vi var små.

Hanni havde en gyngehest, og det var ikke bare sådan en af træ. Nej, den var udstoppet og havde facon, farve og hale som en rigtig hest med seletøj og det hele. Jeg havde en dukke med langt ægte hår, og den kunne lukke øjnene op og i, men jeg brød mig slet ikke om at lege med hverken den eller dukkevognen. Det var da meget sjovere at finde på noget andet, og der var næsten ingen grænser for, hvad Hanni og jeg kunne finde på.

Som små bagte vi tit »sandkager«. Vi fik hver en urtepotte og en slat vand med ud til den sandstak, der lå bag ved »Højskolen«. Sanddejen blev rørt sammen, fyldt i urtepotterne og vendt med et rask tag. Snart stod der mange 
kager på rad og række. En dag slap vandet for tidligt op, og vi måtte ikke få mere at plaske med. Hanni fandt dog straks på råd; han tissede i sandet, og bagningen kunne fortsætte.

En anden dag gik det værre. Han havde fået et massivt hjul af træ til at trille med, og da vi altid holdt sammen og delte alt med hinanden, skulle jeg selvfølgelig have halvdelen, så vi begge havde et trillehjul ...! Han lagde hjulet op på huggeblokken, og jeg skulle holde godt fast, mens han tog øksen og huggede til.

Et sekund efter hang det yderste led af min højre ringfinger kun fast ved en hudlap. Det var søndag, og vi havde familiekomsammen. Alt blev forvirring, da jeg skrigende og blødende kom løbende hjem. Mor fik $i$ hast et bind viklet omkring hånden, men blev dårlig tilpas og besvimede. Far tog mig på cyklen og kørte så hurtigt han kunne til lægen i Felsted.

Han må have været meget dygtig, Dr. Ruge, for han fik fingeren samlet med sting og klemme, så den ikke engang blev stiv. Kun et ar minder mig nu om den gang vi troede, det kunne lade sig gøre at trille med et halvt hjul.

Omme bag laden ved mit hjem var en hønsegård med en halv snes høns og en hane. Her gravede vi i skrænten, byggede huse og havde det herligt. Geden græssede lige i nærheden, men den holdt vi os i ærbødig afstand fra, skønt den altid var ganske fredelig. Jeg fik gedemælk de første år; hvordan det smagte, kan jeg slet ikke huske.

Hannis mor var fra Langballigau i Tyskland, ikke ret langt fra grænsen, og hun talte udmærket dansk. Det foretrukne sprog i hjemmet var dog tysk, og det kom næsten af sig selv, at jeg både forstod og kunne tale det. Børn lærer hurtigt. - Det var nok naturmetoden! En anden ting er, at jeg glemte det lige så hurtigt igen, da jeg kom i skole og legede med andre børn, der naturligvis kun talte dansk.

I maj 1924, en måned efter at bedstemor ved æ vej var død, fik jeg en søster, som fik navnet Christine. Vi lignede slet ikke hinanden, hverken af sind eller skind, som man siger. Hun var rund og buttet og har brune øjne ligesom mor havde. Jeg ligner min far i et og alt. Som barn og ung havde Christine langt kønnere ansigt end jeg. Jeg stod sommetider ved spejlet, trykkede på min næse og ærgrede mig over dens facon. Den var for lav, syntes jeg, og havde en tendens til at vende opad.

Da vi søstre var og er så forskellige, blev vi selvfølgelig tit uenige og kom op at skændes. Hvis Hanni og jeg kunne komme godt af sted med det, stak vi af uden at tage Christine med. Det blev dog bedre, da vi blev lidt ældre og mere fornuftige. Nu legede vi helt godt sammen alle tre og fik lov til at gå til stranden, hvor vi havde det herligt med at bygge sandslotte pyntet med muslingeskaller. 
Vi flettede kurve af noget bredbladet lysegrønt, nærmest gråligt græs, som vi kaldte skæregræs, fordi det skar dybt ind i fingeren, hvis vi ikke passede på. Mon ikke det har været marehalm? I strandkanten samlede vi sten, mange forskellige, nogle med et hul, som der kunne trækkes snor igennem, og nogle helt flade, som var gode til at slå »smut « med. Og der var de hvide eller teglstenrøde, der kunne bruges til at skrive med. Sommetider klatrede vi op ad de høje, stejle skrænter, æ Havkløvt, og kurede ned på enden eller maven.

På nogle af skrænterne groede hjertegræs, der var så smukt med de bittesmå dinglende hjerter. Der var lilla blomster, som vi kaldte hyacinter. Dem var vi lidt bange for at plukke; vi troede de var giftige. Overalt vrimlede det med følfod, rævehaler og padderokker, store og frodige i den lerede jord. Nede på stranden i nærheden af hvor bedstefars båd var fortøjet, stod en mægtig kampesten, som var flækket fra øverst til nederst af et voldsomt lyn. Man kunne lige stikke en hånd ind mellem de to halvdele.

\section{Mors butik}

Den butik, far og mor havde fået indrettet, var kun et rum med to små vinduer, eet ud til vejen og eet til gårdspladsen ved siden af indgangsdøren med den gamle butiksklokke.

Hvordan butikken ellers var indrettet kan jeg ikke mindes, men jeg ved, at vi fik elektrisk lys, da jeg var fire år. Det var vel nok noget andet end petroleumslampen. Om aftenen blev det lige så lyst som midt på dagen, blot der blev trykket på en kontakt. $\mathrm{Nu}$ behøvede mor ikke mere at sige: "Pas godt på at du ikke kommer så nær til lampen, at den vælter og tænder ild i huset«.

Efter krigsårene kunne det $\mathrm{i}$ begyndelsen være svært at skaffe de varer, kunderne havde brug for. Heldigvis var ingen fordringsfulde. De havde gennem mange år fået lært at nøjes med lidt.

Ingen af mine forældre havde nogensinde prøvet at stå i forretning, men det gik alligevel meget godt. Altid var de venlige over for kunderne og kunne snakke med om alt, hvad der betød noget for hver enkelt. Hvordan det gik med roehakningen, eller om de snart havde fået høsten i hus. Om lille Peter skulle begynde at gå i skole efter påske, og Didde skulle da vist snart konfirmeres. Plagede gigten slemt i dette ruskvejr, var de sluppet for influenza ? ... Jo, det betyder meget at interessere sig for andres ve og vel.

Regnskabet voldte ingen kvaler; det tog far sig af om aftenen, når mor sad med den evindelige stoppekurv, der aldrig nåede at blive tom, før der igen var strømper med hul på hæl og tå. Disse heluldne, hjemmestrikkede strømper var varme, men ikke slidstærke. 
Fars maler- og glarmesterforretning

Mor var den, der mest passede butikshandelen, for far var så småt begyndt at gå $\mathrm{i}$ gang med sit gamle håndværk. Malerværkstedet blev indrettet $\mathrm{i}$ den ende af laden, der vendte ud mod vejen. Her var mest lyst, der var god plads, og der var en dobbeltdør, hvilket var nødvendigt, når der skulle en fajtong (stadsvogn) ind for at blive malet og lakeret. $Æ$ fajtong blev egetræsmalet, som far kaldte det, et arbejde som ikke blev færdigt sådan lige med det samme. Hjulene blev eet ad gangen anbragt på et redskab, så de var nemme at dreje rundt, når egerne blev malet. Til sidst kom prikken over i'et: udsmykningen, de fine, tynde gule eller blå streger.

Langs den ene væg i værkstedet stod en lav reol med store og små skuffer til tør farve. Alle disse kulører, som jeg aldrig blev træt af at se på, især den ultramarine, denne smukke dybblå farve. Reolen bar præg af at have været brugt i flere år. Der var mærker og pletter af spildt maling overalt. Det havde nu ingen betydning, for det hændte også at far spildte lidt engang imellem. En gammel vægt stod der også, lige så tilklistret. Ovenpå reolen var et virvar af blikdåser og flasker med terpentin, benzin, gulvlakfernis, brun bejdse, shellak, kit, tørrelse, sandpapir og mange andre ting.

Sommetider kom nogen og manglede maling til en vogn, en båd eller måske til døre og vinduer udvendig. Far rørte den tørre farve samme med linolie, indtil den blev tilpas tyk og jæun uden klumper, og for at det ikke skulle vare alt for mange dage, inden den blev tør, tilsatte han noget »tørrelse«, så meget som når man kommer fløde i en kop kaffe. Han købte en hel tønde linolie ad gangen. Spunsen blev slået ud og en hane anbragt $\mathrm{i}$ stedet for, hvorefter tønden blev anbragt på en træbænk. På gulvet stod en spand vand, hvor penslerne blev sat i blød, så de ikke blev tørre og stive til næste dags arbejde.

Far gik altid i kittel til hverdag, den brune i butikken og den hvide ved malerarbejdet. Hvid er nu så meget sagt; han havde nemlig for vane at tørre fingrene af $\mathrm{i}$ kittelen, skønt der altid var en dertil beregnet klud $\mathrm{i}$ lommen. Efter endt arbejdsdag gjorde han alt parat til den næste dag.

Glarmester var han også. Den firkantede glarkasse var lavet af træ med remme af stærkt, stift læder og blev spændt på ryggen som et tornyster. Fyldt med glas og kit var den meget tung.

Jeg har tit undret mig over, at han kunne slæbe alt det på cyklen. Glarkassen på ryggen, en kurv med maling og en tapetbog i bagagebæreren og en spand limfarve hængende på styret. Hvis han også skulle have trappestigen med, blev den bundet fast langs ad cyklen, og så var han nødt til at gå, somme tider flere $\mathrm{km}$. Der blev sendt bud efter ham fra en stor del af sognet, han lavede et godt stykke arbejde for en rimelig pris. 


\section{Vask og rengoring}

Mor havde nok at gøre med huset, butikken, den store have og os to piger. Tante Trino, som jeg kaldte min moster, var også i gang fra tidlig morgen til sen aften. Der var ikke noget der hed et bestemt antal arbejdstimer, ligegyldigt hvad man var beskæftiget med. Efter at tante Trino var rejst, fik vi en fjortenårig tjenestepige til hjælp, og da hun rejste efter et par års forløb, afløstes hun af en anden fjortenårig. Dette gentog sig indtil jeg blev konfirmeret og kunne hjælpe til overalt derhjemme.

En gang om måneden havde vi en kone til hjælp ved storvasken. Alma hed hun og var fra Berlin, høj og rank og med et hår, der næsten var blåsort. Hun havde fået lært at tale dansk, dog ikke så godt som Hanni’s mor. I to dage blev der vasket, og det var en ordentlig bunke tøj, der skulle skrubbes på vaskebræt, koges to gange i gruekedlen, skylles flere gange og vrides med hænderne.

Når det gjaldt lagner og dynebetræk, tog mor og Alma fat $i$ hver ende og blev ved med at dreje, til tøjet var som et hårdt reb. Det gjaldt om at få så meget vand ud af det som muligt, inden det blev hængt ud på tørresnoren. Bedstefar ved æ vej fik selvfølgelig også sit tøj med i vask, men det kneb med at få det tykke undertøj med lådden vrang helt hvidt. Mor havde sit mas med at få ham til at skifte noget tiere.

De to vaskekoner stod og skrubbede op og ned på vaskebrættet i en zinkbalje, en galvaniseret balje, der stod på en stol. Vi havde også en "Toballe«, en træbalje med buede ben. Derfra stammer udtrykket »Toballeben«, når en person var hjulbenet.

Dagen før storvasken var tøjet blevet sat i blød med Henkel Blegsoda, og det mest snavsede tøj blev smurt ind med brun sæbe og lagt i en "IMI«opløsning. Herunder hørte også de tomme hvedemelssække fra butikken. Både de og sækkene fra havregryn og salt blev sprættet op og kogt i Persil Vaskepulver. De to sidstnæunte syede mor viskestykker af, for de havde røde og blå striber ved kanten. Hvedemelssækkene blev brugt til pudebetræk, særke, natkjoler o.s.v.

Arbejdet gik med liv og lyst. Både Alma og mor kunne synge, ligemeget om det var dansk eller tysk. Skamlingsbanken, Donauvalsen, Es war im Böhmerwald, Hils fra mig derhjemme, Trink, trink, Brüderlein, trink, Sejle op ad åen og mange, mange flere ... det kunne man da kalde et potpourri.

Ude under halvtaget havde far og bedstefar fra Tumbøl støbt en cementbeholder til opsamling af regnvand til vask og rengøring, og det var en stor lettelse, for vandet løb gennem et rør ind $\mathrm{i}$ vaskerummet. Alt vand til husholdningen blev hentet ved en pumpe helt nede $i$ den anden ende af haven. Først mange år senere, da far havde været til købestævne i Fredericia, fik vi eget vandværk. 
Dyrene

I den stråtækkede lade var der foruden malerværkstedet en lille lo, et kulrum, to svinestier og en kobås. Geden var efterhånden kommet temmelig højt op i årene og blev nu skiftet ud med en ko. Det var dejligt, den gav mere mælk, end vi selv kunne bruge. Resten blev leveret til mejeriet.

I nabolaget havde fem bønder i fællesskab købt en mejerivogn. Vognladet var firkantet, fladt og med et rækværk omkring, så der var plads til mange spande, også til vor enlige spand. Bønderkarlene skiftedes til nogle dage ad gangen at køre mælken til mejeriet $\mathrm{i}$ Felsted og få skummetmælk og lidt kærnemælk tilbage. Skummetmælken var endnu lunken, når den kom fra mejeriet, og mor brugte den altid, når der skulle bages franskbrød. Kærnemælken var meget bedre end den, man nu køber i forretningerne. Der kunne godt svømme små smørklatter ovenpå.

Om sommeren gik koen og græssede på den halve tdr. land, der hører til Hesselholt. Marken er nærmest en skrænt, der skråner så meget, at den kun kan bruges til græs. Jeg var langtfra begejstret for den ko, da jeg blev noget ældre. Når far om sommeren var på arbejde, var det min bestilling at trække den ud om morgenen og ind om aftenen og malke to gange om dagen. Lunefuld var den, sparkede og ville ikke stå stille.

Om vinteren skulle den fodres og vandes. Det sidste var noget af et problem. Hvis ikke den fik serveret lunkent vand, rørte den det overhovedet ikke. Om den fik tandpine af det kolde vand eller bare ville gøre sig kostbar er ikke nemt at vide. I den periode, hvor den ikke gav mælk, hentede vi hver aften 21 mælk á 15 øre ved stalddøren hos den nærmeste bonde.

Roer, hø og halm til vinterfodringen havde vi jo ikke, men det skete somme tider, at far fik det leveret af en bonde, der skyldte penge for købmandsvarer. Tiderne var dårlige, og for bonden betød det ikke så meget, om han havde et læs foder mere eller mindre. Hellere det end undvære rede penge.

I den ene sti gik en griseso og $i$ den anden et par fedesvin.

En hund havde vi også, Terry hed den, og den var vi meget glade for. Den måtte dog kønt blive hjemme, når vi en søndag eftermiddag sidst på sommeren havde vor årlige nøddetur. Terry måtte ikke komme med til skovs og jage rundt efter dyrene.

\section{Skolegang}

Efter min 6 års fødselsdag juleaften begyndte jeg i skolen lige efter påsken 1927. Skolen var lille med kun eet klasseværelse, der egentlig var en stor stue i beboelseshuset. Der var gennemsnitlig 20-25 elever i alt i skolen og een lærer, der var dygtig og ville have, at vi skulle bestille noget og lære så meget som muligt. Jo, vi var heldige, at vi havde fået lærer Petersen. En gang var elevtallet 
helt nede på atten. Det kunne ske, at der et år slet ikke var nogen nybegyndere. Til gengæld kom der det ene forår fem børn i skole på een gang. Det var en sjældenhed.

Inden man kom ind i selve skolestuen var der en forstue, hvor der til højre hang en knagerække til vort overtøj, og nedenunder stod en lang bænk, som vi kunne sidde på i frikvarteret og spise vor medbragte rundtenom. Om vinteren sad vi og krøb sammen for at holde varmen, men trods alt var det dog bedre end udenfor. At blive inde i skolestuen var forbudt; der skulle luftes ud.

I den modsatte side af forstuen var en reol med een rakke rum til tornystre og to rækker til træsko. Vi havde alle skiftesko med, »Tøjpusse«, med såler af cykeldæk. De blev købt hos en mand som kom omkring og solgte ved dørene. De fineste og dyreste var syet af broget jernbanefløjl og de billige af mørkeblåt uldstof. Prisen var hhv. 1,60 og 1,20 kr. pr. par.

I skolestuen var der på hver side af midtergangen en række siddepladser, bænk og skrivepult ud i eet med plads til to eller tre elever. Bordpladen skrånede lidt og var dobbelt, så en klap kunne trækkes frem. Ved den bageste kant var en fordybning til blækhuset, der var af tin og blev lukket op med et skydelåg, og der var en rille til blyant, griffel, viskelæder og penneskaft. Pennene lå $i$ en lille blikæske sammen med en klud til at tørre dem af med efter brug.

Det var slet ikke så let at få lært at skrive med blæk. Hvis pennen blev dyppet for meget, kunne der nemt komme en klat på papiret, og det var noget af en katastrofe. Penalhuset, bøgerne og tavlen lå på en hylde under pulten. Mit første penalhus var af træ med skydelåg. Senere fik jeg et af læder med tryklåse. Hverken plastic eller lynlås var opfundet.

Tavlen havde linier på den ene side og kvadrater på den anden. I trærammen var et hul, hvortil viskekluden blev bundet fast med et stykke sejlgarn. Mor syede altid viskekluden som en kort, tyk pølse af en rest vandsugende stof. Det var billigere end en svamp. Vand til at gøre tavlen ren med havde vi i en lille flaske, der kunne stænke, f.eks. en tom brillantineflaske. Tavlen var i brug hver eneste dag til både regning og skrivning. Sikken masse papir der blev sparet!

Diktat og stil blev først skrevet med blyant i et kladdehefte og derefter med blæk i en bog med stift bind. Nogle af bøgerne har jeg stadig og kigger somme tider $\mathrm{i}$ dem om aftenen, når jeg sidder alene. Minderne fra skoletiden dukker op. Det er som at blive ført tilbage til en tid, hvor alt var helt anderledes.

For enden af den lange gang i skolestuen stod katederet med en stol. Bagved på væggen hang en stor, sort tavle. En anden stod på gulvet og her kunne landkortet anbringes i geografitimerne. På væggene hang billeder af Ingemann, Oehlenschlæger, Grundtvig, Thorvaldsen og Bjørnstjerne Bjørnson.

Tænk en gang, vi havde også et bibliotek, et gammelt skab med mange hylder, hvor bøgerne stod på rad og række. Ikke tilfældigt; de var sat rigtigt i 


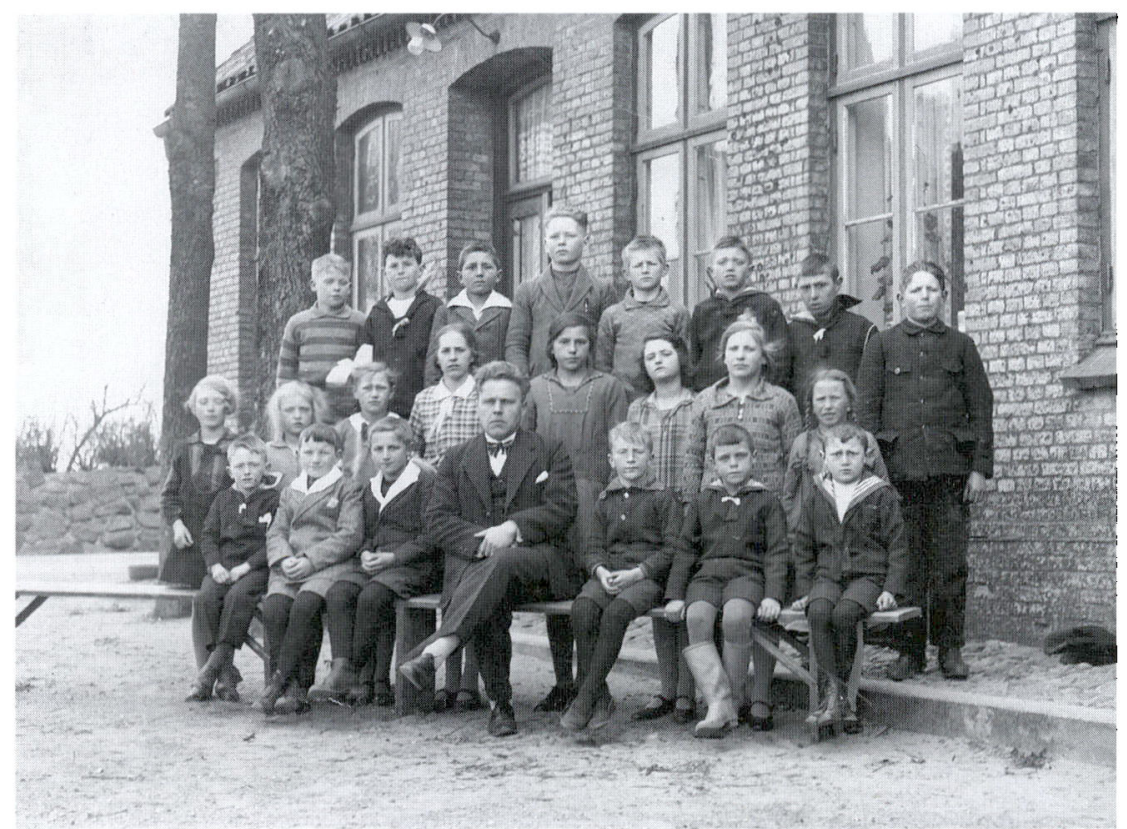

Den enklassede skole i Felstedskov foran skolens larerbolig. I midten lurer Hans Petersen. Marie står yderst til venstre i midterste rakke. Foto 1929 i privateje.

system. Hvor jeg dog glædede mig til hver anden fredag, når der kunne byttes bøger.

Pigebøger brød jeg mig ikke om, de var for kedelige. Nej! - Kaptajn Grants Børn, Nybyggerne i Kanada, Børnene i Nyskoven, Jorden rundt i 80 dage, Urskovens Søn, Frændeløs o.s.v. Alle de herlige klassikere, Gjøngehøvdingen ikke at forglemme. Når jeg kom hjem og kastede mig over sådan en bog, glemte jeg alt omkring mig. Mor skændte; jeg kunne da godt gøre noget gavn efter skoletid.

En af de allervigtigste ting i skolestuen var den store, runde tykmavede kakkelovn, vor allerbedste ven i de lange hårde isvintre, vi havde dengang. Det første læreren gjorde om morgenen, efter at vi havde sunget morgensang og bedt morgenbøn, var at sende en af de store drenge ud i udhuset efter kul, koks, et par briketter og noget optændingsbrænde, så der kunne komme gang $i$ vor tykmavede ven. Briketterne blev lagt øverst. De kunne ligge meget længe og gløde og holde ilden ved lige.

Som sagt var lærer Petersen dygtig til at undervise, og det foregik på den måde, at når de store sad og skrev stil eller havde regneopgaver, hørte han de små i læsning og salmevers. Og de lærte nogle sange, mens han spillede på 
violin. Vi lærte meget udenad, lange salmer, Luthers lille katekismus fra ende til anden, fædrelandssange og nogle digte fra en bog, som vi kaldte Flagbogen, fordi der var et stort Dannebrog på omslaget. Det digt, jeg husker bedst, er "Søren Kanne« af Steen Steensen Blicher:

"Det blæste en storm udi Kattegat,

de bølger de ginge så høje.

Så mangen stolt sømand den samme nat

for sidste gang lukked sit øje«

Der er 22 vers, og vi lærte dem alle.

Vi sang af den blå sangbog, som altid blev brugt ved sammenkomster $\mathrm{i}$ Sønderjylland og ikke var kendt i det øvrige Danmark. Jeg har et eksemplar med gotiske bogstaver fra 1908, foruden den jeg brugte i skolen. Der er så mange skønne sange, som jeg synes burde have deres plads i Højskolesangbogen, i stedet for de udenlandske som mange ikke kan forstå alligevel. Hvad skal vi med dem, når vi har så stor en sangskat på vort eget sprog?

Det var et lille sidespring, - men tilbage til skolen!

Efter frikvarteret blev rollerne byttet om, så det nu var de ældre elever, der havde mundtlig undervisning og de yngste skriftlig. En god ting ved denne fremgangsmåde var, at når man hørte til de små og var tidligt færdig med at skrive på tavlen, kunne der læres meget ved at lytte til det, de store fik fortalt.

Lærer Petersen havde studeret i Kiel. I krigen blev han taget til fange og ført til England. Han var bestemt i sin optræden og krævede respekt. Hvis nogen sad og hviskede i timen og var urolige, lød der først en advarsel, og hvis den ikke hjalp, var der ikke langt til spanskrøret, der havde sin plads oppe på dørkarmen.

Især var der to drenge, som ikke kunne styre sig. De var slet ikke frække; de havde bare et sprudlende humør, så spilopperne ligefrem lyste dem ud af øjnene. Somme tider kunne det knibe for læreren at holde smilet tilbage, men orden skulle der være, så han holdt masken. En overgang var de hver eneste dag ude i forstuen og fik et par rap af spanskrøret, så støvet stod ud af de uldne bukser.

Om sommeren skulle vi møde om morgenen kl. 7. Heldigvis havde jeg kun et kvarters gang til skolen. De fleste havde meget længere, og de kom alle til fods, undtagen de to spilopmagere, der ejede en gammel cykel, som de kaldte stenknuseren. Læreren ville ikke have cykler stående ved skolen, men drengene fik lov til at stille dem hos Ida, en gammel kone, der boede i et langt, lavt hus tæt ved skolen. Huset var så lavt, at vi sagtens kunne nå op til taget. Foran de smårudede vinduer groede nogle mægtige buksbom.

Ida havde været alene i mange år. Hendes ene arm var tyk og blå og delvis 
lammet. Hun gik altid i noget mærkeligt tøj, der sjældent blev vasket. For at holde styr på det lange tjavsede hår gik hun med kasket, en sixpence, som hendes søn havde efterladt, da han drog ud at sejle. Til hendes glæde og stolthed nåede han at blive styrmand.

Idas arbejde var at gøre rent i skolestuen og ordne de to toiletter $\mathrm{i}$ udhuset. Toiletter, som vi nu kender dem, var det langtfra. Hun skulle tømme lokumsspandene på møddingen og sørge for, at der lå avispapir på WC-brættet til afbenyttelse. En kasseret telefonbog var glimrende til dette formål. Bladene havde en passende størrelse, og der var nok af dem til flere måneder. Ovenikøbet var der en strop af sejlgarn i det ene hjørne af bogen, så den kunne hænge på et søm. Byboerne var lidt finere. De havde »Træk og slip«.

Der var ikke megen plads i Idas hus; en lang smal gang, et lille køkken og en stue, hvor der stod en kakkelovn, en seng, et klædeskab, et bord og tre stole. Cementgulv over det hele og ingen tæpper. På bordet stod en petroleumslampe og den ældste symaskine, jeg nogensinde har set. Den var ikke ret stor, men sy kunne den. Lige een til at opbevare på museum. Alt var af massivt jern. Desværre er den sikkert blevet smidt væk eller solgt som gammelt jern efter Idas død.

I frikvarteret fik vi somme tider en snak med Ida, for hendes have stødte op til legepladsen. Hun kom ikke sammen med naboerne, var jo også på flere måder anderledes og holdt sig helst for sig selv. Os børn ville hun dog gerne sludre med.

Vi havde ingen skoleklokke, der ringede når frikvarteret var forbi. Læreren kom ud og klappede $\mathrm{i}$ hænderne, og så var det om at skynde sig ind på plads og stå ret indtil han sagde: »Sæt jer!«.

Mandag og torsdag var vi i skole hele dagen afbrudt af en pause, hvor alle gik hjem for at spise middagsmad. Lørdag var ikke fridag. Legepladsen skulle gøres fin til søndag, vi kom i gang med hakker og river ind imellem undervisningen.

Sommeren var herlig, vi boede jo så tæt ved vandet. Fra skolen var der heller ikke ret langt til stranden, og nogle gange tog læreren os med ud at bade. Drengene badede sammen med ham. Pigerne fik anvist et andet sted i nærheden. Jeg var meget bange for at gå i vandet efter at to af de største piger en dag tog fat om mine arme og ben og svingede mig frem og tilbage, så jeg af og til fik hovedet under vand. Det glemmer jeg aldrig, jeg kunne godt havde skreget af rædsel.

Hvorfor jeg skulle kanøfles vidste jeg godt. Jeg havde så let ved at følge undervisningen i timerne. Det hele gik som en leg, ligemeget om det var skriftligt eller mundtligt. En gang kaldte læreren mig hen til den store tavle for at regne en opgave, som de tre år ældre elever ikke havde kunnet klare. Det skulle 
han aldrig have gjort. Han tænkte sikkert ikke over, hvilke følger det ville få. Selvfølgelig blev de store både misundelige og vrede på mig. "Sådan en lille pjattet unge, der bare ville vise sig«. Det skulle hævnes, og det var meget nemt gjort, for var jeg foran dem i kundskaber, så var jeg dem underlegen i alt andet - nervøs og bange. Heldigvis blev det kun til denne ene hændelse.

\section{Skoleudflugter og ferier}

Sommerens store begivenhed var den årlige udflugt til hotel $»$ Den gyldne Løve« ved Varnæsvig. Det var kun for de fire yngste hold og deres forældre. Bare det ville blive solskin, for vi kørte med hestevogne, som bønderne stillede til rådighed den dag.

I Varnæsvig legede læreren med os ved stranden og i bøgeskoven, og vi fik rød sodavand eller hvid sportsvand. Der var ikke mange slags at vælge imellem. Vi kunne købe runde ispinde til 10 øre; med chokoladeovertræk kostede de 15 øre, og der var de dyre, firkantede til 25 øre. Efter at kuskene havde fået hestene spændt fra vognene, satte alle de voksne sig udenfor ved små borde og drak kaffe, mens snakken gik livligt. Ovenpå sådan en herlig dag var vi godt trætte og kunne ind imellem sidde og halvsove på hjemturen om aftenen.

De store børn kom på en længere udflugt, f.eks.til Kolding, Sønderborg eller Ribe. Første gang jeg kunne komme med, gik turen med tog til Vejle, Grejsdalen og Jelling. Vi kørte tidligt om morgenen med hestekøretøj for at nå toget i Aabenraa. Regnen styrtede ned, og da vi kom til banegården, var min frakke gennemblødt. Det værste var, at foret var smittet af, så der var kommet store brune pletter på min hvide kjole. Jeg var fortvivlet over at gå og se sådan ud hele dagen, men hvad andet var der at gøre? Op ad dagen klarede vejret op, og det gjorde mit humør også, og vi landsbybørn så og oplevede så meget spændende, at jeg helt glemte at tænke på min ødelagte kjole.

Kartoffelferien - efterårsferien - varede i to uger, og da blev der samlet kartofler op rundt omkring på gårdene. Både drenge og piger mødte op, for selv om det var strengt arbejde og gav en øm ryg, var det nu rart at tjene et par kroner, som var helt ens egne. Lønnen var lille, det blev ikke til nogen stor sum, men de fik da også føden i de dage. Maden var ikke lige god alle steder, og det blev kartoffelopsamlingen af den grund heller ikke.

Christine og jeg var aldrig med ved dette arbejde. Der var nok vi kunne gå i gang med derhjemme: pakke æg, rydde op på hylderne i butikken, gå byærinder o.s.v. og det var da meget sjovere, selvom vi ikke fik penge for det. Vi manglede aldrig noget.

Juleferien varede til lige efter Hellig 3 Konger. Påske- og pinseferien var lidt længere, end den er nu på grund af den korte sommerferie. Om vinteren skulle 
vi møde hver morgen kl. 8. Tit var der meget sne, og da vejen ikke var skovlet fri for driver på den tid af dagen, gav det våde fødder i træskoene.

Det blev bedre, da de første gummistøvler begyndte at komme i handelen. Desværre havde mange ikke råd til at købe dem, navnlig ikke familier med flere børn. Christine og jeg hørte til de heldige; vi fik hver et par sorte, blanke støvler. Sikken fryd det var at rende rundt i dem, selvom vi frøs om tæerne, og vi havde endda lange, tykke hjemmestrikkede uldstrømper på.

\section{Påkladning}

Dengang var påklædningen helt anderledes for både voksne og børn. Inderst havde vi en særk, som mor havde syet. Den var af lærred med hæklede takker i hals og ærmegab. Derover et hæklet eller strikket livstykke af uldgarn, nærmest som en slipover. Nederst $\mathrm{i}$ hver sidesøm sad en knap, hvor hosebåndet, en bred grå elastik med knaphuller, blev anbragt og derefter knappet på strømperne, for at de ikke skulle hænge alt for meget i ål. Så blev de rummelige rosa eller lyseblå bukser med elastik og lodden vrang trukket på. Trusser kendtes ikke. Derefter kom underkjolen af samme tykke materiale og til sidst den uldne kjole og forklædet.

Om vinteren en strikket trøje, som for alvor var kommet på mode omkring trediverne, da kom der strikkebøger og garn i forretningerne. Det var noget helt nyt, det måtte jeg også prøve, og da jeg var 12 år, strikkede jeg en bluse til Christine og mig selv. Forklædet gik vi med hele dagen, også i skolen, for at skåne kjolerne, der var besværlige i vask. Nu går vi jo alle i lange bukser, en varm og praktisk påklædning til både unge og gamle. Hvis nogen havde vovet det for 60 år siden, var der nok blevet snakket i krogene om sådanne letsindige pigebørn.

Jeg fik et par lange lysegrå bukser, da jeg var 16 år, og det vakte ikke så lidt opsigt. På en cykeltur satte det ene bukseben sig fast i kæden, og efter den oplevelse tog jeg altid en elastik om eller brugte bukseklemmer. Om sommeren gik vi i bomuldskjoler og ankelsokker, og hvis det var meget varmt med bare fødder i lærredssko eller sandaler.

\section{Mindehøjtidelighed 1931}

Den 21.august 1931 fik vi en ekstra fridag. Sammen med læreren gik vi alle til Felsted for at overvare højtideligheden ved den sten, der for 10 år siden var blevet afsløret til minde om de 89 faldne fra Felsted sogn under krigen 1914-18. Jeg havde ikke hørt om det i forvejen og anede ikke, hvad der skulle foregå. Desuden havde jeg nok andet at tænke på. Jeg måtte småløbe for at følge med de andre i flokken, og mine pæne sko, der kun blev brugt et par gange om året, havde gnavet hul på hælen. Endelig nåede vi målet. 
Der var tæt af mennesker fra hele sognet og alle så alvorlige og bedrøvede ud.

Jeg stod der, en lille 10-års pige med et følsomt sind, og holdt far og mor i hånden, og jeg så dem græde da hele forsamlingen stemte i med

»Slumrer sødt i Slesvigs jord,

dyrekøbt den blev ved eder«.

Far og mor græd ... da forstod jeg, hvor ond krigen havde været mod dem og alle de andre.

Mindestenen kunne jeg ikke se for de mange mennesker og heller ikke høre talen. Men nu begyndte alle at synge:

"Det lyder som et eventyr, et sagn fra gamle dage.

En røvet datter, dybt begrædt, er kommet frelst tilbage.

Det sker, hvad som et drømmesyn

har strålet for vor tanke.

Til sommer vajer Dannebrog

igen på Dybbøl Banke.«

Jeg var jo kun et barn og for første gang gik det rigtigt op for mig, hvad det betød, at Sønderjylland var kommet tilbage til Danmark, og hvilken lykke det er at være dansk.

Efter denne bevægende oplevelse gik turen atter hjemad. Mor tog mine sko af og puttede dem i tasken, og far tog mig op på cyklen foran sig. Der sad jeg trygt og godt mellem hans arme.

\section{Jule- og nytårstiden}

Var skoleudflugten sommerens store begivenhed - stå mål med vinterens højdepunkt, den glade, dejlige jul, kunne den dog ikke. Skolens julefest blev altid holdt den 22. december, og længe før havde læreren sammensat et program, som skulle opføres for vore forældre og andre, der havde lyst til at være med.

Der blev lavet en teaterscene på en forhøjning bag katederet. Her skiftedes vi til at stå og sige juledigte frem, som vi havde lært udenad. Andre spillede et »teaterstykke«, en lille skolekomedie. Og vi sang i kor nye julesange og de gamle kendte julesalmer. Læreren læste juleevangeliet og holdt en tale, der mest henvendte sig til vore forældre. Han var i kjole og hvidt, og Merethe, hans milde og venlige kone, som vi alle holdt af, var meget smuk i en kongeblå fløjlskjole. Det var virkelig festligt.

Juletræet, der stod tændt $\mathrm{i}$ et hjørne af skolestuen, var ikke ret stort. Der 
var ikke plads nok midt på gulvet til at vi kunne gå omkring det, men efter at juleposerne var blevet omdelt, blev der ryddet et par bænke til side, så vi kunne danse lidt rundt til musikken fra en harmonika. Kl. 12 var festen forbi. $\mathrm{Nu}$ havde vi juleferie i godt to uger, og om kun to dage var det juleaften ... herligt at tænke på.

I mit barndomshjem begyndte vi først rigtigt at snakke om julen, når det var omkring 1. december. Så måtte vi begynde at sætte vore sko i vinduet om aftenen, lige inden vi skulle i seng. Mon vi nu havde været artige, for ellers kom julemanden ikke og lagde en gave i dem om natten: en appelsin, en julekiks eller måske et lille stykke chokolade til 2 eller 5 øre.

Vi kendte hverken julekalender eller kalenderlys, og heller ikke i vinduerne var der lysestager, stjerner og alt muligt andet »juleri«. I nogle hjem plejede man at sætte en grankvist ved billederne af afdøde familiemedlemmer, det var alt. Intet under at juletræet med de mange stearinlys var som en åbenbaring for både børn og voksne i en tid, hvor der ikke fandtes gadelys, men hvor der var så mørkt, at man ikke kunne finde vej uden lommelygte.

En af de første dage i december blev der stillet julevarer frem i butikken. Der var pynt og lys til juletræet, der var marcipan- og chokoladefigurer og noget konfekt. Priserne var fra 2 øre til $1 \mathrm{kr}$. Nu kan der jo købes appelsiner hele året, men den gang var det kun til jul, og de var meget sure. Vi skar toppen af og pressede to stk. hugget sukker ned i hullet og gik så og sugede af saften til det sved i læberne. Men det var ligemeget: ingen jul uden duftende appelsiner.

Et år havde far købt en stor tønde amerikanske æbler, røde, store og flotte. Udseendet var der ikke noget $i$ vejen med, men de smagte ikke af noget som helst. De danske var meget bedre, og dem havde folk selv i haverne. Dadler og figner fik vi leveret $\mathrm{i}$ trækasser og vejede dem så af i poser med $1 / 2 \mathrm{~kg}$ i hver. Særlig pæne var de ikke; der kunne godt være nogle stumper sejlgarn imellem. Svesker og nødder blev også vejet af i portioner, så det var nemt, når julehandelen rigtig var $\mathrm{i}$ gang.

Husmødrene på landet bagte meget, både hvedekager, formkager, æbleskiver, småkager og pebernødder. Mor havde altid syv slags småkager, og de skulle være færdige inden 1. december. Vi havde nemlig den skik, at kunderne efter juleindkøbet blev budt ind i stuen til et glas vin og småkager. Nogle ægtepar kom først om aftenen. De fik kaffe, inden de gik hjem, og det kunne godt blive sent, inden far og mor fik fyraften. Arbejdsdagen var lang, og dog var det en dejlig tid.

Juleaftensdag lukkede butikken kl. 16, og derefter skulle der vaskes gulv og ryddes op overalt. Mor havde travlt i køkkenet med at lave den sønderjyske grønlangkål. De fleste får jo denne ret nytårsaften, men vi fik den altid til jul. Lillejuleaftensdag blev kålen plukket, skyllet flere gange og kogt med lidt salt 


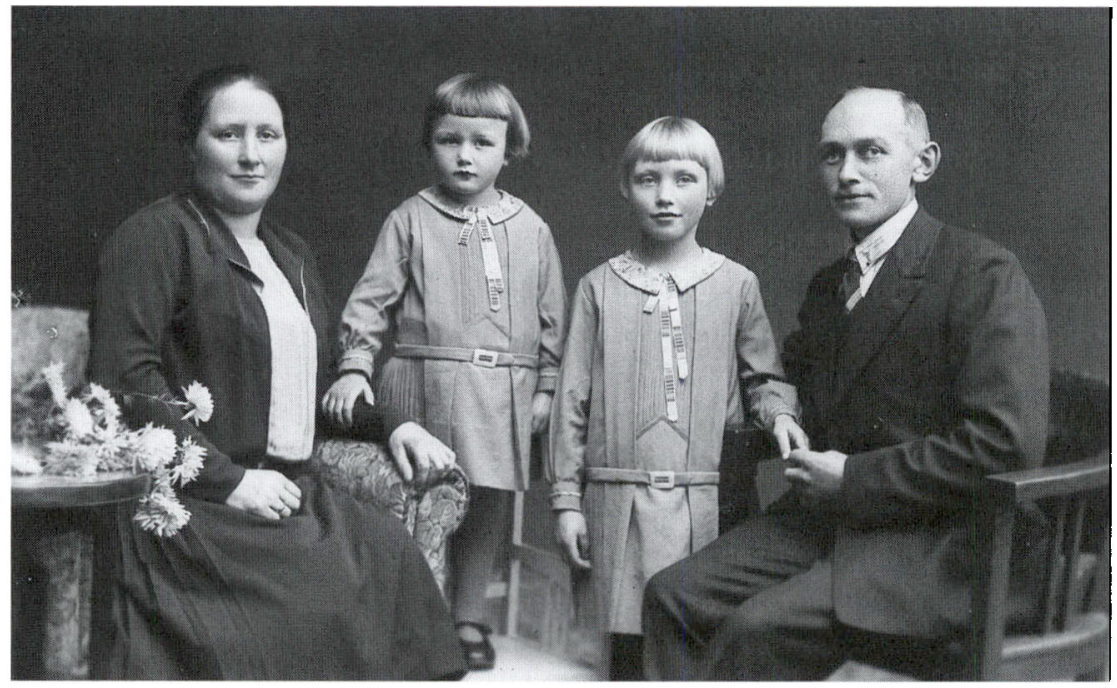

Familien Iversen hos fotografen $i$ 1928. Fra venstre min mor, Anna Iversen, min soster Christine og min far, Asmus Iversen. Privateje.

til den var godt mør, hvorefter den blev vredet op, d.v.s. at man tog store håndfulde ad gangen og pressede vandet godt af. Det var far god til med sine store, stærke hænder.

Samme dag blev det ferske og røgede flæsk kogt, og da fik vi til middag noget vi kaldte »mullebrød«. Tykke skiver rugbrød blev lagt i den varme suppe fra flæsket et par minutter, taget op på tallerkenen med en hulske og drysset med salt. Det smagte storartet.

Der skulle også koges en portion pillekartofler. Juleaften blev kålen og kartoflerne kørt gennem kødhakkemaskinen, ca. lige meget af hvert. Så blev det varmet $i$ en stor gryde sammen med mælk, suppe fra det kogte flæsk, en klat margarine eller smør, salt og peber og måske lidt fløde. Grønlangkålen blev serveret med det kolde flæsk, halve stk. rugbrød uden smør, og som tilbehør fik vi syltede græskar og kvæder eller asier og rødbeder. Vi drak julehvidtøl, og far og bedstefar fik en snaps. Desserten var kogte svesker og abrikoser med flødeskum.

Når vi var færdige med at spise, skulle der allerførst vaskes op, inden vi kom ind til juletræet, der stod pyntet inde i storstuen. Det var et stort øjeblik, når lyset $\mathrm{i}$ loftet blev slukket, og døren gik op til det strålende juletræ. Gaverne var ikke store og dyre, men hvor var det spandende at pakke ud, og hvor var vi glade. Det var jo kun til jul og fødselsdag vi fik lidt legetøj; ikke som nu, 
hvor børnene får gaver og legetøj hele året rundt. Det er synd for både børn og forældre.

Efter at vi havde sagt tak for gaverne og ryddet papir og bånd til side, satte vi os alle ned og fik salmebogen frem, for nu skulle de gamle julesalmer synges. Bedstefar var meget musikalsk, og det lød så kønt, når han sang med. Hans yndlingssalme var "Den yndigste rose er funden«. Hen på aftenen fik vi kaffe med mors dejlige julekager til, og somme tider spillede vi billedlotteri eller et terningspil. Når vi begyndte at blive søvnige, blev vi sendt i seng, og det varede ikke længe, så gik bedstefar hjem til sit. Far og mor blev heller ikke siddende længe; de var trætte oven på juletravlheden.

Nytårsaftensdag gik alle børn med en kurv på armen fra hus til hus og ønskede »godt nytår«, og når vi kom hjem i mørkningen, var der mange ting i kurven; appelsiner, æbler, kager og konfekt. Og der var julekiks med sukkerglasur, hvorpå der var klæbet et lille glansbillede. Figurer af dyr, som kunne købes hos bageren, var der også. Dejen var mest lavet af mel, vand og sukker, og kagerne var pyntet med røde streger. Alle disse nytårsgaver blev omhyggeligt sorteret og gemt $\mathrm{i}$ dåser. Mor smagte altid på småkagerne og ville vide, hvor de var fra. Måske var der en slags, hun skulle have opskriften på.

Nytårsaften var landsbyens unge ude på at lave sjov. En udhulet kålroe, hvori der var anbragt et tændt stearinlys, blev i ly af mørket sat ved folks indgangsdøre. Der var skåret huller til øjne, næse og mund, så det lignede et uhyggeligt dødningehoved. Nogle fandt på at holde en flaskerenser mod vinduesruden og gnide den med et søm, så det lavede et grueligt spektakel.

Der blev skudt med propbøsser og kinesere, så vor gamle hund hylede og peb og krøb ind under sofaen ... uskyldige løjer, som slet ikke kan sammenlignes med alle de meningsløse hærværk, der nu sker hver dag året rundt.

Jo! - det var sjovt og spændende ude i sneen og mørket en sådan nytårsaften. Alle kom ind til et glas kirsebærvin og de traditionelle småkager - godt at mor havde et stort lager. Også de nærmeste naboer samledes hos os den sidste aften i det gamle år. Når rådhusklokkerne slog tolv i radioen, rejste vi os alle op fra bordet og udbragte en skål med ønsket om et godt nytår og en tak for godt naboskab i det gamle.

Nytårsdag sov vi lidt længere om morgenen. Det var helt mærkeligt at komme ind i butikken, hvor der nu var så roligt og ikke noget at tage sig til.

En nytårsdag om formiddagen lød der et vældigt rabalder lige udenfor køkkendøren. Mor havde nogle tomme urtepotter stående ved hushjørnet, og da »æ Kaptejn« kom efter den pakke skrå, han havde glemt at købe, tog han en af urtepotterne og knaldede den i cementflisen, så skårene fløj til alle sider. »Godt Nytår«, råbte han. Mor blev nok lidt ærgerlig. Han kunne da i det mindste lade hendes urtepotter være i fred. 
Sådan var han, kaptajnen, en brumbasse, der med sammenknebne øjne under de buskede bryn gik forbi uden at hilse på dem han mødte undervejs. Han virkede tvær og utilnærmelig, snakkede højt med sig selv og snød næsen i fingrene. På mange måder en sær snegl, som vi trods alt godt kunne lide; en af dem der vinder ved nærmere bekendtskab.

Og så var han så dansk som nogen og gjorde sit til at få folk til at blive medlem af »Dansk Samfund" og »Det unge Grænseværn«. Efter mange års sejlads i Østen, især ved Kina, var han nu blevet landkrabbe. Der havde somme tider været år imellem, at han havde været hjemme hos sin kone og deres tre børn. Mange fine og sjældne ting havde han bragt med hjem fra fremmede lande. En gang forærede han mig en meget smuk sort silkekimono ivævet et fantastisk landskab med træer, blomster og fugle i strålende farver.

En bestemt dato hvert år var Kaptajn Danielsen i rigtigt krigshumør. Ikke tale om, at han ville have flaget hejst på sin fødselsdag den 20. april ... det var nemlig også Hitlers fødselsdag.

Kaptajnen boede kun nogle få huse fra bedstefar ved $æ$ vej, og de to var helt enige om, at tyskerne aldrig har villet os danskere noget godt. "Veee do hva«, sagde bedstefar, »hven dæ o kun va to tyskere tebagh å æ hele joe, så vil de gi sæ te o slås«. Naturligvis var det overdrevet, selvom det også rummer en hel del sandhed. Bedstefar var en rigtig gammel filur, som den gang han lo så smørret og sagde: »Dæ $\mathfrak{i t}$ mèe godt $i$ en tyske end $d \mathfrak{x} \mathfrak{x}$ honne (honning) $i$ en tuds«.

\section{Håb der brast}

Efter Hellig 3 Konger var juleferien forbi og alt igen i den gamle gænge. Læreren havde snakket med mine forældre om, at han syntes, jeg skulle begynde på Statsskolen i Aabenraa. Han mente jeg var begavet nok til at kunne tage studentereksamen og måske læse videre, og det var også fars og mors ønske.

Begavet ? ... et ord, der efterhånden er blevet betegnende for en god forstand, skønt det i al sin enkelhed betyder, at et menneske ved fødslen har fået tildelt mange evner, mange gaver, såsom: et kærligt sind, en velskabt krop, sundhed, gode kræfter og praktisk håndelag, at kunne spille, synge, male, være tilfreds og glædes over de små ting og leve $\mathrm{i}$ harmoni med sig selv og sine omgivelser. Alt sammen noget, der til syvende og sidst er lige så meget, ja, måske endda mere værd end intelligens.

Jeg kom ikke til at gå på statsskole. Skæbnen ville at det kom til at gå helt, helt anderledes. »Mennesket spår, men Gud rå’r $\ll$.

I en alder af 10-11 år begyndte jeg at skrante, havde ingen appetit, blev tynd og bleg og voksede slet ikke. Mor sørgede for at jeg fik næringsrig mad, og lægen gav mig medicin mod blodmangel. Men intet hjalp - jeg fik det stadig 
værre. En frygtelig angst kom snigende; ikke sådan at jeg var bange for mennesker eller ting der omgav mig. Det var en indre, grusom, uforklarlig angst, som truede med at tage magten. Lægerne stod magtesløse, kendte kun så lidt til depression og andre psykiske lidelser dengang, og da slet ikke iblandt børn. Hvis far og mor en aften skulle i byen, var jeg helt ulykkelig. Falde i søvn om aftenen kunne jeg heller ikke, og jeg turde slet ikke gå over vejen, ikke vove mig hjemmefra.

Følgen var, at skolegangen blev forsømt. I lange perioder måtte jeg blive hjemme og ligge i sengen. Drømmen om en boglig uddannelse brast som en boble. Det hele var så ligegyldigt, betød ingenting.

Skridt for skridt kæmpede jeg mig fremad, og var i 16-17 års alderen nået så langt, at jeg, bortset fra nogle dage en gang imellem, stort set havde det som alle andre. Depressionen, dette onde, uforklarlige, var næsten faldet til ro, men lå stadig i underbevidstheden og lurede ulmende som en vulkan, parat til at komme i udbrud, hvad det da også gjorde nogle gange senere i livet.

\section{En blandet landhandel}

I forretningen gik det godt fremad for far og mor, der begge var flittige og sparsommelige. Kundekredsen var vokset, og økonomien efterhånden blevet så god, at de i 1929 havde planer om at udvide butikken. Det var bestemt heller ingen luksus. Om aftenen sad far og tegnede og regnede, og da han var nået til et resultat, som de begge mente var det bedste, blev håndværkerne bestilt. Murermester Thomas Thomsen og tømrer Peter Autzen boede begge i Felstedskov. Der blev ikke bygget meget i den tid, så de var glade for at komme $i$ arbejde og kunne begynde med det samme.

Arbejdet med tilbygningen skred godt fremad. Murermesteren havde en såkaldt plejsmand med. Han hed Johannes Gjerlevsen, en pligttro arbejder, der hele tiden sørgede for, at der var mursten nok inden for rækkevidde. De blev kørt på en trillebør, og det kunne sagtens gå til at begynde med, men når muren blev højere, måtte han bære dem op ad en stige og sætte dem på stilladset. Der var hverken kran, hejseværk eller blandemaskine. Alt foregik ved håndkraft. Ved hjælp af en skovl blandede plejsmanden mørtel i trillebøren, hældte det $i$ en balje og bar det samme vej som murstenene.

Imens havde tømreren travlt med at få bjælker, spær og lægter parat, og så en skønne dag holdt vi rejsegilde. Naboerne kom med kranse med kulørte bånd og vimpler, og der blev holdt tale, skålet og råbt hurra for den nye forretning. Nogen tid gik der jo endnu, inden det hele var færdigt og varerne kommet på plads. Nemt og ligetil var det ikke med de mange vidt forskellige ting.

Det er helt utroligt, hvad der kunne være i sådan en blandet landhandel. Skuffer med kolonialvarer og krydderier, sygrejer og strømpegarn, tobaksva- 


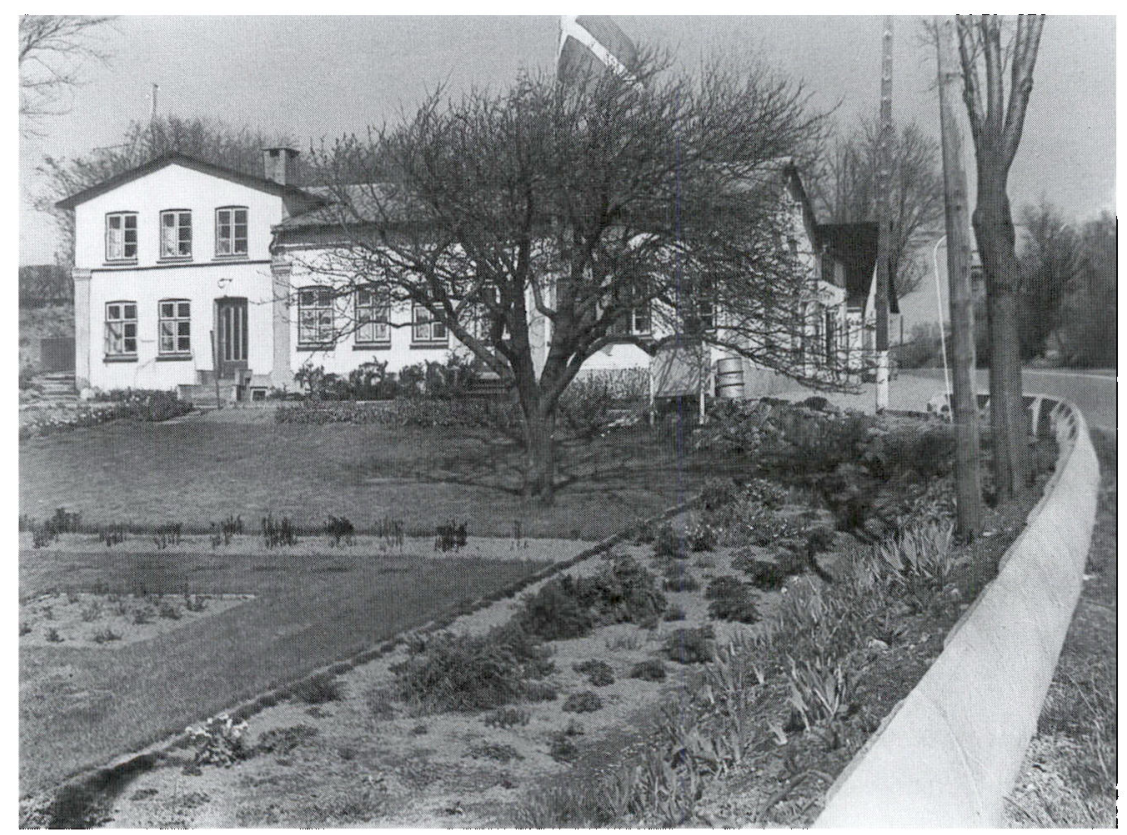

Hesselholt i 1950 'erne. Forretningen anes ud til vejen. Privateje.

rer, vin og chokolade, på en hylde oven over kaffemøllen tre store røde dåser med kaffebønner til 1,60 kr., $2 \mathrm{kr}$. og 2,40 kr. for $1 / 2 \mathrm{~kg}$ og en dåse med kakao til 60 øre for $1 / 4 \mathrm{~kg}$. I et hjørne på gulvet en træbeholder til $25 \mathrm{~kg}$ salt, en stentøjskrukke med sennep, hylder med vaskepulver, en stor, høj zinkbalje med brun sæbe, en pumpe til petroleum og en til sprit, hylder med glas, skåle, kopper, vaser og lign., vaskebaljer og vaskebræt, malkespande og malkestole, haveredskaber, reb, kotøjr, tøjrepæle, søm og skruer, hønsetråd og pigtråd, træsko, lærredsko, gummistøvler, kulspande og kulskovle, dørmåtter, piber, punge, skoletavler, grifler, blyanter, penne og blak, papirvarer, konserves, klipfisk, »Hatsogge« (topsukker), kasser med margarine, smør og fedt, en krukke med gær, gryder, pander, fade, syltetøjsglas, bestik og meget, meget mere.

Under butiksbordet - det var ingen disk - stod dåser med $2 \frac{1}{2}$ og $5 \mathrm{~kg}$ bolsjer, to sirupskander og en dåse med kandis. Det var små og store uensartede stykker, der lignede rav og var trukket på en stump sejlgarn. Der lå også en gammel tapetbog. Brun sæbe var jo, som så meget andet, i løs vægt. Den blev vejet af på pergamentpapir og derefter pakket godt ind i et stykke tapet. Omme bag døren hang bundter af papirsposer i forskellige størrelser til mel, sukker, gryn og hvad der ellers skulle vejes, og i en krog under loftet hang et stort nøgle sejlgarn, som det var nemt at tage af, når noget skulle pakkes ind. Saksen var 
bundet fast til en øloplukker, der var anbragt lige under bordpladen - meget praktisk, så var den altid lige ved hånden. Tape kendtes ikke. Indpakningspapiret var enten blegrødt, grågrønt eller brunt, ikke noget med mønstre og farver.

Kasseapparat er nok en fin betegnelse til den pengekasse, der skjulte sig under bordpladen. Det var en skuffe i to etager med en række fjedre under bunden. Hvis man ikke trak i netop de tre rigtige på een gang, kunne den ikke åbnes - jeg husker dem endnu. I den nederste etage lå pengesedlerne, 5 - 10 $50-100 \mathrm{kr}$., og en sjælden gang en »Plovmand«, $500 \mathrm{kr}$.-sedlen med det kønne motiv af en pløjende bonde med hesteforspand. I den øverste etage var der runde fordybninger til mønterne, $1-2-5-10-25$ og 50 øre, samt een- og tokroner.

Midt på bordet stod vægten med messingskåle og de små messinglodder, som blev pudset hver lørdag. De store jernlodder blev bare tørret af. En lørdag, far stod og pudsede, kom politimesteren fra Aabenraa ind af døren. »Det må jeg sige« udbrød han, »de er vel nok skinnende blanke«, tog et lod i hånden og kiggede på det. »Ja, såmænd«, bemærkede far tørt, »og de er alle justerede $\ll$. - Tavshed. Ingen kommentarer.

Samme politimester var nu ikke så tosset endda. Han vidste godt, at det var næsten umuligt for os at overholde lukkeloven, for når butiksdøren var låst, benyttede folk bagdøren. Det var strafbart at handle efter lukketid og kunne nemt ende med en bøde, så når politimesteren om sommeren kørte forbi med rutebilen på vej til sit sommerhus, var han altid så betænksom at sidde med ryggen til vinduet. - "Hvad man ikke ser, har man ikke ondt af «.

Foruden varerne $\mathrm{i}$ butikken var der oppe på loftet et lager af sxkke med mel, gryn og sukker. Det huggede sukker lå i tætpakkede lag i en trækasse. Helt let var det ikke, når de store, tømte skuffer fra butikken skulle fyldes oppe på loftet og bæres ned ad trappen.

Næsten alting blev før i tiden vejet af, mens kunderne ventede. De medbragte selv glas eller stentøjskrukker til sirup, flasker til eddike og sprit og kander til petroleum. Eddike- og sirupstønderne lå på en stærk, lav bænk. Sådan en fuld sirupstønde vejede $100 \mathrm{~kg}$, og når den skulle læsses af lastbilen, blev der lagt et bildæk på jorden til at tage imod det værste stød.

Engang gled tønden ud af hænderne på chaufføren og hans medhjælper med det resultat, at den revnede, og sirupen som en lavastrøm banede sig vej ned forbi butiksdøren, ned ad en skrænt og endte helt nede i den anden ende af haven. Der var ikke andet at gøre end at få den klæbrige masse skovlet væk og kørt nyt grus på. Nede i haven kunne sporene ikke fjernes helt, og her blev der hele sommeren et sandt Eldorado for bier og andre insekter.

Når petroleumstanken var tom, blev der sendt bud efter petroleumsvognen, der blev trukket af to stærke jydske heste. De måtte lægge alle kræfter i for at 
slæbe den tunge vogn, og når de var nået halvvejs op ad Hesselholt, fik de lov til at tage et lille pusterum. Den ene af hestene havde fåt den vane hver eneste gang at aflevere en stor stak "pærer« lige uden for døren. Straks var mor der med spand og skovl, for der fandtes ikke noget bedre til hendes mange flotte stauder og jordbærplanterne end hestegødning.

Et lille, meget lille, brødudsalg manglede heller ikke. Det var såmænd bare et par hylder i spisekammeret, hvor rugbrød, franskbrød og sigtebrød lå på rad og række. Tvebakkerne, 8 stk. for 10 øre, havde deres plads i en skuffe i butikken. Hver fredag kom bager Wandahl fra Varnæs kørende med Lotte foran den gule, spinkelt byggede brødvogn. I stedet for en bagsmæk var der to luger, der vendte til hver sin side. Hvis der blev udsolgt inden ugen var omme, fik vi ny forsyning med rutebilen.

Den travleste dag i hele ugen var onsdag, hvor bønderne kom med store kurve æg og fik varer med hjem. \#ggene blev vejet og pakket i trækasser, der kunne rumme 500 eller 1000 stk., hvorefter de blev afhentet af Odense Ægforretning. Der var ca. $6.000-8.000$ æg om ugen, og Christine og jeg var ikke ret gamle, før vi blev sat til at pakke. Om vinteren var det en kold bestilling. Nogle kunder kom langvejs fra, og æggene var iskolde, nogle endda revnede af frosten, inden de nåede frem. Den laveste pris, jeg kan huske, var 56 øre pr. kg. og da den så nåede op på 1 kr., kom der gang i salget af kyllingefoder samt trådvæv til hønsegårde.

\section{Kriseår}

Det var i tredivernes krisetider, hvor landbrugsvarerne var så billige, at en slagteko kostede $75 \mathrm{kr}$. For mange var det håbløst at skaffe penge til kreditforeningsrenterne, og følgerne blev de mange "afhandlinger" og tvangsauktioner. Det kom til at gå ud over mine forældre på den måde, at de ikke fik så meget som een krone tilbage af de penge, de rundt omkring havde tilgode for købmandsvarer. Når bønderne "handlede af«, blev der ingen penge tilovers til købmanden. Gælden blev slettet og kontobogen brændt. Heldigvis kunne mine forældre klare det økonomiske tab, men bittert var det nu alligevel.

Tiden var vanskelig for alle, ikke mindst arbejderklassen. Der var heller ingen folkepension eller aldersrente, som det blev kaldt til at begynde med. Ikke så mærkeligt, at der blev spinket og sparet $\mathrm{i}$ alle ender og kanter for at have lidt tilovers til »sin gammel daw«, så man kunne undgå den ydmygelse at ende på fattiggården.

For bønderne så det lysere ud, når de blev gamle og en søn, som regel den ældste, kunne overtage gården. Så flyttede de gamle ind i aftægtsboligen, hvor de havde gratis ophold og desuden fik brændsel, mælk, smør og æg og til jul en halv gris til sulekarret. 
En dag, det har nok været i 1929, da far havde et ærinde på "æ Armhus« (fattiggården) var jeg med derinde, og jeg glemmer det aldrig. Det var et stort rum med teglstensgulv, koldt og uhyggeligt. Langs væggene, på de hårde træbænke, sad de gamle mænd og koner krumbøjede, frysende og forkølede. Føden bestod mest af kartofler og grød. Der blev ikke snakket meget, de sad der bare, apatiske, uden at have noget at tage sig til andet end at vente på døden.

Der bliver så tit fortalt om de gode gamle dage. Men var de nu altid så gode? Nok var der mere hygge og sammenhold den gang, og man gav sig bedre tid, var ikke så forjagede. Men ellers - nej! Når man tænker på alle de goder, vi har i dag, både samfundsmæssigt og $\mathrm{i}$ det daglige, så er der nok ingen, der ville bytte med »de gode, gamle dage«.

\section{Varnoss-vejen udbygges}

Der havde i nogen tid været planer om at vejen fra hovedvej 10 gennem Hostrupskov og Felstedskov til Varnæs skulle reguleres, og i 1929 kom arbejdet i gang. Bl.a. skulle der graves mange kubikmeter jord af bakken ved Hesselholt og køres ned i den dybe lavning.

Det foregik med tipvogne forspændt en traktor, og det så helt livsfarligt ud, når den lange række af vogne fyldt med jord og ler slingrende ud og ind på det smalle jernbanespor kørte ned mod dybet. Der var tryk på, og en dag gik det da også galt. Bremserne svigtede, vogntoget løb af skinnerne og styrtede ned i afgrunden. Heldigvis nåede føreren at springe af i tide; men nu fulgte der et kolossalt arbejde med at få alle vogne slæbt op igen og sat på skinner. Arbejderne havde det svært nok i forvejen.

Hvis en ny mand gerne ville antages, stod entreprenøren, slavepiskeren, som han blev kaldt, hele dagen og holdt øje med ham, og hvis tipvognen ikke var fuldt læsset samtidig med de andres, kunne han godt gå hjem og ikke vise sig igen den næste dag. Et arbejdsskur med varme var der ikke. Ikke en gang et lokum fandtes der. Når mændene trængte til at komme af med »affaldet«, gik de ind $\mathrm{i}$ kornmarken og satte sig ved diget under et tjørnehegn, så der efterhånden stod en hel »vagtparade«.

Var entreprenøren en hård hund ved sit folk, så var formanden, »ham Pæersen « mere human; han gjorde ikke en kat fortræd og lignede i mangt og meget $æ$ ækaptejn. Ham Pæersen gik ud og ind i vort køkken som det passede ham, og da han en morgen så en kop stå i vindueskarmen, satte han den til munden og drak hele indholdet på een gang. Pludselig begyndte han at hoste og harke og forsvandt ud af døren uden at mæle et ord. Det var fars barbervand med skægstubbe og det hele han havde drukket!

Mine forældre var lidt betænkelige ved udsigten til at kunderne måske ville svigte i den lange tid, der var vejarbejde, men det gjorde de heldigvis slet ikke. 


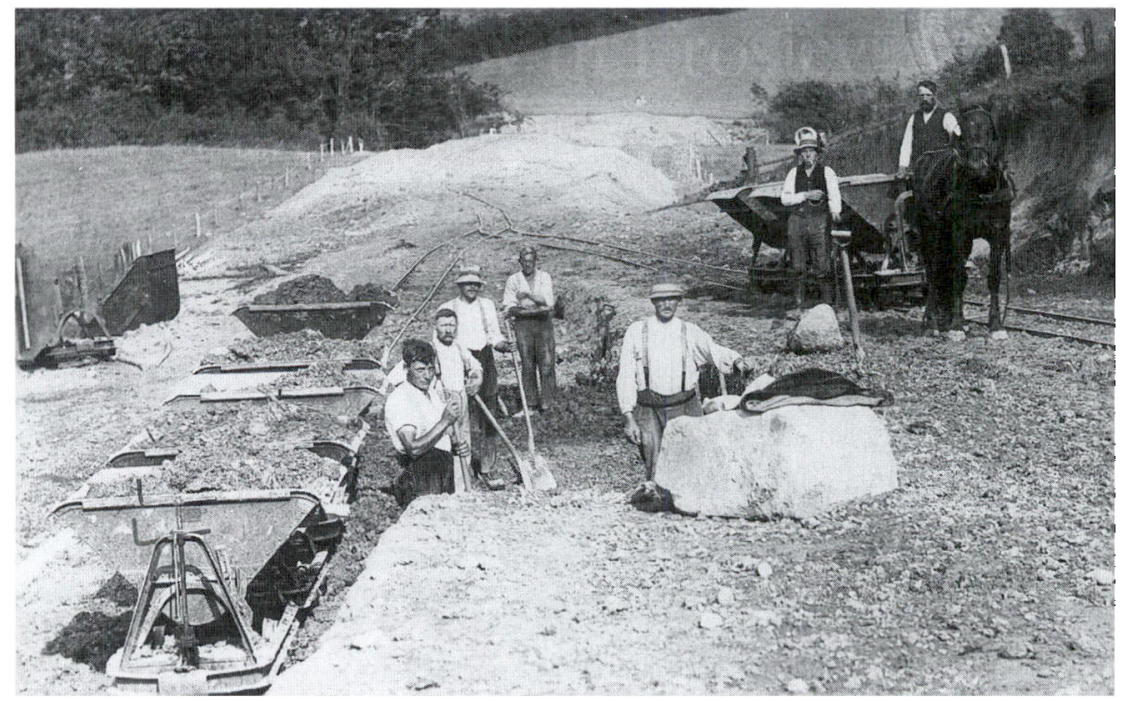

Det var hårdt arbejde at anlagge vej i $1920^{\prime}$ erne. Foto fra anlag af Varnas-vejen. Foto i Ensted sogns lokalhistoriske arkiv.

De tog det hele med godt humør, når de skrævede over skinnerne og vadede gennem pløret hen til døren.

Ved samme tid som vejarbejdet stod på, udbrød der en mund- og klovsygeepidemi, og vor ko fik også den smitsomme sygdom. I hast fik far aftalt med en bonde, at den kunne komme ind i stalden til hans besætning, der også var angrebet, og så blev den syge ko trukket bag om huset og hen over markerne til gården. På grund af smittefaren ville butikken ellers være blevet lukket, hvilket jo havde været en katastrofe, for hvor skulle indtægterne så komme fra?

Oven for Hesselholt står et transformatortårn, som far havde nøglen til. Hvis der var noget $\mathrm{i}$ uorden på ledningerne, blev der telefoneret, om han ville gå op og slå strømmen fra, og straks melde tilbage, når det var gjort, så linjearbejderne trygt kunne gå igang med at udbrede skaden. Det skete næsten altid $i$ et uvejr, også denne dag $\mathrm{i}$ isvinteren 1928-29.

Telefonen ringede: „Gå med det samme op og sluk for strømmen!« Far tog straks sit lange gule, blåstribede halstørklæde oven på sixpencen og bandt det $i$ en mægtig knude under hagen - et kosteligt syn. Fødderne blev i en fart stukket i gummistøvlerne, mor hjalp ham frakken på og så vadede han i snefoget op til transformatortårnet. Kommet indenfor greb han fat $i$ håndtaget for at dreje, som han havde fået besked på, men stivnede i det samme og stirrede chokeret ... strømmen var afbrudt! Havde han fulgt ordren, ville det have fået 


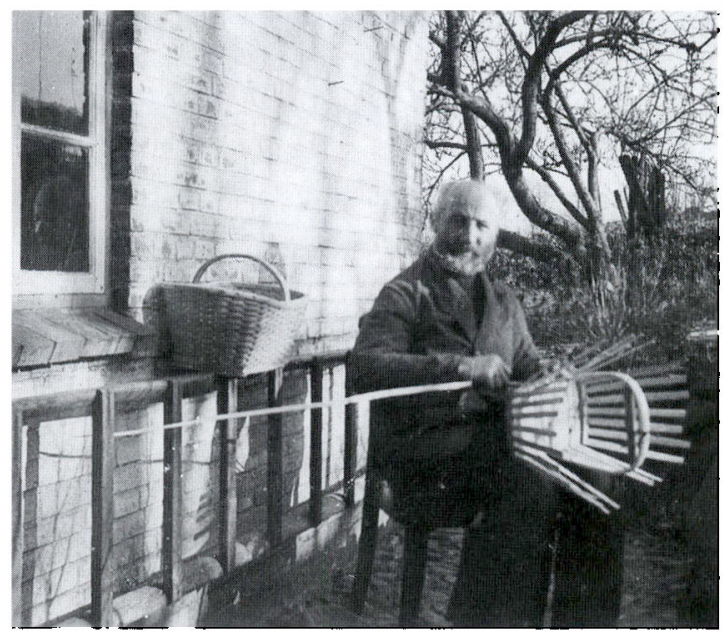

Bedstefar Rasmus Hindrichsen $i$ Felstedskov $i$ gang med at flette kurve. Foto ca. 1940 i privateje.

frygtelige følger. Endnu rystet, men lykkelig og taknemmelig, kom han hjem og fortalte, at han, som ved et mirakel, var blevet skånet for at være skyld i andre menneskers død og ulykke.

\section{Bedstefar kurvemager}

De næste par år gik uden nævneværdige begivenheder. Jo! Een var der alligevel, som fik stor betydning, især for bedstefar ved æ vej. Vi havde omsider fået ham overtalt til at anskaffe en trehjulet cykel. En almindelig tohjulet havde han aldrig haft og ville hverken eje eller have sådan et monstrum, der kun var ude på at smide ham af. Sine egne ben, dem kunne man styre, og de var til at stole på.

I mange år havde han travet hele sognet igennem på kryds og tværs med tre-fire kurve bundet sammen med et reb og hængt over skuldrene. Bedstefar flettede nemlig kurve og leverede dem efterhånden, som de blev bestilt. Der var tørvekurve og tøjkurve samt små og store købmandskurve; de store kunne rumme 200 æg.

Man kan godt sige, at han startede fra bunden, da det var den, der først blev savet til rette af en træstamme, han havde liggende. Derefter begav han sig til Syvmandsskoven, hvor han havde faet lov til gratis at hente alle de pilegrene, han havde brug for.

Det var en hel proces, disse grene måtte igennem. Lægges i blød i lange trug, afbarkes og skæres igennem på langs, så de blev flade på den ene side. I kurvebunden blev der lavet huller til de opretstående lister, hanken blev bøjet og bundet sammen med en snor for at holde faconen. Det specielle, mærkvær- 
dige værktøj til fremstilling af kurven havde bedstefar selv »opfundet« og givet det højst besynderlige navne. Til allersidst, når han var tilfreds med resultatet af arbejdet, blev kurvene hængt til tørre i æbletræet nogle dage.

$\mathrm{Nu}$, da han havde fået den trehjulede, var det en smal sag at hænge dem på en krog bag på køretøjet og cykle ud til kunderne. Det var en rigtig festdag, for når Rasmus dukkede op rundt omkring på gårdene, skulle han da rigtignok værsgo' komme med indenfor til en kop kaffe. Snakken gik, og det var tit hen på aftenen, inden han nåede hjem fra udflugten.

\section{Konfirmation og forste "plads"}

I maj 1932 fik vi en søster, som blev døbt Astrid. Vinteren 1933-34 begyndte jeg at "gå til præst«, konfirmationsforberedelse, to gange om ugen hos pastor Mikkelsen i Felsted Præstegård. Mange gange var det et mareridt at komme af sted hjemmefra. Vejen var lang, altid op ad bakke, for det meste sne- og isglat. Jeg var syg af angst for at cykle alene og bange for at besvime undervejs. Far kendte min frygt og vidste, hvor jeg led. Han hverken skændte eller formanede, tog blot lige så stille sin cykel og fulgte mig så langt på vej, at vi kunne se præstegården.

Pastor Mikkelsen læste op af Det nye Testamente og forklarede os, at konfirmationen er en bekræftelse af dåben. Vi havde mange hjemmeopgaver for. Skriftsteder og lange salmer skulle læres udenad.

Konfirmationsdagen var Palmesøndag den 14. april 1934. Om morgenen vågnede jeg med feber og ondt $\mathrm{i}$ halsen og måtte hen på eftermiddagen krybe i seng. Gudskelov var det alt sammen gået godt $i$ kirken, og det var det skønneste forårsvejr. Solskin og høj, klar himmel.

Skærtorsdag var alle vi konfirmander for første gang til alters. Dengang var der ikke et lille bæger til hver. Vi drak alle af det samme store bæger, en kalk, som præsten gik med fra mund til mund hele raden rundt. Kanten blev nok tørret lidt med en serviet. Utilpas ved det var jeg nu alligevel, for lige inden det blev min tur var der en mand med et langt, stift, rødt »hvalrosskæg«.

I den tid vi gik til konfirmationsforberedelse, ville præsten gerne se os $\mathrm{i}$ kirken, helst hver søndag. Mine forældre var ikke flittige kirkegængere. Hvorfor ved jeg egentlig ikke. Måske var det den lange, besværlige vej på cykel og vel også den indstilling, at der var så meget at gøre, så mange ting der skulle ordnes, når far var hjemme om søndagen. Mor tog sig dog tid til at høre gudstjenesten i radioen så godt som hver søndag, og når pastor Mikkelsen om vinteren holdt bibellæsning i skolestuen hver anden fredag aften, var vi alle med.

$\mathrm{Nu}$ var jeg jo konfirmeret og fyldt fjorten år og blev derfor regnet for at være voksen. At være konfirmeret betød det samme som at sige farvel til skolen 
og komme ud at tjene. For mig var det et held, at den unge tjenestepige, der nu havde været på Hesselholt i tre år, gerne ville prøve noget andet, og da hun flyttede til 1. maj, kunne jeg blive hjemme og hjælpe til i stedet for. I begyndelsen kneb det nogle gange at blive frerdig til tiden, men så trådte mor hjælpende til. Hun havde et par rappe hænder og fik tingene sat på plads i en fart, og skønt der var meget at se til i dagens løb, beklagede hun sig aldrig. Det var også mor, der stillede sig imellem, når far blev vred og hidsig, hvis Christine og jeg havde forset os - lystre, det skulle vi. Inden han nåede at løfte hånden til slag, så hun bare på ham og sagde: »Men Asmus da!« og vi slap for en lussing.

\section{Fro af ugras}

I mellemtiden skete der store ting i Tyskland. Der havde længe været noget i gære, og nu stormede nazismen med Adolf Hitler i spidsen frem og overtog magten i 1933. Det var fantastisk, at en enkelt mand kunne få en hel nation til at følge sig, ja næsten tilbede ham som en afgud.

Arbejdsløsheden og fattigdommen var stor i Tyskland, og de havde ikke glemt nederlaget, den tabte krig 1914-18. Når Hitler viste sig på talerstolen, indledte med »Volksgenossen $«$ og lovede dem alverdens goder, bl.a. en Folkevogn til hver familie, kendte jubelen ingen grænser. Til at begynde med talte han nogenlunde normalt $\mathrm{og}$ roligt, men hidsede sig efterhånden op og råbte og skreg til han blev hæs. Og folkeskaren skreg med: »Heil Hitler«, - "Heil Hitler«. »Der Führer«, denne ene mand havde en uhyggelig, hypnotisk magt over alle, og de fulgte ham blindt.

Herhjemme begyndte der også at komme nazister; selv i den lille, fredelige landsby Felstedskov stak de hovederne frem. Der boede kun få såkaldte hjemmetyskere i vor by, og der var aldrig før blevet diskuteret politik. Man kom sammen som gode naboer og respekterede hinandens mening. En enkelt familie deltog altid, når der var møde i den tyske forening i Felsted. Her var også en tysk skole, som forsøgte at »købe« elever fra omegnen ved at tilbyde børnene en ny cykel. Det mislykkedes heldigvis, forældrene sagde bestemt nej! Ikke en eneste fra Felstedskov kom til at gå i tysk skole. Den omtalte tysksindede familie have ingen børn.

Så fik piben pludselig en anden lyd. Da Hitler viste sig på scenen, var der ingen ende på deres lovtaler om »Der Führer«. Inden ret længe ville vi også tilhøre »das große Vaterland « ... »Deutschland über alles!«

Sådanne udtalelser vakte naturligvis harme. Hvorfor skulle vi altid trampes på? I alle årene fra 1864 til 1920 havde sønderjyderne måttet holde mund, rette sig efter prøjsernes parole og var ovenikøbet blevet skældt ud for $» d u m m e$ Dänen«. Nu så de igen en lejlighed til at ydmyge os. Det var dog ikke alle 
hjemmetyskere, som tænkte sådan. Især blandt de ældre, der havde oplevet 1 . Verdenskrig, var der en vis skepsis overfor Hitlers politik, og de holdt sig neutrale.

Værre og langt mere bittert var det, at der var overløbere blandt de ellers dansksindede beboere. Før i tiden havde der mange gange været hyggeligt og rart i butikken, når kunderne mødtes og fik en munter snak. Nu ændrede det sig. Folk skulede til hinanden, vidste knap hvad de turde sige ... Trist, ja sørgeligt var det, at vi ikke mere kunne stole på dem, vi havde været gode venner med i så mange år. Selvfølgelig snakkede vi sammen, men hjerteligheden og tilliden var borte og mistanken trådt $i$ stedet.

I Bovrup, kun få km fra Felstedskov, var lægen Frits Clausen blevet meget begejstret for nazismen. Unge mænd, hvoraf nogle kun var store drenge, lod sig rive med uden egentlig at gøre sig nogle tanker om, hvad det hele drejede sig om. Eventyrlysten lokkede, og de kaldte sig for danske nazister. Desværre var der også voksne mænd, som burde have været klogere, med i denne flok, der hver søndag kom marcherende fra Bovrup ned forbi »Hesselholt« med hagekorsflaget i spidsen.

Da en rask dreng fra den kernedanske familie Walsted på Felsbæk Mølle tilfældigvis mødte en nabo, der hver dag spankulerede rundt i fuld naziuniform: lange støvler, spidsbukser, jakke med skrårem, høj kasket og armbind med hagekors, stillede han sig lige over for ham og sagde: "Sej mæ engang, æ do general eller admiral, for naue mæ ral må det da væe med ålt det skidt, do hæ hången å din jak.»

Flere og flere, også dem som vi aldrig havde tiltroet det, sluttede op om Frits Clausen og meldte sig ind i partiet. Der var ingen ende på deres lovprisning af "der Führer«, og vi fik spydigheder og hånende bemærkninger, når disse tilhængere kom i butikken. De lagde huskesedlen på bordet og skyndte sig op på »Højskolen«, der var blevet en slags samlingssted, og her gik bølgerne højt. Efter 9.april 1940 var det deres faste overbevisning, at krigen snart sluttede med en stor sejr til Hitler, og Tyskland ville genopstå som det tredje Rige, verdensmagten der regerede og bestemte overalt.

Noget af det mest oprørende og ubegribelige var, at vor nærmeste nabo sammen med en anden nabokone, der var lige så fanatisk, klippede deres Dannebrog, korsbanneret i stykker og syede det til armbind, ganske vist også med et kors. Men dette kors var ikke uden hager. Overalt mødte man det forhadte tegn malet eller ridset på vægge, døre, plankeværk o.lign.

Far kunne ikke tåle at se denne modbydelige propaganda, og da der en morgen i besættelsesårene hang en stor plakat på vor garageport, hvorpå der stod at alle, der ikke sympatiserede med Det tredje Rige, ville blive udslettet, blev det ham for meget. Han rev plakaten ned, gik op på »Højskolen« med 
den og sagde, at dette her ville han have sig meget frabedt - nu gik det for vidt.

Volksgenosserne mente, at han stod i forbindelse med Frihedskæmperne, og denne mistanke var heller ikke uden grund. Den store, nedgravede tank ved butikken var fyldt med benzin, og her havde modstandsfolkene fri adgang til den værdifulde væske. Heldigvis var naboen og hans søn rejst til Klagenfurt for at melde sig til tjeneste ved naziregimet - ellers var det nok ikke gået upåagtet hen.

I Hostrupskov, en lille landsby, som støder op til Felstedskov, ligger en gård godt gemt bag træerne i udkanten af skoven og usynlig fra vejen, der kun bliver benyttet af ganske få. Det var det ideelle sted for frihedskæmperne at søge hen, når de følte sig truet, og de gik aldrig forgæves til bonden Jørgen Meier. Han skjulte mange i besættelsestiden. Det var farligt spil, og hans indsats endte da også med, at der en nat blev kastet en brandbombe mod stalden, der snart stod i luer, og dyrene indebrændte. Gerningsmændene blev ikke eftersøgt - det klogeste var at sagen blev så lidt bekendt som muligt, og der kom heldigvis ikke flere dramatiske episoder.

\section{Isvinter og forelsket}

Trods den store omvæltning i Tyskland og gærende uro andre steder, var der ikke de store forandringer i hverdagen herhjemme. Og dog: jeg var blevet stormende forelsket. Vor nabo havde fået en ny tjenestekarl, og første gang jeg så ham, slog lynet ned. Han så nu også ualmindelig godt ud, og det var ikke kun i mine øjne. Andre piger sværmede også for ham.

Mor var selvfølgelig ikke længe om at opdage min hemmelighed og sagde en dag: »Ja, Marie, nu må du se at blive mere glad og komme ud blandt de andre unge, for han kan sagtens få en anden.« Det gav mig et skub fremad, og jeg blev meget lykkelig, da jeg snart blev klar over, at mine følelser blev gengældt. Endskønt vi kun var et par store børn på 16 og 17 år, var det ikke en flygtig ungdomsforelskelse, men en dyb og trofast kærlighed, der varede hele livet.

Hver dag i middagspausen gjorde Frits sig et arinde i butikken, og når far og mor en aften var i byen, kom han på besøg. Det vidste de selvfølgelig godt, men Christine var jo hjemme, så vi havde anstandsdame, og hvor havde vi det vidunderligt i denne polarvinter 1936-37; så godt som afskåret fra omverdenen på grund af de enorme snemasser. Hulvejen til Felsted var føget til, så man lige kunne se det øverste af elektricitetsmasterne. To bønderkarle måtte sørge for at mælken kom til mejeriet. Spandene blev læsset på en stor skovslæde forspændt et par stærke heste, og så gik det af sted, tværs over alle marker.

Hver dag måtte alle mand af hus for at skovle sne. De mødtes gerne i butik- 
ken, og hvis der blev købt en skovl, måtte mor have den under behandling ude i køkkenet. Nogle komfurringe blev raget til side og skovlen lagt hen over ilden for at blive varmet godt op, og så tog hun en stump stearinlys og gned den rigtig godt ind. Efter den omgang kunne skovlen slippe sneen, der ellers ville have klæbet sig fast.

Sneploven måtte i brug næsten hver dag. Den var lavet af solide planker og lignede nærmest stævnen på en båd. Kusken styrede hestene, og en medhjælper eller to gik bagved og holdt fast $\mathrm{i}$ et tykt reb for at sneploven ikke skulle skride ud til siderne og ende i vejgrøften.

Hele vinteren var fjorden frosset til. Isen blev tykkere og tykkere, og nogle benyttede lejligheden til at spadsere en tur til Aabenraa eller Løjtland. Der var blevet så underligt tyst, nu da vandets brusen og bølgernes skvulp ikke kunne høres.

Isbryderne »Store Bjørn« og "Lille Bjørn« havde travlt. En dag var nogle fiskere gået ud for at stange ål og opdagede for sent, at "Lille Bjørn« var i gang med at lave en sejlrende og havde afskåret dem tilbagevejen. Der var nu ikke andet at gøre end at stuve alt grejet på slæden og gå den lange omvej over til Aabenraa og videre med landevejen. Det var mørkt, inden de nåede hjem.

Frosten tog til, bed i ørerne og gav frostknuder på hænder og fødder. Det var meget pinefuldt, og værst var det, når der var gnavet hul på hælen, og fødderne skulle presses ned i træskoene. Vi ejede jo hverken skindforede støvler, rulamsluffer, pelshuer eller varmt, vatteret overtøj. Mor havde syet en pipaluk til os, en spids kyse af fløjl foret med flonel, der blev bundet under hagen, og den varmede dog altid noget. De, der var nødt til at opholde sig i længere tid udendørs, bandt et lag avispapir fast om kroppen uden på undertøjet. Det var et godt isoleringsmateriale til at holde den værste kulde fra livet.

Det var barske vintre, vi oplevede sidst i trediverne; også indendørs kneb det med at holde varmen. Frosten malede sine isblomster på vinduerne i soveværelserne, hvor temperaturen hele døgnet var under nulpunktet, og i køkkenet var der kun ild på komfuret om formiddagen, når middagsmaden blev kogt, eller der blev bagt franskbrød. Også i butikken var der halvkoldt. Døren gik jo op og i mange gange i løbet af dagen, og den store kakkelovn slugte en masse brændsel. Far måtte hver morgen $\mathrm{i}$ gang med blæselampen for at tø vandhanen op $\mathrm{i}$ vaskerummet, hvor gulvkluden hang på et søm og var stiv som et bræt.

Kun i stuen var der virkelig varmt og hyggeligt. Hele dagen gik jeg og glædede mig til, at vi om aftenen alle samledes omkring spisebordet med strikketøjet, avisen eller en bog. Mor havde jo altid sin stoppekurv at se til. Midt på bordet stod et fad med Filippa, Coxorange og Belle de Boskop fra vor egen 


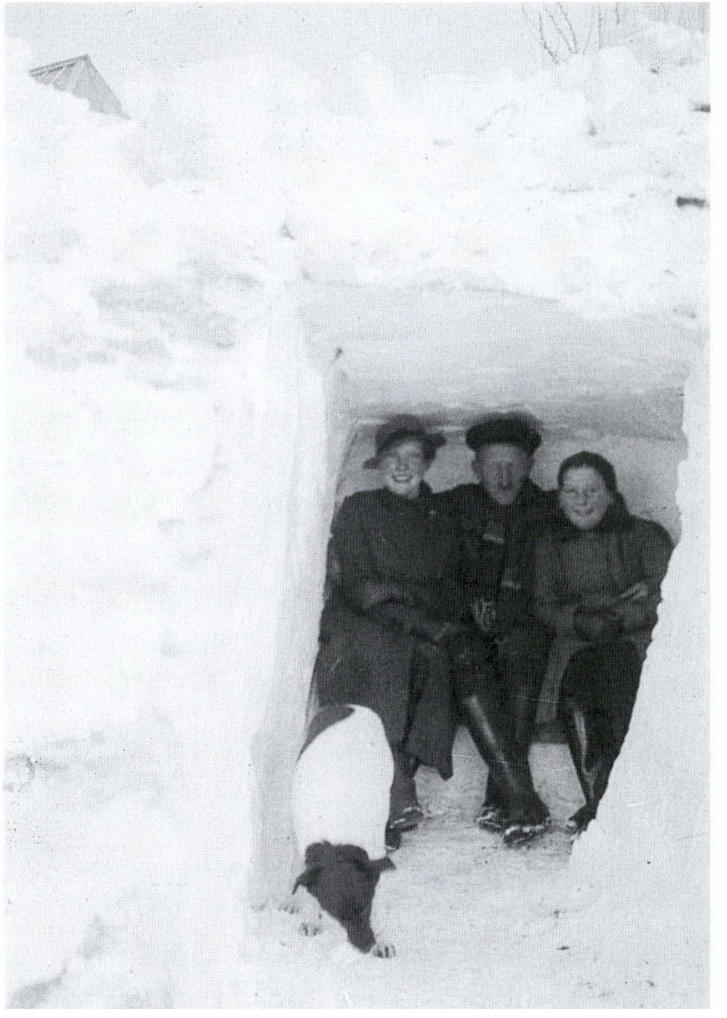

I vinteren 1936-37 blev Felstedskov helt afskåret fra omverdenen af de enorme snemasser. Overst til venstre anes husrygningen og til hojre toppen af et tra. Familien hygger sig $i$ snehulen. Fra venstre Marie, naboen fra "Hejskolen" og min sester Christine. Privateje.

have, og kaffekedelen snurrede gemytligt henne fra kakkelovnskrogen, - her var godt at være.

Far var snild til både at arbejde $\mathrm{i}$ træ, male og tegne. Vinteren 1936-37 lavede han et skilt til at hænge over skrivebordet, malede en blomsterranke derpå og skrev med fine, snørklede bogstaver:

»Lad Verden derude kun storme og larme.

Jeg søger min Fred ved Hjemmets Arne.«

Selv den længste vinter må engang give op og vige for foråret. Den 6. april, på fars fødselsdag, sejlede den sidste isflage ud af Aabenraa fjord med en flok fugle om bord, ... dagen efter var det tordenvejr.

"E Sommefolk"

Den følgende sommer blev en rigtig ønskesommer med solskin og varme, og nu var der liv og glade dage nede ved stranden. Efter fyraften kom de unge 
cyklende for at bade i det friske vand, der var så klart og rent, at man tydeligt kunne se, hvad der rørte sig på bunden. Velstillede borgere, "æ Sommefolk «, de fleste fra Aabenraa, var flyttet ind i deres sommerhuse.

Det betød ekstra travlhed, men også en god indtægt til købmanden. "Sommerfolket« tog det ikke så nøje med et par kroner fra eller til, og de købte ind af vin, øl, cigarer og chokolade, alt sammen ting, der for de lokale beboere var den rene luksus. Nogle gange kunne det godt virke lidt pinligt, når »æ Stajsfolk « stak hånden ned $\mathrm{i}$ bukselommen og halede en håndfuld penge op for at betale. Det skænkede de sikkert ikke en tanke; heller ikke når de stønnende klagede over, at det ikke var til at holde ud at ligge ved stranden og tage solbad $\mathrm{i}$ sådan en hede. Derfor ville de nu altså have nogle øller med hjem, som de kunne sidde og nyde i skyggen på terrassen.

Stod der tilfældigvis på samme tid nogle snavsede, svedige bønder eller tjenestefolk, udasede af høstarbejdet og hørte på de ubetænksomme byfolks beklagelser, gjaldt det om at være en god diplomat. Det var absolut ikke deres mening at ville provokere, de var bare i strålende humør. De ellers så adstadige, tilknappede borgere i vellønnede stillinger blev som kåde drenge, når de var sluppet væk fra byen, og nød rigtigt at gå $\mathrm{i}$ badebukser og med bare stikkelsbærben i sandalerne, - nogle lystige fætre. En eftermiddag, da de kom for at handle, betalte de med nogle våde pengesedler, som de havde været så heldige at få fisket op i båden igen, efter at de var fløjet fra dem på en rotur.

Damerne så vi knap så meget til. De blev nede ved vandet sammen med børnene og sendte mændene på indkøb.

\section{I plads ved landbruget}

Jeg havde nu været altmuligpige hjemme et par år og elskede at passe butikken, men skulle jo også gerne prøve noget andet.

Den 1.maj 1938 fik jeg plads ved landbruget, og det var nok meget fornuftigt, hvis jeg tænkte på med tiden at blive gift med en bonde.

Den lille landbofamilie: mand, kone, en dreng på to år og en gammel bedstefar boede lige over for bedstefar ved $æ$ vej, så jeg var ikke kommet langt hjemmefra. Længtes gjorde jeg nu alligevel, og når jeg om onsdagen gik »te høkkes« med en stor kurv æg, ønskede jeg mange gange, at jeg som før stod på den anden side af butiksbordet.

Bedstefaderen, hvor jeg tjente, var på aftægt. Den tid var forbi, hvor han kunne hjælpe til i mark og stald. Nu havde han den fornøjelse at være barnepige for drengen, hvis vi havde særlig travlt $\mathrm{i}$ høsten eller med roerne. Manden, konen og nu også jeg var fælles om alt arbejde. Hver morgen kl. 5, også om søndagen, ringede vækkeuret. Så var det bare med at få benene ud af sengen 
i en fart, inden jeg slumrede hen igen, for jeg havde langtfra udsovet, selvom jeg gik i seng kl. 9 om aftenen.

Malkningen var det første, der skulle ordnes. Køerne gik på græs temmelig langt fra ejendommen; vi måtte af sted i god tid for at blive færdige til mælkevognen kom og hentede mejerispandene. En lille klodset, tohjulet kærre blev læsset med malkespande, mejerispande og en si. Malkeskamlerne lå ude ved markleddet fra den ene gang til den anden. To af os blev "spændt for k kærren og den tredje skubbede bagpå, og så gik det op og ned ad bakke langs den ujævne markvej. Det samme gentog sig om aftenen. Et par køer blev også malket om middagen, og det var mit arbejde. Da var det ikke nødvendigt med kærren; jeg tog et åg på nakken med en spand hængende ved hver side $\mathrm{i}$ et reb, og når jeg kom hjem, blev mælken siet over $i$ en mejerispand.

Mange, mange ting skulle overkommes i løbet af dagen, både inde og ude. Når roerne skulle hakkes og udtyndes eller det var høsttid, blev der kun gjort det allernødvendigste ved den daglige rengøring. Markarbejdet var det vigtigste, og det gjaldt om at holde ud fra morgen til sen aften. Dyrene skulle jo også passes: høns, svin og kalve fodres og køerne malkes.

Om vinteren var der tærskning af korn, og roer der skulle hjem fra roekulen ude på marken.

Jeg havde fri hver anden søndag fra middag til sengetid. Ferie var et begreb, der ikke var kendt ude på landet. Min løn var det første halve år $15 \mathrm{kr}$. pr. måned plus kost og logi. Det næste halve år steg den til $20 \mathrm{kr}$. pr. måned.

Inden jeg flyttede hjemmefra, var Frits, min kæreste, som jeg nu turde kalde ham, rejst hjem til sine forældre, Anna og Friedrich Jessen på Frøslev Kaadnermark, der i mellemtiden havde klaret bedriften ved hjælp af en tjenestedreng. Frits - eller Frederik, som var hans rigtige navn - havde haft en lærerig plads hos vor dygtige nabo i et helt år, og jeg syntes det var ganske forfærdeligt, at jeg nu ikke kunne få ham at se hver dag. Om morgenen, som han skulle af sted, sad far og jeg i køkkenet og fik vor davre, da jeg pludselig slog hænderne for ansigtet og begyndte at tude. »Nej, høe no, de $æ$ da it noue o pief øve, han skal jo da it i ækri. Do kan væe sikke å, han kommer snart igjen«. Far fik ret. Søndagen efter, da jeg stod på udkig ved vinduet, kom Frits cyklende op ad »Hesselholt $\ll$.

En sommer og vinter havde jeg nu prøvet, hvor anstrengende det kunne være at arbejde ved landbruget og gøre karlearbejde. Sådan var det jo bare den gang, hvor der ikke fandtes alle de maskiner, man nu har til rådighed. Det havde dog ikke afskrakket mig fra at blive bondekone. Jeg var så ung og så forelsket, at jeg tror, jeg kunne have fulgt min kæreste til verdens ende. 


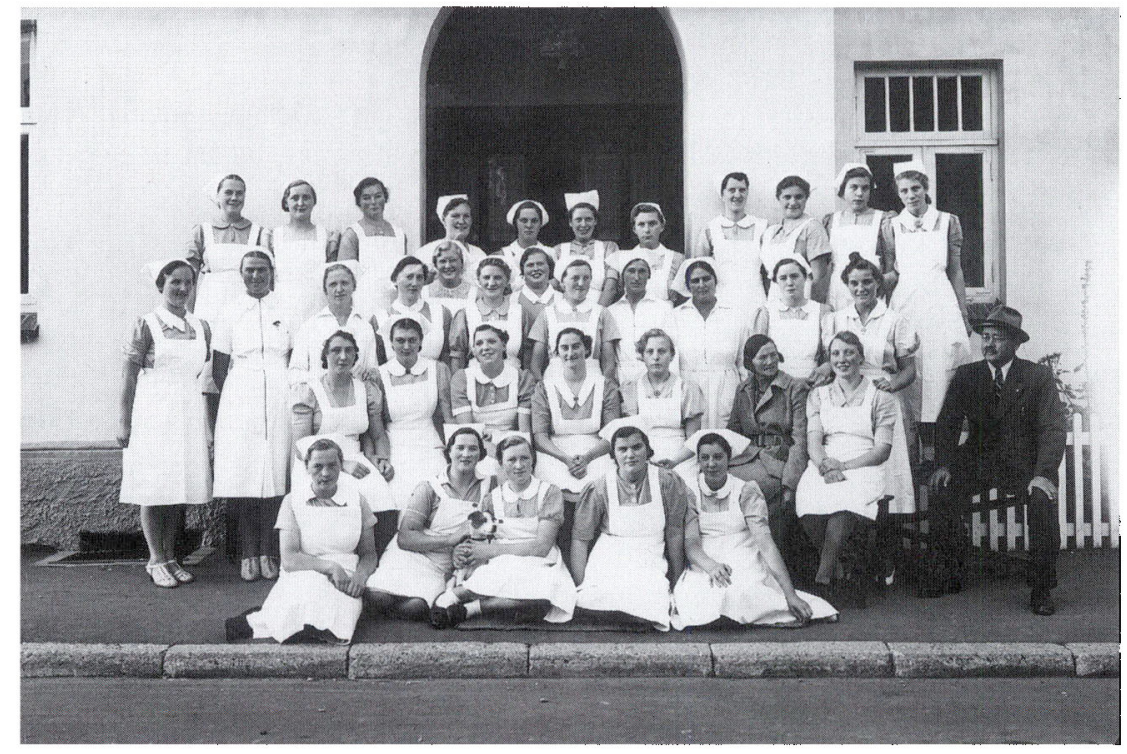

Eleverne på Gråsten Husholdningsskole 1939. Marie Jessen sidder yderst til hojre i anden rakke forfra. Forstanderinderne Olga Reppien og Ebba Drewes ses i 2. øverste rakke som nr. 3 og 4 fra højre. På stolen dyrlage Kold Christensen, som holdt foredrag på skolen den dag. Privateje.

\section{På Gråsten Husholdningsskole}

Madlavning var ikke min stærke side. Den gang jeg endnu var hjemme, kunne mor meget hurtigere få middagsmaden på bordet end jeg, og derfor blev jeg sat til at passe butikken, en ordning der i grunden passede mig storartet. $\mathrm{Da}$ jeg kom ud at tjene, var det også konen, der tog sig af gryderne; det eneste jeg kom til var at vaske kartoflerne og sætte dem over at koge, mens jeg gik ud på marken for at malke, og så pille dem, når jeg kom hjem. Ingen kan jo $\mathrm{i}$ længden nøjes med pillekartofler. Det måtte der gøres noget ved, og fra 1.maj til 1.oktober 1939 kom jeg på husholdningsskole i Gråsten.

Vi var 29 elever, der blev budt velkommen af forstanderinderne Olga Reppien og Ebba Drewes, vestjyden og københavneren, der var lige så forskellige som de egne, de kom fra.

Olga Reppien, den lille trivelige dame med det smukke ansigt, var den mest fremtrædende og myndige, der med vestjydens lune kom med den bemærkning, at hun ikke kunne vise sig $i$ et køkken, uden at det satte sig på sidebenene. Ebba Drewes var høj, spinkel, meget slank og charmerende, mere tilbageholdende og ikke nær så streng som sin kollega. Når vi havde månedsprøve i de fag, frk. Drewes underviste $i$, og måtte trække en seddel, var der altid nogle 
blanke imellem. Frk. Reppien rystede smilende og overbærende på hovedet sådan noget kunne hun aldrig finde på.

Den første skoledag blev vi inddelt i familier på fem eller seks medlemmer, hvor vi så hver uge skiftedes til at være madmoder, stuepige, bager, ordne vask og strygetøj, sy og strikke eller henkoge og sylte.

I det store køkken var der tre store, gammeldags komfurer, hvor der blev fyret med træ og briketter. Desuden et elkomfur, nærmest en kogeplade på lange, tynde ben, - en luksus, som ingen af os havde magen til derhjemme. På et bord stod en elovn, også noget helt nyt, der var kommet i handelen. I kælderen, hvor alt rengøringsmateriale var anbragt i mønsterværdig orden, fandtes en Nilfisk støvsuger, en nymodens tingest, som kun et par af pigerne havde stiftet bekendtskab med inden de kom på skolen.

Til at begynde med blev husholdningen ført efter en mands årsindtægt på $3.000 \mathrm{kr}$. og steg så i løbet af de $5 \mathrm{mdr}$. gradvis til $5.000,8.000 \mathrm{og} 10.000 \mathrm{kr}$ om året. Maden var lige god og nærende, blot med den forskel,at der ved den højere indtægt blev brugt luksusvarer, som f.eks. dyrt oksekød, vildt og fjerkræ, smør, fløde, vin, svesker, mandler o.s.v.

Kalderen var hvidkalket, også loftet, og på de to bjælker var der malet med røde bogstaver: »En plads til hver ting og hver ting på sin plads!«.

Skolen havde nogle bestemte regler. Hvis vi en aften blev inviteret $i$ byen, måtte vi pænt bede om lov til at gå, og fortælle, hvor vi skulle hen. Forstanderinderne ville vide, hvor de havde os. I særlige tilfælde kunne udgangstiden forlænges, men ellers skulle vi være tilbage senest kl. 22, og frk. Reppien gik ikke i seng, før vi alle var inden døre.

$\mathrm{Nu}$ må man ikke tro, at det kun drejede sig om orden og justits. Sådan en flok unge piger mellem 18 og 25 år var ikke længe om at sætte tingene i sving og skabe godt humør over det hele. Der skete altid noget nyt, ikke denne triste trummerum dag ud og dag ind. En formiddag kom en af pigerne farende ind: „Kronprinsesse Ingrid holder med sin bil lige uden for hoveddøren, og frk. Drewes står og taler med hende. « Du godeste, $-\mathrm{i}$ løbet af nul komma niks var det store køkken som blæst. Og så kom kronprinsessen slet ikke indenfor; hun havde bare afleveret en kort besked. Ergerligt, vi havde sådan glædet os til at se hende på nært hold.

Jo, sommeren på Graasten Husholdningsskole var en spændende, uforglemmelig tid. Alene den friske start på dagen med morgentur, hvor vi i lyseblå kjoler og hvide forklæder og med hvide, stivede kapper på hovedet, syngende marcherede ud gennem byen, var en oplevelse. Eller når vi i de lyse, lune sommeraftener hyggede os ude $\mathrm{i}$ haven, og inden vi gik hver til sit sluttede dagen med at synge: "I skovens dybe, stille ro«.

Men så kom der en dag, hvor denne ubekymrede tilværelse med eet blev 
bragt til tavshed. Noget mørkt, truende fik den glade latter til at forstumme: Krigens udbrud den 3. september 1939. Frk. Reppien kom tidlig om morgenen og fortalte, at det, vi alle i nogen tid havde frygtet, nu var blevet barsk virkelighed. Hun græd af sorg og harme over »denne onde skurk «. To dage forinden havde »die Wehrmacht« overskredet grænsen til Polen. Det måtte jo ende med krig overalt, hvis Hitlers magtbegær og den tyske indmarch i det ene land efter det andet skulle stoppes.

Tiden ilede af sted, og dagen, hvor vi måtte sige farvel til skolen, nærmede sig. Forhåbentlig var vi blevet en hel del klogere i de 5 måneder. Ved afskeden holdt Olga Reppien en tale, hvor hun bl.a. sagde: "Frk. Drewes og min samt de tre lærerinders opgave har været at lære fra os, at fylde på. Nu er det op til jer selv at drage nytte af det, I har lært«.

Graasten Husholdningsskole er forlængst ude af bybilledet. Skolen med den smukke indskrift over hoveddøren:

»Vaagent Virke i Hverdagsdragt

skal være vort Løsen som Grænsevagt!«

har måttet vige pladsen for tidens udvikling.

\section{Enepige $i$ huset}

Min søster, Christine, var nu også blevet konfirmeret og havde overtaget stillingen som altmuligpige derhjemme. Mor mente, at jeg efter opholdet på husholdningsskolen var helbefaren nok til at få en plads som enepige $i$ huset og vise, at jeg kunne andet og mere end koge pillekartofler. Jeg var ikke særlig stolt ved disse udsigter, men kunne jo ikke være bekendt at sige det. Mit største ønske var at få en plads i nærheden af Frits' hjem, så han ikke hver anden søndag behøvede at cykle to gange $30 \mathrm{~km}$ for at besøge mig hjemme på »Hesselholt«.

Det ønske fik jeg opfyldt, og den 1 .november cyklede jeg til Nørregade i Padborg for at begynde $i$ min nye plads hos en familie med tre børn og to unge butiksmedhjælpere. Der var nemlig både boghandel og Tatoludsalg. Fru Møller tog imod mig og viste mig vej op ad tre trappeafsatser og hen over en åben loftsplads til det lille kvistværelse med skråvægge, der nu skulle være mit. Der stod en tremmeseng, et lille bord, en stol og min kommode, der var blevet sendt i forvejen. Desuden var der et vaskestativ med et emaljeret vaskefad og en vandkande. På loftet lige uden for døren stod et klædeskab, hvor jeg kunne hænge mit tøj.

Det var der dog ikke tid til nu; det måtte vente, til jeg havde vasket op efter middagen. Først skulle maden laves, familien plejede at spise om aftenen. Jeg fik besked på at slagte og rense en stor kogetorsk, heldigvis et arbejde som jeg havde prøvet mange gange før, når bedstefar ved æ vej kom med sine fisk. 


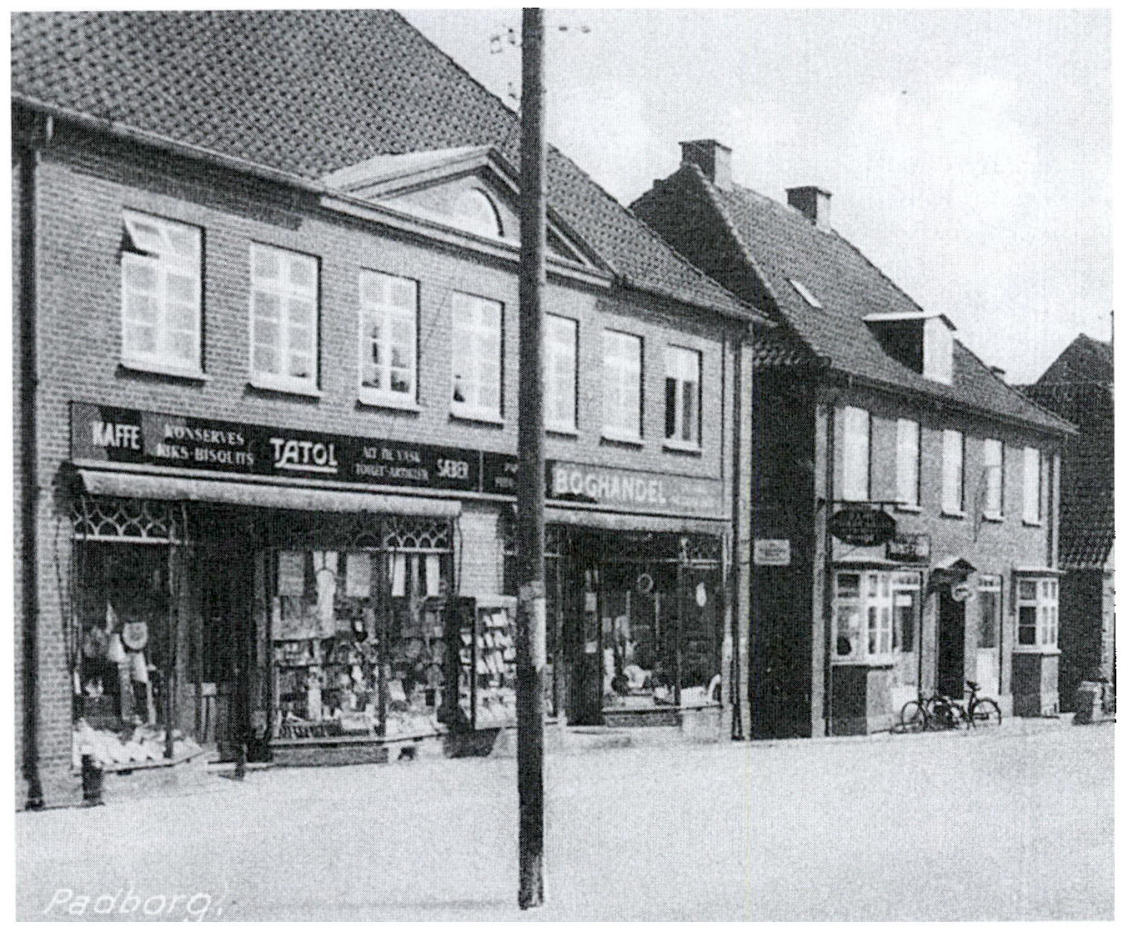

I boghandler Mollers hjem i Norregade i Padborg ovenpå boghandelen og tatoludsalget var Marie Jessen enepige i huset $i$ 1940. Postkort ca. 1936. Privateje.

De første par dage tog fru Møller selv del i husførelsen, og dygtig, det var hun. Hun viste mig til rette og forklarede, hvordan tingene var tilrettelagt, når jeg var alene om at klare det hele. Foruden at tage sig af børnene, tre søde og velopdragne piger på tolv, ti og fem år, ekspederede hun i Tatoludsalget sammen med den unge pige og holdt styr på indkøb og regnskab. Om eftermiddagen sad hun og syede på et rya gulvtæppe til dagligstuen.

Møller var alene om boghandelen med en ung mandlig lærling til hjælp. Man kan vist roligt sige om Møller, at han var lidt af en professortype, klog og alvidende, men ubehjælpsom i alt, hvad der angik det praktiske - en godmodig og venlig mand. Alt det praktiske ordnede fru Møller, og hendes dygtighed og energi fik mig til at blive nervøs og usikker.

Den vinter sled jeg hul på strømperne, ikke på hæl og tå, men på knæene af at ligge og vaske gulv. De to unge butiksmedarbejdere fik både kost og logi, og deres værelser skulle jeg også holde $i$ orden. I alt var der otte senge at rede hver dag, og nede i kælderen ventede en lang række sko og fedtlæderstøvler på at blive pudset. De to største piger fik madpakke med i skole; der skulle 
støvsuges, laves mad, vaskes op o.s.v. i een uendelighed. Om eftermiddagen, når der var lidt tid tilovers, stod jeg midt om vinteren oppe på loftet og malede havemøbler. Fingrene var så stive af kulde, at det kneb med at holde fast på penselen.

Nu må man huske på, at for 50 år siden var tiderne anderledes for tjenestefolkene. Ingen kunne drømme om at protestere. Det, man fik besked på at lave, blev gjort uden indvendinger, og sådan var det alle steder. Heldigvis blev jeg stædigt ved at mase på og gøre min pligt. Med tiden gik det lettere fra hånden, og jeg blev glad for at være i min plads.

Det var en skrækkelig kold vinter det år. Da kunne man virkelig sige som H.C. Andersen: "Det frøs, så det knagede i isskorpen«. Der var begyndt at komme rationeringer på både det ene og det andet, også brændsel. Med den tildeling der var, kunne centralfyret ikke opvarme det store hus til mere end $14-16^{\circ} \mathrm{C}$. Oppe på mit værelse var der ingen radiator og heller ikke mulighed for anden opvarmning. Vandkanden på vaskestativet var bundfrossen. Jeg var nødt til at vaske mig nede i køkkenet om morgenen. Skosværten var også blevet til en isklump. Jeg hundefrøs, når jeg krøb i seng om aftenen, og var lige så kold, når vækkeuret ringede om morgenen.

$\mathrm{Nu}$ bagefter begriber jeg ikke, hvorfor jeg ikke spurgte mor om en varmedunk og et tæppe, da Frits og jeg var hjemme på besøg 1. juledag. Mor, der ellers huskede på alt, anede nok ikke, hvor isnende koldt der var i mit kammer.

\section{Besattelsen}

Nå, en vinter får jo ende engang. Foråret kom med lyse dage og lyse forventninger.

Disse lyse forventninger fik en brat afslutning med een af de mørkeste dage i Danmarks historie. Den 9. april 1940, meget tidligt om morgenen, omkring kl. 5, bankede fru Møller på min dør: „Iversen, skynd dig at stå op, tyskerne er her, og tre af grænsegendarmerne, vore gode venner, er blevet skudt nede ved viadukten."

Søvndrukken tumlede jeg ud af sengen. Jeg havde nok om natten hørt en brummende lyd, men sov bare videre uden at ane, at det var den tyske Luftwaffe, der fløj ind over Danmark. Også alle de andre i huset var blevet vækket, og vi samledes i spisestuen. Møller plejede hver morgen at bede bordbøn og læse et kort afsnit af bibelen højt, inden vi fik morgenmad.

Denne morgen, den 9. april 1940, glemmer jeg aldrig. Mens den tyske Wehrmacht med kampvogne, tanks og store lastbiler rullede op ad Nørregade i Padborg for at tage hele Danmark i besiddelse, holdt han en gribende andagt og sluttede med at bede Gud holde sin beskyttende hånd over fædrelandet og os alle. Af fru Møller fik vi tre unge besked på at forsøge, om det var muligt 


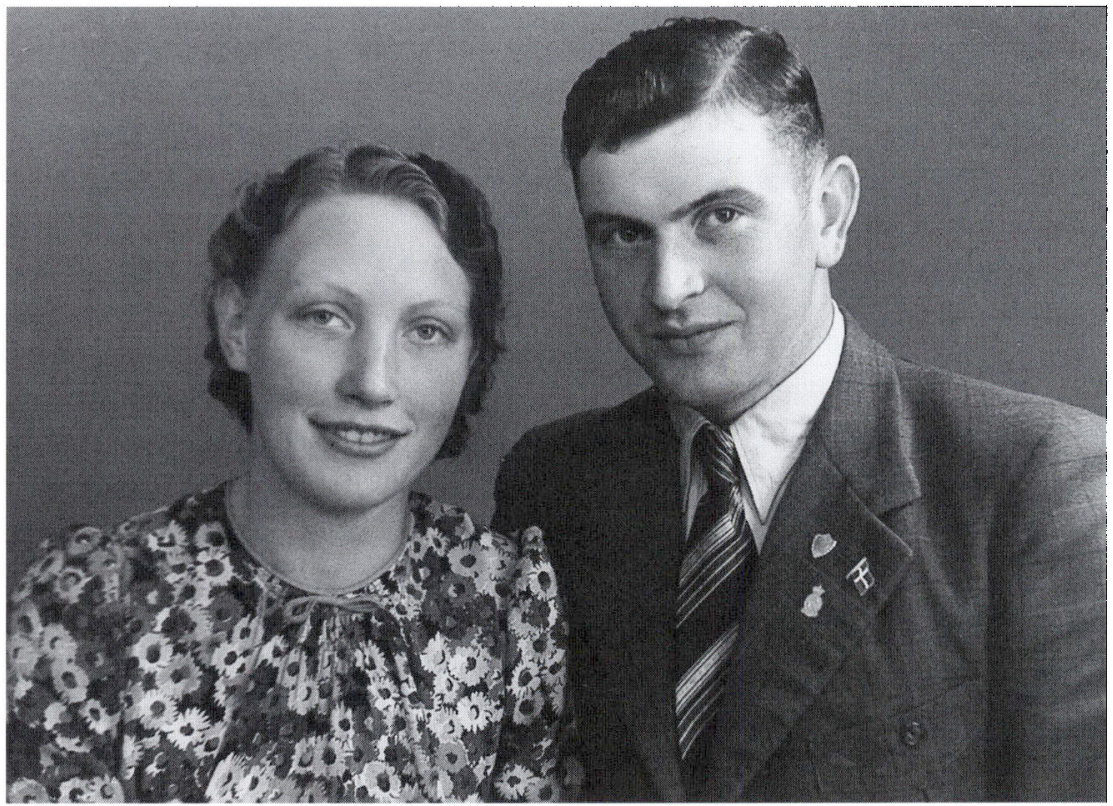

De nyforlovede $i$ sommeren 1940. På reversen barer Frederik Jessen Dannebrog, Kongenålen og et idratsmarke. Privateje.

at få en telefonsamtale igennem til vore forældre, så de vidste, at vi alle var $\mathrm{i}$ god behold. $\mathrm{Al}$ anden trafik var standset, ingen vovede sig uden for døren.

De tyske soldater regnede ikke denne invasion for noget særligt. På en af lastbilerne sad en flok og sang til musik fra en mundharmonika. Vi andre græd af sorg og harme, undtagen selvfølgelig de, der sympatiserede med fjenden, - de jublede af begejstring. En kone fra Felsted sogn bød »Volksgenosserne« velkommen med denne hilsen:

»Wie var ess gut, daß ihr kaem,

vi hæ vint edde jæ sålæeng, sålæeng.« ...

Det havde alle vi andre bestemt ikke, og godt var det, at vi på det tidspunkt ikke havde nogen anelse om, at der ville gå fem onde år, hvor vi måtte rette os efter Hitlers og besættelsemagtens forgodtbefindende.

Fra den ene dag til den anden blev der vendt op og ned på næsten alt $\mathrm{i}$ de vante omgivelser. Overalt grønne uniformer, støvletramp og det forhadte sprog.

På hver side af gaden under viadukten i Padborg stod en vagtpost for det tilfælde, at der ville blive gjort forsøg på at sprænge jernbanebroen i luften og dermed hindre tyskerne i at køre krigsmateriel til Danmark. 
Når det blev aften, rugede mørket over land og by, sorte rullegardiner for vinduerne og mennesketomme gader. Cykellygterne blev også mørkelagt. De fik en sort hætte over, hvor lidt lys sivede ud gennem en smal sprække på størrelse med den, der er i en sparebøsse. Den eneste gavn man havde af lygten var, at man lige kunne skimte en modgående cykel. Biler behøvede man ikke at tage sig i vare for, det var kun sjældent, der viste sig en på landevejen. Tyskerne lagde beslag på alt, selvfølgelig også så vigtig en ting som benzin. Erhvervsdrivende, som var afhængige af bilen, fik stillet an med en gasgenerator, som blev fyret op med træ, generatorbrænde, der skulle være godt tørt.

Når et sådant køretøj kom kravlende op ad bakken med den sorte røg vældende ud af skorstenen, hændte det tit, at den gik i stå og der måtte ekstra skovlfulde brændsel på. Mælkemanden i byen klarede sig på en anden og nemmere måde. Han spændte simpelthen en hest for sin bil. Lotte var nem at starte, osede ikke og var billig i drift. Det var dengang vi alle sang med på visen:

"Lotte hopper som en ged, gade op og gade ned, hun er hele byens store kærlighed« o.s.v.

Varerne forsvandt hurtigt fra butikkerne, hylderne stod tomme, værnemagten kunne bruge det hele og kun få forretningsfolk vovede at protestere - det gavnede heller ikke det mindste. Blandt befolkningen var der blevet hamstret i stor stil af alt muligt, især det, der kunne tåle at opbevares i længere tid. Inden ret længe kom der rationering på så godt som alle dagligvarer.

Vi fik udleveret rationeringskort med små mærker til alle personer $i$ husstanden, og det gjaldt om at få det til at slå til indtil næste udlevering. Det drejede sig om kaffe, brød, hvedemel, kartoffelmel, gryn, smør, margarine, sukker og sæbe. Desuden var der ekstra rationeringskort til brændsel, tekstil og sko. Nogle ting var så godt som umulige at skaffe, bl.a. sydfrugter og tobak. For rygerne var det nærmest en katastrofe, men "nød lærer nøgen kvinde at spinde«. De tobakshungrende gav sig til at avle tobaksplanter, og det var ikke noget særsyn at se en lang række tobaksblade hængt op på tørresnoren. Kød og flæsk var ikke rationeret. Det var heller ikke nødvendigt, for det blev beslaglagt af værnemagten, inden det nåede ud til slagterforretningerne.

Et lyspunkt i al denne rationeringstid var, at der var nok af mælk, æg, kartofler og andre grønsager. Ellers måtte vi tage til takke med erstatningsvarer. I stedet for kakao kunne der købes et pulver, der hed »Sanade«, som blev helt lilla, når det blev rørt ud i mælk. Kaffeerstatning havde ikke meget tilfælles med kaffe, krydderier lignede savsmuld og smagte derefter, og håndsæben, der overhovedet ikke kunne skumme, var som et stykke gråt cement. Sådan var der så meget vi måtte give afkald på i denne tunge, usikre tid. På den 
anden side var der meget værdifuldt, noget der gjorde, at menneskene kom hinanden ved på en helt anden måde end før. Der var ikke den store afstand mellem land og by, rig eller fattig. "Vi var jo alle i samme båd «.

I løbet af vinteren cyklede jeg mindst een aften om ugen ud til Frits og hans forældre. Her var så hyggeligt og varmt i den lille stue, når tørveilden buldrede i kakkelovnen. Hen på aftenen fik vi en kop "kaffe« og et stykke franskbrød, og så fulgte Frits mig hjem til gadedøren. I midten af marts måned blev vi ringforlovede.

En uges tid før maj sagde fru Møller, at det ville glæde både hende og familien, hvis jeg havde lyst til at blive hos dem i hvert tilfælde et halvt år længere. Men jeg sagde nejtak til dette venlige tilbud og valgte i stedet at tage hjem til Felstedskov. Frits og jeg var nemlig i forvejen blevet enige om at jeg ikke skulle blive i pladsen, da jeg muligvis ville få endnu mere at se til, når haven skulle holdes i orden om sommeren. Når jeg rejste, kunne vi ganske vist ikke ses så tit, men han regnede ikke de 30 kilometers afstand for noget videre. Det tog allerhøjst to timer på cykel, og jeg kunne også sagtens cykle til Frøslevmark. Kærlighedsvejen er aldrig for lang.

Den 1. maj sagde jeg farvel til Padborg og satte kursen nordpå, hjem til Hesselholt. Christine, der havde været pige hjemme et par år, ville også nok prøve noget andet og fik plads på den ejendom, hvor jeg havde tjent. Hun havde et helt andet "Gåpåmod« og kunne sagtens klare sig. For mig var det herligt at vågne om morgenen og se ud over vandet, igen stå bag butiksbordet og møde alle de kendte ansigter.

Desværre var alt jo heller ikke her, som det før havde været. Det var ikke altid lige rart, når varerne slap op eller en kunde ikke havde flere rationeringsmærker. Nogle troede, at hvis de bare pungede godt ud, kunne de få mere end andre. Så blev far vred, - ikke tale om at han ville lade sig bestikke. Der var hajer nok, der tjente tykt på sortbørshandelen, og bønder der om natten slagtede "sorte svin« til tyskerne for en stor overbetaling. En dag, da jeg var alene hjemme, kom en nabo og ville købe cigaretter. Hvad skulle jeg gøre? Der var ingen, men han påstod at det var løgn og skældte ud, så jeg var lige ved at græde. Dagen efter kom han dog og undskyldte sin hidsighed.

Ikke ret langt fra Hesselholt ligger som sagt Felsbæk Mølle, hvor der for en del år siden var både mølleri og landbrug. Vandet fra mølledammen løb gennem to store cementrør under vejen, brusede som et lille vandfald, kaldet »æ Friskøtt «, ned over en dynge store kampesten og endte et par hundrede meter længere fremme ude i fjorden. Omkring 1940 begyndte det at gå tilbage for mølleriet, landbruget var blevet mere mekaniseret, og hver bonde havde fået kværn og malede selv kornet.

Derfor besluttede Matthias Walsted at lade mølledammen afvande, så are- 
alet kunne benyttes til græsmark for ungkreaturerne. Den bageste og største del af dammen var et ufremkommeligt, bundløst morads, tilgroet med krat, siv og rør; i daglig tale kaldt »æ uen Æend « (den onde ende).

En sommerdag i 1941 blev der med eet mere livligt i vor lille landsby. En flok unge fra hele landet, $i$ alt 85 gymnasiaster, arbejdere, håndværkere og studenter under ledelse af pastor Peter Gadeberg fra Ensted, gik i gang med afvandingen, et omfattende arbejde, der varede helt til efteråret. Alt, hvad der skulle bruges af kolonialvarer, blev købt hos os, og det var ikke småting, en sådan flok unge fyre kunne sætte til livs.

Far overlod regnskabet med penge og de mange rationeringsmærker til mig; det var nemmere, når kun een tog sig af det.

Egentlig ved jeg ikke, hvor disse unge mænd kom fra, men der var i hvert fald københavnere iblandt, og de forstod selvfølgelig ikke et muk af den sønderjyske dialekt. $\mathrm{Da}$ der en morgen kom et par stykker af dem og bestilte 10 rugbrød og 6 franskbrød, telefonerede jeg til bageren, afgav bestillingen og bad om at få varerne sendt med »æ Merrabil«. Forundret spurgte de, hvordan i alverden denne bil så ud, for sådan en havde de da hverken set eller hørt tale om i København. »E Merrabil«, forklarede jeg, er såmænd bare rutebilen, der kommer hertil om middagen.

Jeg havde ellers, halvvejs i spøg, sagt til Matthias Walsted, at hvis han gjorde alvor af afvandingen og dermed ødelagde noget af den skønne udsigt, som jeg holdt så meget af, så flyttede jeg. Og det blev virkelig til alvor. Ikke på grund af mølledammen, men fordi Frits og jeg blev gift i oktober 1942, og mit fremtidige hjem blev på Frøslev Kaadnermark, langt væk fra vand og bøgeskov $\mathrm{i}$ et helt andet landskab, smukt på sin måde, med granskov og lyngpolde.

\section{Nygift på Froslev Kaadnermark}

Sommeren forud for brylluppet var stuehuset blevet indrettet med aftægtsbolig til mine svigerforældre; det var dog kun en stue og et soveværelse. Hele husholdningen havde vi fælles, og de blev ved med at arbejde, som de altid havde gjort, så på den måde skete der overhovedet ingen forandring i hverdagen undtagen den, at vi nu var fire om at klare bedriften.

Foruden at indrette aftægtsstuerne fik hele huset en ansigtsløftning. Der blev slået masonitplader under loftet $\mathrm{i}$ de to stuer, den lille runde kakkelovn blev skiftet ud med en hjørnekamin, og der blev lagt bræddegulv oven på cementgulvet i soveværelset. I køkkenet fik vi terrazzogulv i stedet for det ru, revnede cementgulv, der ikke var til at skrubbe rent. Også det gamle fritstående komfur blev kasseret og et mere moderne med en god bageovn indmuret. Der var ikke en gang en gruekedel i vaskerummet, og en storvask uden sådan en 


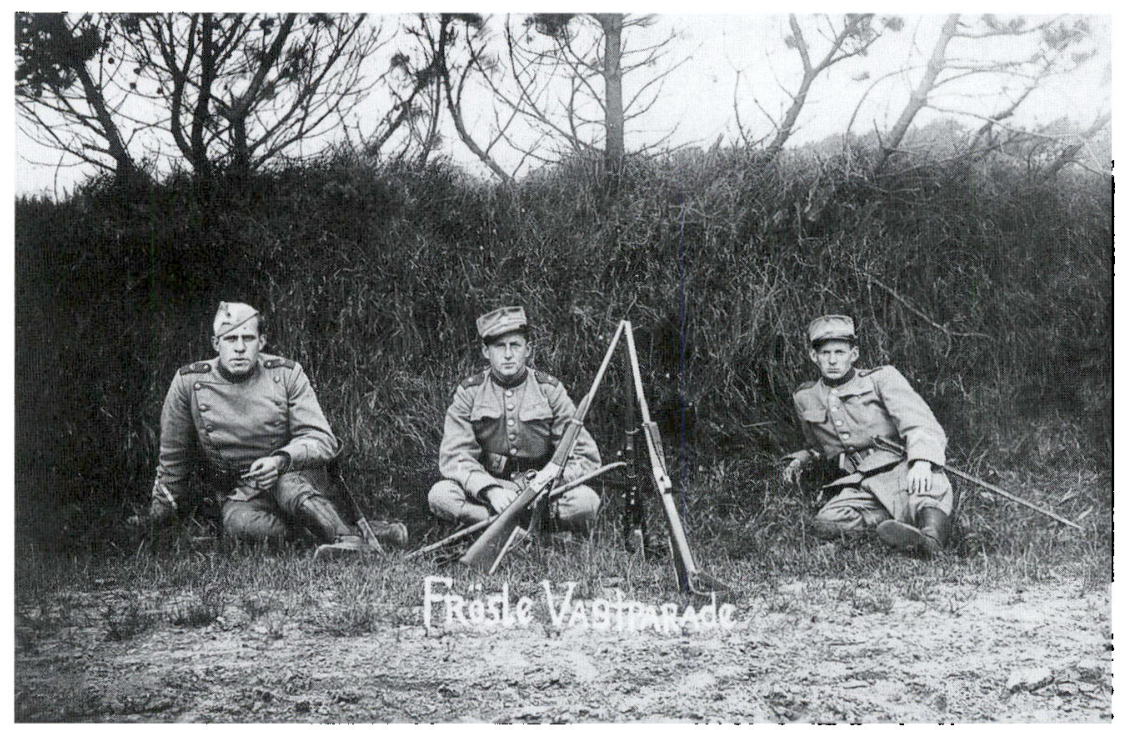

Gendarmerne var af stor betydning for livet i Bov sogn. Her poserer "Froslev Vagtparade» for fotografen. Bov lokalarkiv.

brune karme og blanke gulve. Udenfor var døre og vinduer malet rustrøde og flødefarvede - noget helt nyt. Alle andre ejendomme havde grønt træværk.

Brylluppet blev fastsat til den 11 . oktober, og dagen forinden kom kogekonen, som mor havde bestilt nogen tid i forvejen. Den gang var der ingen, der ejede en fryseboks, og derfor måtte alle forberedelser angående madlavningen vente længst muligt. Suppen skulle jo nødigt stå og blive sur. Rundt omkring i haverne stod roserne endnu i flor på denne ualmindeligt milde efterårsdag, da vi blev viet i Felsted Kirke af pastor Mikkelsen, hos hvem jeg jo også var blevet konfirmeret.

Vi holdt ikke noget stort bryllupsgilde derhjemme. Foruden mine svigerforældre var der kun de nærmeste af min familie. Al Frits's familie boede i Bov sogn, og det var alt for lang en vej enten at cykle eller køre med hestevogn frem og tilbage samme dag. Dem holdt vi derfor en lille fest for på Frøslevmark en uges tid efter brylluppet. Vi fik mange fine gaver fra forretningsforbindelser. Hele kundekredsen havde skillinget sammen til en stor gave, og de blev naturligvis alle indbudt til kaffebord og "Balle Punch« bagefter. Lærer Petersens tilbød os at låne skolestuen, og der var så mange gæster, at de måtte fordeles over tre aftener.

Disse tre uforglemmelige aftener var dog ikke uden mislyde. Pludselig hver aften kom denne uhyggelige, gennemtrængende tone, som vi kendte alt for 
godt - Luftalarm! I løbet af et øjeblik forstummede al munter snak. Forældre, hvis børn var alene hjemme, rejste sig straks fra bordet, bød hastigt "godnat" og tænkte kun på at komme hjem så hurtigt som muligt, selvom det ikke var helt ufarligt at vove sig udenfor. De fleste gæster blev, indtil luftalarmen blev afblæst, og vi atter kunne ånde lettet op.

Efter festlighederne pakkede Frits og jeg bryllupsgaverne i et par store kasser, bandt dem forsvarligt fast på cyklernes bagagebærer og begav os på vej til Frøslevmark. Der stod de, midt i den åbne dør, både hans far og mor og tog imod os, gav mig hånden og bød mig velkommen i mit nye hjem. Et nyt og helt anderledes livsafsnit var begyndt. Hverdagen mødte op med sine krav, men også med mange glæder.

Egentlig er det mærkeligt, men det sker tit, at unge mennesker til at begynde med bliver udsat for modgang, og det er bestemt heller ingen skade til men kan tværtimod være gavnligt. At begynde altfor godt og nemt er ikke det bedste. Vi slap heller ikke for denne lære.

Der var næsten ikke faldet regn om sommeren, og høstudbyttet var af den grund blevet meget ringe på den sandede jord. Om vinteren blev fire slagterisvin syge og døde, og en so døde fra et kuld smågrise. Det var et stort økonomisk tab; den eneste indtægt var næsten kun mælkepengene fra mejeriet og så ægpengene, der kunne dække udgifterne til købmandsvarer. Kreditforeningsrenterne skulle betales, og de var jo lige store, uanset hvor lidt vi fik for landbrugsvarerne. Det gjaldt frem for alt om at få pengene skrabet sammen til »Fandens Fødselsdag«.

Endnu to tørre somre fulgte efter den første og det gik hårđest ud over den magre jord, som vi desværre havde mest af. Ikke en øre blev givet unyttigt ud, og vi klarede at betale enhver sit uden at optage et nyt lån.

Endelig begyndte det at gå fremad - »Efter regn kommer solskin «. I dette tilfælde heldigvis omvendt og det gjorde, at høsten den følgende sommer fyldte godt i laden. Alle landbrug havde både heste, køer, svin og høns. Ikke sådan som nu, hvor mange er gået over til kun at have een af delene, hvad der sommetider kan betyde knald eller fald. Da var risikoen ikke så stor ved den gammeldags metode; når det ene slog fejl, var der altid en mulighed ved det andet. Vi havde to heste, syv køer, nogle ungkreaturer og kalve, en eller to søer og to stier til slagterisvin foruden et hønsehus med 30-40 høns.

Mine svigerforældre var et par rare, hjælpsomme og flittige mennesker. Svigermor var ikke ret høj, men hvad hun ikke havde i højden, det havde hun $\mathrm{i}$ drøjden - en rigtig bondekone, der kunne bestille noget. Hun malkede, så det svuppede i spanden. Der kunne jeg ikke følge med. Hun var også god til at lave mad, men den daglige rengøring gjorde hun ikke meget ved. Hækling var hendes hobby, og det var flotte ting, hun lavede. 
Svigerfar var mager og krumbøjet, men alligevel stærk, sej og udholdende. Han havde - ligesom min far - været indkaldt $\mathrm{i}$ krigen 1914-18 og var, da han kom hjem, meget svag og træt af den sygdom, som blev kaldt Grippe, en svær form for influenza. Ellers var han uskadt, men sorg og elendighed ventede ham ved hjemkomsten.

Hans mor og den yngste af sønnerne var alene tilbage på ejendommen. Denne kone må have været $i$ besiddelse af et utroligt stærkt sind. For år tilbage var en tolvårig søn druknet $\mathrm{i}$ en mergelgrav. $\mathrm{Nu}$ var to sønner faldet $\mathrm{i}$ krigen og een kommet dødssyg hjem fra fronten. Da han også døde, blev det for meget for hendes mand. Han døde kort efter af sorg over tabet af sine drenge. Tilbage var nu tre sønner og tre døtre. Dengang havde de fleste familier mange børn. I min svigermors barndomshjem havde de været seks drenge og fem piger. Alle drenge døde som små af en sjælden, ukendt sygdom. Hvad har denne mor ikke måttet gennemgå, hver gang hun fødte en søn.

Mine svigerforældre blev gift lige efter krigen og overtog ejendommen, og hans mor blev boende hos dem indtil sin død i 1935 . Hendes mand, der jo døde inden Genforeningen, var blevet begravet på Hanved kirkegård i Tyskland. Det ønskede hun ikke og havde forlængst bestemt, at hun ville begraves på kirkegården i Bov. Nu var det så Frits og mig, der skulle føre bedriften videre. Han havde ingen søskende.

Vore marker lå meget spredt, bl.a. var der bagved Frøslev Savværk en mark, som blev kaldt "Agerende«, og navnet passede meget godt. Den lå nemlig lige ind til skoven og det var mest flyvesand, egentlig ikke værd at dyrke som agerjord. Men vi var ikke så forvænte, det hele skulle tages med. Helt ude ved Frøslev Polde, hvor vejen fra Frøslev gik lige igennem skoven til Faarhus, havde vi 10 ha, hvoraf halvdelen lå hen som lyngpolde og granskov. Til ejendommen hørte også eng og mose, næsten en hel mil længere mod sydvest.

Enhver der har arbejdet ved landbruget, ved jo hvor meget der er at tage vare på med jord og besætning hele året rundt. Det hele var mere møjsommeligt, den gang vi ikke havde alle de maskiner og redskaber, der er til stor lettelse, ikke mindst for kvinderne. Hvor een mand nu kan klare høsten med en mejetærsker, måtte vi ofte tage del $\mathbf{i}$ arbejdet på en måde, der egentlig overskred vore kræfter.

Jeg har altid godt kunnet lide at hakke og tynde ud i roerne, men var slem til at gå krumbøjet og få ondt $\mathrm{i}$ ryggen. Det gjorde Frits ikke, og når jeg sakkede agterud, hakkede han rask et stykke af min række, så jeg nåede op ved siden af ham.

Vi gik og snakkede, mens vi byggede luftkasteller. - - - Bare jordfordelingen snart ville komme i gang. Måske kunne vi få de marker, der lå ganske tæt ved 
vor ejendom og tilhørte nogle bønder i Frøslev By. Jorden var bedre, og vi gav gerne et større areal i bytte. Der gik dog en del år, inden det blev til noget med jordfordelingen, en vanskelig opgave, hvor det var svært at gøre alle tilpas.

Enghøsten og tørvegravningen faldt næsten altid sammen med roehakningen. Når de to mandfolk arbejdede ude i engen eller mosen, kørte de af sted meget tidligt om morgenen og vendte først hjem hen på aftenen. Der skulle pakkes en ordentlig portion mad til hver dag. Foruden en stor stabel rundtenommer med fedt, pølse og ost, var der et fad med rødgrød, flasker med mælk, kaffe, saftevand eller hjemmebrygget øl. Tallerkener, kopper og skeer måtte endelig ikke glemmes.

Det hjemmebryggede øl blev lavet af vand, sukker, "Gambrin« og gær, og jeg kogte gerne en god portion ad gangen. Det smagte godt, men kunne ikke gemmes ret længe, uden at det blev surt. Når vognen skumplede langs den puklede, ujævne vej til eng og mose og øllet blev rystet, fløj propperne sommetider af flaskerne med et knald.

Engang, da de to mandfolk trængte til en bid brød, fik de en ordentlig forskrækkelse. En hugorm havde fundet vej op i kurven og lagt sig godt til rette oven på det hele. Om aftenen, når de kom hjem med et læs hø, fik jeg fat i madkurven for at gøre den parat til næste dag. Hø og støv var klistret fast i tallerkener og rødgrødsfadet, så det måtte sættes i blød inden opvasken.

Det var Frits og mig, der plejede at vende tørvene og sætte dem i stakke. En sommer var det så frygteligt hedt ude på mosen, at jeg hverken kunne spise eller drikke. Solen brændte hele dagen, fluer og myg svirrede rundt om ens hoved og stak ubønhørligt. Jeg havde uldne, strikkede luffér på, for ellers varede det ikke længe, før der var slidt hul på fingrene af de hårde, kantede tørv. Mine hænder var så opsvulmede af varmen, at de lignede boksehandsker. Først om aftenen, da vi cyklede hjem og holdt et lille hvil i skyggen, fik jeg lidt at spise. Imens sad jeg og tænkte på hvor rart det var, at når vi kom hjem, havde »de gamle« ordnet alt med malkning og fodring. Vi kunne holde fyraften, sidde ude $\mathrm{i}$ haven og nyde den dejlige sommeraften. - Al møje og besvær var glemt.

Vi havde en stor køkkenhave og mange frugtbuske. Også her hjalp mine svigerforældre, når bærrene var modne. Efter fyraften har jeg tit siddet $\mathrm{i}$ haven og plukket ribs og solbær indtil det blev mørkt. Næste morgen blev de vejet og bragt ud til dem, der havde bestilt. Vi brugte selv mange bær til saft og syltetøj, og der var alligevel gerne $60 \mathrm{~kg}$ tilovers til salg.

$\mathrm{Nu}$ da hø og tørv var kommet $\mathrm{i}$ hus, stod kornhøsten for døren. Mine svigerforældre havde heldigvis købt selvbinder for nogle år siden. Der skulle helst tre heste til at trække den, og det blev ordnet på den måde, at vi lånte naboens hest og til gengæld høstede hans korn med vor selvbinder. Var det en 


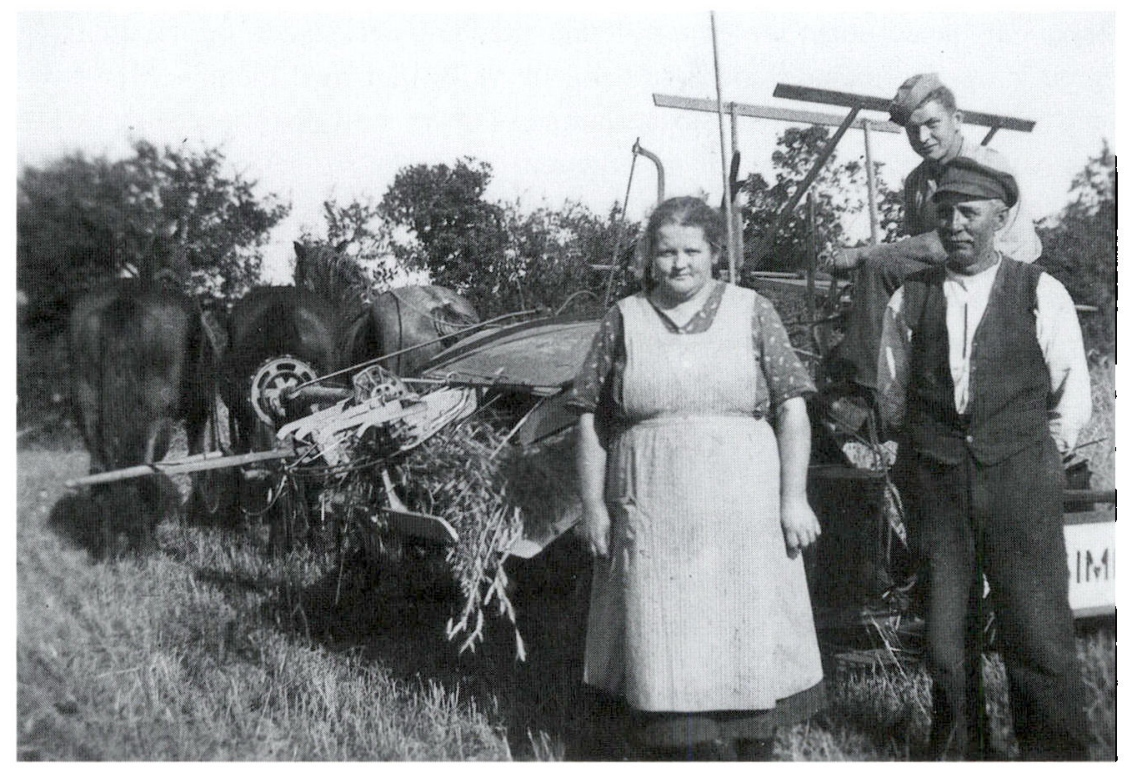

Anna og Friedrich Jessen og sennen Frederik ved selvbinderen. Foto 1935 i privateje.

våd sommer blev høsten vanskelig. Det kunne gå hen i september, inden negene var tørre nok til at blive kørt ind, og så blev der ingen pause inden kartoffeloptagningen. Den tog nu ikke lang tid, for vi avlede kun kartofler til eget forbrug.

Derefter kom turen til roerne, der skulle aftoppes, tages op og køres sammen $i$ en roekule på marken. Det var et arbejde, jeg holdt af. Sådan en rolig efterårsdag, når solen hen mod aften farvede himlen gul og rød og alt var stille, gik jeg og glædede mig over, at når vi var færdige med roerne og vintersæden var sået, var ringen sluttet for $\mathrm{i}$ år. Nu kunne det blive dejligt at få tid til det mere huslige, få ryddet op i skabe og skuffer, tøjet set efter, stoppet og lappet. Det blev tit lap ovenpå lap, men som bedstefar ved æ vej en gang havde sagt, da mor lappede hans underbukser: "Skidt med det, Anno, det værme åltsammel.«

Mor, der altid var fornuftig og tænkte på det praktiske, havde i tide gemt nogle ruller sytråd, hvide og sorte, og givet mig nogle med, da jeg flyttede hjemmefra. Det var et held, for det man kunne købe var så elendigt, at det brast hele tiden.

Om aftenen sad vi alle fire i aftægtsstuen; det sparede på både brændsel og petroleum. Der var ingen på Frøslevmark, der havde elektricitet, og under krigen var det næsten ikke til at få petroleum til lamperne. Vi måtte dog ikke 
klage. Far havde noget motorpetroleum stående i værkstedet, og når Frits og jeg en gang om måneden besøgte dem, fik vi 10 liter med hjem. - Men hvor det kunne ose. Når vi havde skruet lampen lidt for højt op, svavede der sorte fnug rundt i stuen. Luften var nu ikke ren i forvejen, for svigerfar kartede og svigermor sad ved rokken og spandt. Vi købte ulden hos naboen, selv havde vi ingen får. Det ene år fik vi også uld af et sort får, og dette garn kunne bruges til strømper uden at blive farvet.

Jeg strikkede meget, og det var interessant at få en pæn trøje ud af et par opslidte sweaters, der var trævlet op. Nogle små nøgler garnrester blev anvendt til en bort, eller også blev to farver strikket sammen, så trøjen blev meleret. Om vinteren gik jeg i tykke uldstrømper og ellers i nogle af mako, en slags bomuld. Hvis de var slidt op på hæl og tå, klippede jeg foden af dem, strikkede et par ankelsokker og syede dem fast på strømpeskafterne. Ingen kunne se "snyderiet

Når vi sådan sad sammen om aftenen og havde det rart, strejfede den tanke mig somme tider, at Frits's forældre nok i begyndelsen havde været lidt betænkelige ved, at deres søn ikke blev gift med en pige der var vant til »bønderiet«, og det kunne jeg såmænd godt forstå. Det varede dog ikke længe før de blev klar over, at jeg følte mig rigtig godt tilpas ved at rode i jorden og passe kalve, svin og høns.

Engang, da der blev problemer med en ung so, som ikke kunne føde grisene, sagde jeg, at mine hænder var smalle og jeg ville prøve på at være fødselshjælper. Mens de overraskede kiggede på mig, klippede jeg neglene helt korte, skrubbede hænderne rene og smurte den højre hånd og underarm godt ind med sæbe.

Ganske lempeligt listede jeg hånden ind $\mathrm{i}$ soen, fik fat $\mathrm{i}$ en gris lige bag ved ørerne og trak den forsigtigt ud. Den var spillevende, og det var de næste syv også, som kom til verden på samme måde. Glæden boblede i mig - sikken en oplevelse. Svigerfars beundring kendte ingen grænser. Det havde han nu alligevel ikke troet!

\section{Krigen rykker narmere}

Dagene gled videre i den sædvanlige rytme, men luftalarmerne blev hyppigere, og spærreballonerne kom op over Flensborg, når de engelske bombemaskiner fløj hen over os på vej mod deres mål i Tyskland.

Mange gange om natten blev vi vækket af sirenens hyl og tumlede ud af sengen for at søge dækning i kælderen. Een gang faldt tre bomber så tæt på, at det gik ud over naboens vinduer, og dørene blev slået skæve.

En morgen, da vi kom ud til græsmarken tæt ved huset, hvor køerne gik, var der i løbet af natten blevet nedkastet strimler af stanniol, som nu lå spredt 


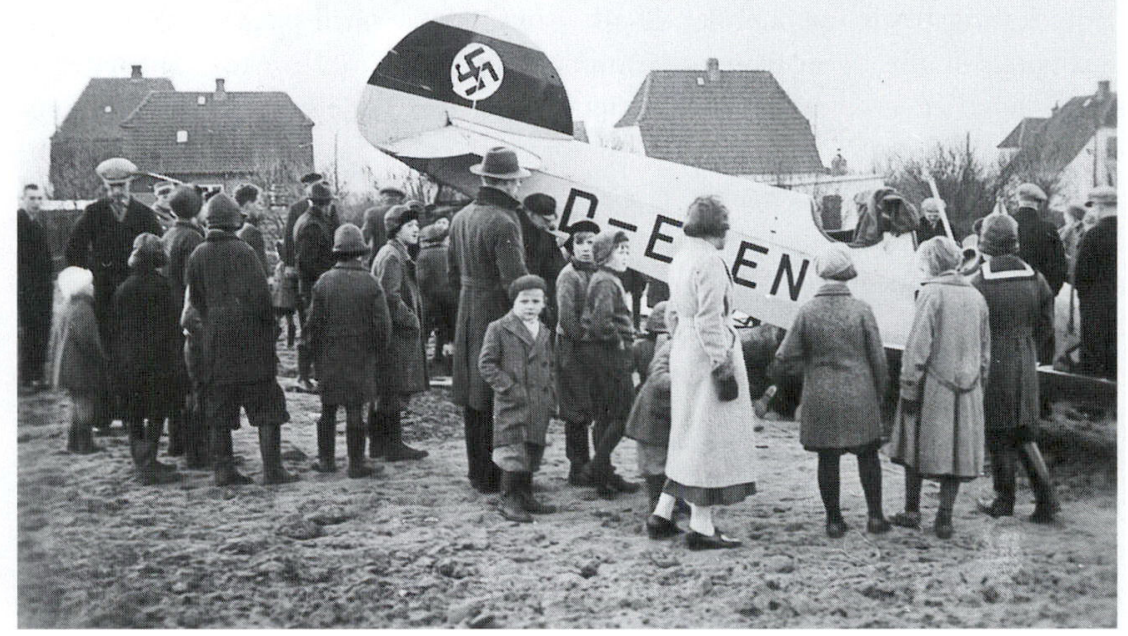

Tysk fly nodlandet på arealet mellem Froslevvej og Nygade. 1939. Foto: Bov lokalarkiv.

over det hele. Det var en slem forskrækkelse, for vi havde hørt at de var giftige for dyrene. Frits skulle nødvendigvis på markarbejde. Svigerfar og jeg fik i en fart fundet et par gamle blikdåser og to kæppe. Vi turde ikke røre ved det giftige stads med fingrene. En halv dag gik med at samle strimlerne op i dåserne, som derefter blev sat op på den allerøverste hylde i et skab oppe på loftet.

Senere fik vi at vide, at rygtet var falsk. Når de engelske maskiner fløj ind over landsdelen, blev disse strimler i store bunker kastet ned for at vildlede tyskerne i deres angreb. I det skarpe lys fra projektøren på vagttårnet hindrede de sølvglitrende bånd dem i at træffe deres mål. Vore møjsommeligt opsamlede "giftige« strimler blev stående på loftet til efter krigen og blev senere brugt som pynt i en dørranke til naboens sølvbryllup.

Krigen rasede stadig uden ophør. Hitler og hans stab blev mere og mere desperate. Jagten på jøderne og fangernes grusomme skæbne i de tyske koncentrationslejre var forfærdelig. Også herhjemme frygtede man SS og Gestapo, og det var ikke uden grund. Mange modstandsfolk var blevet arresteret og sad i danske fængsler. Alle gruede for, at de en dag ville blive transporteret over grænsen sydpå til udryddelseslejrene, gaskamrene i Tyskland.

For om muligt at forhindre dette, besluttede den danske stat at bygge en internerings- og fangelejr i Danmark, tæt ved grænsen, og valget faldt på et areal ved Frøslev Plantage. I august 1944 blev »Frøslevlejren« taget i brug.

Forinden var vejen fra Frøslev til Faarhus blevet spærret for gennemkørsel. 
I stedet for blev der anlagt en vej tværs over Frøslev Polde, lige igennem vore marker, der stødte helt op til lejren. En af markerne ønskede danskerne at leje til parkeringsplads for lastbiler, hvad vi også sagde ja til på den betingelse at den enten skulle tilbageleveres i samme stand, som de overtog den, eller vi skulle have en erstatning. Nogle steder blev der lagt brosten, andre steder cement til vaskeplads, og flere store benzintanke blev gravet ned i jorden. Efter krigen blev lejemålet overtaget af »Faarhuslejren « og senere »Padborglejren«. Da det hørte op, var det umuligt at fjerne alle de sten, cementblokke og jern, så jorden kunne pløjes. Vi fik en godtgørelse og plantede gran i arealet, det eneste, der kunne gro mellem skrottet.

Om vinteren, når vi ikke havde så travlt, ville Frits gerne tjene en ekstra skilling, hvad der jo også var hårdt brug for. Der var ikke mange bønder der havde eget tærskeværk. De fleste lejede det store tærskeværk, som kørte fra gård til gård. Her fik han plads som »ilægger«, d.v.s. den der skar negene op og skubbede dem ind i maskinen.

Hver dag cyklede han på arbejde, men en aften kom han oprørt og forbitret hjem og sagde: »Nu er det slut! « I skoven ved Faarhus var han blevet standset af to soldater, og mens den ene pegede på ham med sin maskinpistol, gennemrodede den anden alt, hvad han havde i bagagebæreren i den tro, at han var på vej til sabotage. Da de omsider blev klar over, at han intet havde at skjule, fik han endelig lov til at cykle videre.

Ude på Kragelundmark boede hans onkel og tante, som havde indbudt os til at komme på besøg en aften. Knap nok var vi cyklet hjemmefra, før vi blev indfanget af lyskasteren fra vagttårnet i Frøslevlejren, og de overvågede os hele vejen, indtil vi var stået af cyklerne og gået indenfor. Det var meget ubehageligt, men på den anden side var det lang tid siden, vi havde haft så god belysning at færdes ved ude i mørket.

Godt gemt af vejen, hvor ingen kan finde den, har jeg en tysk hjelm med hagekors, som jeg blev ejer af uden at jeg vidste det. Den skal ikke frem i lyset, for det er bestemt ikke et kært minde, men jeg vil vise den til mine efterkommere, når jeg fortæller dem om den tid, vi oplevede, og som for dem kun er en beretning fra Danmarkshistorien.

En sommerdag, mens jeg var alene hjemme, så jeg at der kom en flok soldater marcherende nede fra byen. Det tordnede og regnen styrtede ned. Hele flokken drejede ind på gårdspladsen, gik over i laden og kravlede ad en stige op på loftet, hvor de satte sig i halmen og sang, indtil det igen blev tørvejr. Et par dage efter, da jeg kom op på loftet, fik jeg øje på hjelmen. En soldat havde taget den af og glemt at få den med. Det har nok ikke været morsomt for ham at stå ret overfor en overordnet.

Sådan skete der så meget, som mere eller mindre bed sig fast i hukommel- 
sen, - f.eks. den lørdag vi glade og lykkelige på vej til Felstedskov var nået til Søgaard. Da vi drejede om hjørnet og så ned over søen for at nyde den smukke udsigt, gav det et sæt i mig. Hagekorset vajede over Søgaard kaserne!

Tavse cyklede vi videre og kom til æ Bjerreskov. På toppen af den højeste bakke stod en tysk officer med svaj i kasketten over den glatragede nakke og ryggen spændt som en flitsbue. Han kommanderede med soldaterne, der til ingen verdens nytte rasede rundt med tanks og ødelagde hele terrænet.

I Frøslev-Padborg området var der, ligesom mange andre steder, et par »stikkere« vi skulle tage os i agt for. Den ene var Max Pelving, en forhenværende dansk kriminalbetjent, der var blevet overløber og nu arbejdede som håndlanger for nazisterne. Efterhånden vidste vi alle, hvor i Frøslev, han havde sit tilholdssted.

For at følge med i, hvordan forholdene udviklede sig rundt omkring, hørte vi dagligt $\mathrm{BBC}$, den danske presse fra London. Også dette var strengt forbudt. Tyskerne havde en station lige ved siden af og forstyrrede udsendelserne med en larm og spektakel, så det kunne være svært at forstå den danske stemme. Hvis nogen uanmeldt bankede på døren i udsendelsestiden, skyndte vi os at slukke for radioen, - man kunne jo aldrig vide. Radioavisen fra Danmark, som naturligvis også stod under tysk kontrol, kunne vi næsten udenad: »Det er lykkedes de tyske jagere at nedskyde 18 (somme tider 21 eller 24) af fjendens maskiner «, mens de selv kun mistede 1 måske 2, lidt variation måtte der jo være $i$ antallet. Selvom Hitler og hans »Volksgenossen« aldrig ville indrømme det, var Tysklands overmagt svundet betydeligt ind. I den daglige radiomeddelelse hed det, at den tyske hær havde trukket sig sejrrigt 'og planmæssigt tilbage.

Når jeg tænker tilbage på besættelsestiden, er der en dag, jeg aldrig glemmer, - den dag, de danske grænsegendarmer blev transporteret til koncentrationslejrene i Tyskland. Det står så tydeligt for mig, som var det i går.

Rent tilfældigt kom jeg ned til købmanden og så, at der holdt en lastbil, hvorpå en flok gendarmer i deres lyseblå uniformer stod stuvet tæt sammen som kreaturer. Uskyldige mænd, som ikke havde gjort spor andet end at passe deres arbejde og gjort deres pligt.

Købmand Svend Jacobsen viste sig i døren med favnen fuld af cigaretter, tobak, chokolade, og hvad der ellers fandtes i butikken. Det hele smed han op på lastbilen, og det gik hurtigt, for den var begyndt at køre, - et vink og så var de borte, hvorhen vidste ingen. Mange af dem vendte aldrig tilbage for dem blev det et sidste farvel til Danmark.

Sommeren 1944, mens jeg alene var i gang med roehakningen på marken tæt op ad pigtrådshegnet ved Frøslevlejren, kom der med eet en engelsk maskine flyvende lavt henover jernbanen, forfulgt af tyske jagere. Luftalarmen hyle- 


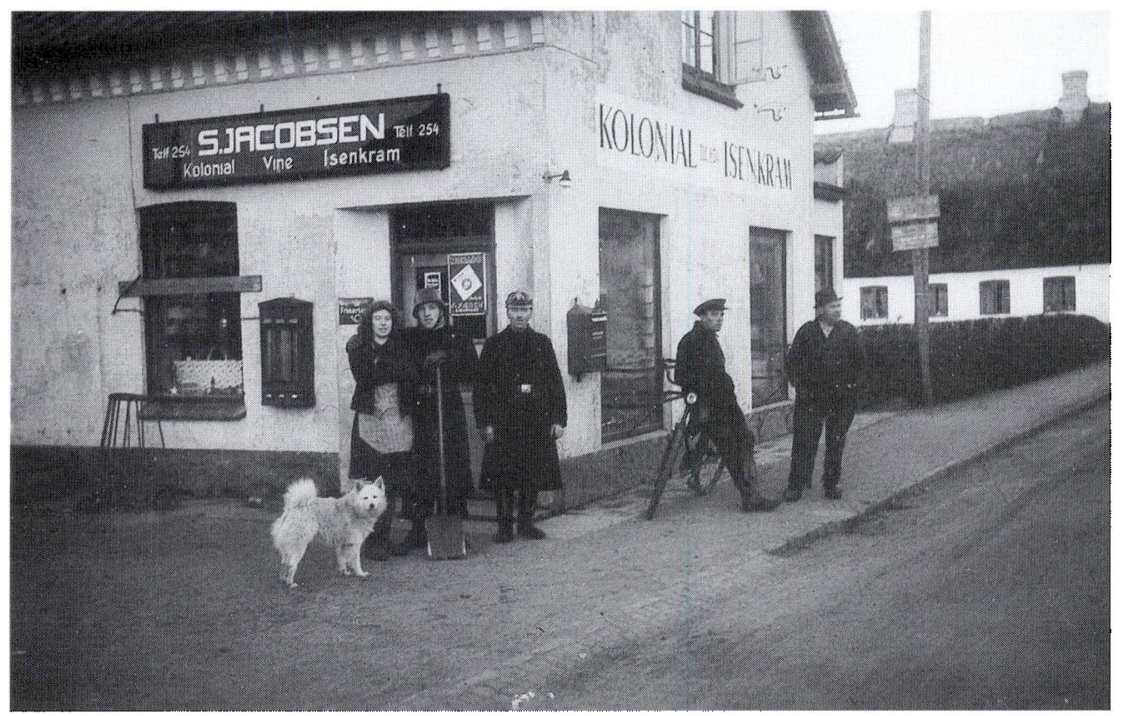

Her foran købmand Svend Jacobsens butik $i$ Frøslev gjorde lastbilen med gendarmerne holdt for turen sydpå til Neuengamme i 1944. Privateje.

de og skuddene knaldede. Jeg smed hakkeren, stak i løb, greb i forbifarten madkurven og sprang ned i en dyb grøft. Det varede dog ikke så længe, før skyderiet holdt op, og alarmen blev afblæst. Frits var helt nede i engen, og da han med bange anelser kom farende på cykel, sad jeg nede i grøften og spiste mit brød. - Sådan har jeg altid været, til daglig nervøs og ængstelig, men rolig og fattet, når der virkelig var noget at være bange for.

Krigen rykkede nærmere og nærmere. Flygtninge fra de bomberamte byer i Nordtyskland strømmede til Danmark. De fleste blev anbragt i flygtningelejre, og nogle fik husly hos tysksindede familier.

En tidlig forårsdag plantede svigerfar og jeg gran i den sandede mark, Agerende, bag ved savværket. Igen var der luftalarm, spærreballonerne kom op over Flensborg, og vi hørte den velkendte lyd af engelske bombemaskiner; alt sammen noget, der skete næsten hver dag. Men denne dag fortsatte englænderne ikke til Kiel, da gjaldt det Flensborg.

I luftlinje er der kun få km fra Flensborg til Frøslev. Vi hørte tydeligt braget, når de nedkastede bomber eksploderede, så flammerne skyde op og røgen fra de mange ildebrande brede sig over byen.

Foruden den dag, grænsegendarmerne blev kørt over grænsen ned til de tyske koncentrationslejre, er der en anden oplevelse, som heller aldrig vil gå $i$ glemme. Det var om foråret, i april 1945. Vi havde soveværelse i den vestlige del af huset, tæt ved vejen, der fører forbi til Frøslevlejren. Om natten vågnede 
vi begge ved en vedvarende brummen, og der var så mærkeligt lyst udenfor i haven. Vi sprang ud af sengene for at kigge ud af vinduet.

Aldrig glemmer jeg det syn, vi fik at se, og hvad jeg følte er ubeskriveligt. Det var virkeligt sandt, det var de hvide busser, der kom sydfra med frigivne fanger, syge, udhungrede stakler. Tårerne pressede på, - vi stod og knugede hinandens hænder til den sidste bus var passeret.

»De gamle«, mine svigerforældre, var et par gange kommet med en lille bemærkning om at de syntes, det var på tide vi fik en arving. Børn skulle man have, mens man var ung. Det svarede vi ikke rigtig på, men vi ville i hvert fald ikke sætte børn i verden i en tid, hvor vi måske ville blive udsat for at skulle flygte fra hus og hjem.

Kommunen havde jo allerede sendt meddelelse ud til alle, der havde køretøj, om hvem de skulle tage med, hvis evakuering blev nødvendig. For vort vedkommende var det en familie fra Bov. Alle husstande havde modtaget et skema som skulle udfyldes med oplysninger om alt hvad vi ejede af indbo, køkkengrej, sølvtøj, smykker og meget andet ifald det skulle gå tabt. Hvorfor ved jeg ikke. Nogen erstatning ville vi dog aldrig kunne få alligevel.

\section{Befrielsen}

Gudskelov sluttede krigen, så at sige lige udenfor døren, inden Sønderjylland igen kunne være blevet krigsskueplads. Den tyske Wehrmacht var i opløsning, kaos herskede overalt. Nu kunne det kun dreje sig om få dage. Spændt lyttede vi hver aften til BBC fra London, og da den danske stemme den 4. maj kom med meddelelsen om, at tyskerne havde overgivet sig og nedlagt våbnene, kendte jubelen ingen grænser. Krigen var endt, vi var igen et frit folk. Især i byerne var folk ellevilde, rev mørklægningsgardinerne ned, tændte lys over det hele og åbnede vinduer og døre. Man stimlede sammen på gaderne, sang og dansede. På landet tog vi det nok lidt mere roligt.

Befrielse, synes jeg, var en rammende betegnelse. Det var som om et tryk, et snærende bånd, blev løst op og man følte sig lettet og fri. Frøslevlejrens porte blev slået op, fangerne var ikke mere fanger, og uden for lejren blev der rejst en æresport.

$\mathrm{Nu}$ stod Frøslevlejren tom, men det varede ikke længe, før den blev fyldt med nye fanger, bl.a. de stikkere, der under besættelsen havde arbejdet for tyskerne, meldt frihedskæmperne - deres egne landsmænd - til Gestapo og været skyld i, at de blev udsat for tortur og skudt. Frøslevlejren kom nu til at hedde »Faarhuslejren«, en meget passende navneforandring.

En lille privat historie må vi også have med. Da Frits et par dage før kapitulationen var nede $\mathrm{i}$ byen for at høre nyt, kom han hjem med et skælmsk smil om munden, gav mig et kys og sagde med et muntert glimt i øjnene: „Så, 
Marie! No stæe æ englændere ved Flensborre, - hva mæn do no, min Pigh?« Jo, jeg mente da det samme som han, og halvandet år senere fik vi en dejlig stor dreng.

De to par bedsteforældre blev naturligvis meget glade, ikke mindst far, da han hørte, at drengen skulle hedde Christian Hesselholt Jessen.

\section{Fred og fremgang}

Krigen var forbi, men det betød ikke, at alt nu igen var som før. Danmark var blevet udsuget, og der gik flere år, før der atter var normale tilstande. Rationeringen hørte heller ikke op fra den ene dag til den anden. Jeg har gemt et par rationeringskort der viser, at de sidste kaffemærker blev udstedt i 1953.

Et par uger før jul i 1948 fik vi elektricitet, og det var dejligt. Nu kunne jeg endelig få det strygejern $\mathrm{i}$ brug, som vi havde fået $\mathrm{i}$ bryllupsgave for 6 år siden. Indtil nu havde jeg måttet klare mig med en strygepande, hvortil der hørte tre strygejern. Panden med strygejernene blev opvarmet på komfuret, og når et jern var blevet koldt under strygningen, blev det byttet med et andet. Der var jo mange andre elektriske hjælpemidler at få til husholdningen, men det måtte vente.

Det var mere nødvendigt at få nogle bedre og mere moderne landbrugsmaskiner, der sparede tid og var en lettelse i arbejdet. I 1950 havde vi sparet så mange penge sammen, at vi kunne få malkemaskine og vandværk. Vi købte aldrig noget på afbetaling. Det var alt for risikabelt. At drive landbrug er noget af et lotterispil. Høsten kan slå fejl, der kan komme sygdom i besætningen, - man ved sig aldrig sikker.

En gammel traktor blev også anskaffet. Frits vidste ikke noget bedre end at rode med brugte motorer og maskiner, der blev efterset, renset og malet, så de ikke var til at kende igen, og det lykkedes ham altid at få dem solgt. Så var den fortjeneste hjemme.

For svigermor og mig var vandværket nok den største aflastning. Alt vand til husholdningen havde vi jo før måttet hente ude i stalden, hvor der stod en meget stor pumpe, som skulle spædes hver gang, inden vandet kunne pumpes op. Storvasken var særlig besværlig på den måde, men vi havde god hjælp af svigerfar, der fyldte alle mejerispande med vand og bar dem ind $i$ vaskerummet. Om vinteren var det et problem at få tøjet tørt, for vi havde ingen anden tørreplads end staldloftet, og når det tykke vintertøj efter en uges tid kunne tages ned, var det halvsnavset af støv fra laden.

Et par år efter fik vi et rigtigt tæppe i opholdsstuen i stedet for linoleum, og så var det næsten ikke til at undvære en støvsuger. Der var jo altid aske og støv ved kakkelovnen, og det kunne ikke undgås, at der blev slæbt lidt avner og strå med ind fra stalden. Det næste vi fik var en vaskemaskine, der dog 
ikke var så god og nem som dem, vi har nu. Køleskab og fryseboks tænkte vi slet ikke på, - det var en fremtidsluksus, som man nu synes er uundværlig.

Hvert forår og efterår blev der slagtet et svin. Hjemmeslagteren var bestilt nogle dage i forvejen og kom meget tidligt om morgenen. Det var et par travle dage for os to kvindfolk med at rense og skrabe tarme, stege flommen af til fedtegrever, lave sylte, leverpostej og forskellige slags pølser. Mørbrad, ribben, nakke og andre kødstykker blev stegt i ovnen. De færdige retter kom i henkogningsglas, og der var så mange, at henkogningsgryden stod og rumlede på komfuret en hel dag, - til sidst rumlede det også inde i mit hoved.

Svigerfar tog sig af skinker, bov og nogle store stykker flæsk, der blev gnedet ind med groft salt og lidt salpeter, lagt i saltkarret og tildækket med endnu et lag salt. Efter ca. 4 uger blev det taget op og sendt til røgning.

Sikken en lettelse det var, da vi fik råd til at købe en brugt fryseboks. Bare skære flæsk og kød i passende stykker, pakke det ind og lægge det $\mathrm{i}$ boksen, færdig!

Også om sommeren var fryseren min gode ven. Bær og al anden frugt skulle blot skylles og fyldes rå i poser, for så at blive syltet om vinteren, når der var mere tid til rådighed.

\section{Landsbyliv $i$ forandring}

Ellers gled dage og uger af sted i en rolig rytme, som de jo gør ude på landet med afvekslende beskæftigelse, alt efter årstiderne. I Frøslev by gik naboerne til bys hos hinanden. Det var ikke almindeligt på Kaadnermark undtagen ved konfirmation, rund fødselsdag el.lign. Det hændte, at Frits og jeg spenderede en biografbillet på os selv, når der var en af de gode danske film på programmet.

Om sommeren var der ringridningen med efterfølgende bal på Frøslev Kro og om vinteren »æ Syngbal« med Frøslev Mandskor og dilettantforestilling, der ligeledes sluttede med en svingom til hen på de små timer. For nogles vedkommende kunne de lige nå at få skiftet tøj og gå i gang med morgenmalkningen.

Den mægtige kakkelovn gjorde hvad den kunne for at opvarme salen med det resultat, at vandet drev ned ad de oliemalede vægge. Tobaksrøgen bølgede under loftet, men der var heldigvis en luge, der kunne åbnes, så osen forsvandt den vej. Musikken satte altid i med Københavnermarchen, og så ilede bønderkarlene over gulvet til pigerne, der sad i rad og række på bænkene, ventende på at blive budt op. Nærmest kakkelovnen sad konerne og fulgte nysgerrigt de unge par med øjnene, hvem der dansede med hvem, og om der var udsigt til en forlovelse, - der hviskedes og tiskedes. Frøslev Sangforening og Mandskor havde eksisteret i mange år og gør det stadig. 


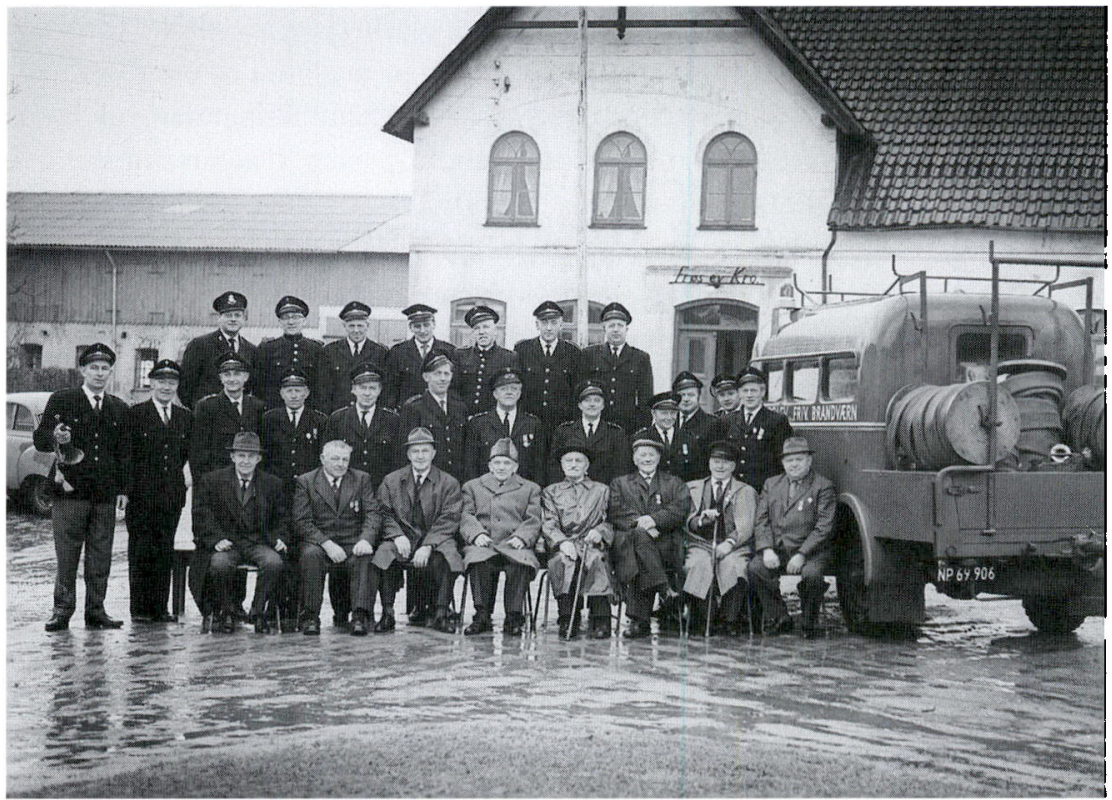

Froslev frivillige Brandvarns 80 års jubilaum 1966. Frederik Jessen ses som nr. tre i anden rakke fra højre. Privateje.

Også om hverdagen blev der sunget $\mathrm{i}$ byen. Når jeg cyklede til bageren efter brød og kom forbi den åbne port ind til smedjen, var det en fornøjelse at høre fædrelandssangene blande sig med hammerslagene fra ambolten. Jo! Familien Meyer kunne synge. Ved Genforeningen i 1920 blev det sagt, at Frøslev sang sig hjem til Danmark, og det var nok ikke helt forkert.

Frøslev by var en typisk landsby med købmand, bager, smed, skomager, sadelmager, maler, murer, karetmager, snedker, kro og mejeri. Tidens udvikling gjorde, at det kom til at gå hårdt ud over de små håndværkere og forretningsdrivende. Snedkeren flyttede til Padborg, men beholdt dog værkstedet i Frøslev. Alt andet blev nedlagt og mejeriet omdannet til fritidshjem.

I dag er kun Frøslev kro tilbage og trives i bedste velgående. Det er snart mange år siden, den blev overtaget af en ny ejer og moderniseret over det hele. Det er kun få aftener om ugen, hvor der ikke er lys i salen, - optaget som den er hele året rundt.

Frøslev havde sit eget frivillige brandværn, der blev oprettet i 1886. Frits var også medlem; vi boede ikke længere væk fra byen, end at vi sagtens, også om natten, kunne høre når der var brandalarm. Han fik det job at passe motoren, og det var lige noget for ham. I 1956 blev der holdt 70 års jubilæum på kroen, og der var sendt indbydelser ud til andre frivillige brandværn i omeg- 
nen. Det blev på alle måder en vellykket fest. En af de indbudte brandmænd sagde: "Vi kommer snart igen!«

Det gjorde de rigtignok også, endda hurtigere end de havde drømt om. Dagen efter, den 7.maj, udbrød der brand i Frøslev Mose, og ilden bredte sig hurtigt til den store Frøslev Plantage. Alle brandværn i vid omkreds blev

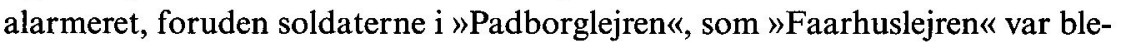
vet omdøbt til, efter at fangerne var blevet frigivet og militæret rykket ind den 1. november 1949. Også mange frivillige deltog i brandslukningen, bl.a. ved at pløje brandbælter. Det tog flere dage, før ilden var under kontrol, og der måtte stadig holdes vagt. Lugten af brand hang i luften lang tid efter at ilden var slukket.

\section{Nye tider}

Et år efter krigen havde vi jo fået vor førstefødte, Christian, og fire år senere fik vi endnu en dreng, som fik navnet Henry Hesselholt Jessen. De to drenge voksede godt til. Christian gik ud af skolen i ottende klasse og begyndte som bydreng på Padborg jernbanestation. Dengang var det eftertragtet at blive fast ansat ved staten. Christian blev også på stationen, indtil han indkaldtes som soldat til »Slesvigske Fodregiment« i Haderslev. Herfra kom han til Post- og Telegrafvæsenet, og er nu ansat ved Tele Sønderjylland i Aabenraa.

Henry tog realeksamen og blev antaget som maskinarbejderlærling på Danfoss. Dér er han fortsat, nu som værktøjskonstruktør.

Hjemme i Felstedskov stod tiden heller ikke stille. Min søster Christine og hendes forlovede havde holdt bryllup og kom til at føre forretningen videre, og så flyttede far og mor ind i lejligheden ovenpå.

På Frøslev Kaadnermark var det lykkedes for os at få lagt lidt penge til side på kistebunden. Frits' forældre havde ikke megen plads til rådighed i deres to stuer, og vi var enige om, at så meget som de havde hjulpet os, havde de $\mathrm{i}$ hvert fald fortjent at få en bedre bolig. Vi købte et lille hus med have til i Padborg, malede, tapetserede og gjorde det hele i stand fra ende til anden. Efteråret 1952 var det færdigt, så de kunne flytte ind. Der var mange på deres alder i Nygade, og de blev glade for at bo der.

Svigerfar kunne dog ikke helt undvære bønderiet. Han kom hver dag cyklende for at give et nap med og få en liter mælk med hjem. Svigermor havde ikke cyklet i flere år. Hun kom en gang imellem med rutebilen, der kørte ud til Padborglejren efter at lejren var blevet bemandet med soldater.

Nogle år efter krigens afslutning fik Padborg vokseværk. Flere og flere speditører og vognmænd slog sig ned i grænseområdet, - der blev bygget allevegne. Kommunen måtte til at skaffe flere byggegrunde og var interesseret $i$ et område på Frøslev Kaadnermark. Vi fik også en henvendelse om, at de ønskede at 
købe noget jord, der hørte til vor ejendom. Hvis vi nægtede at afstå arealet, ville det blive eksproprieret.

Det blev til mange forhandlinger om prisen, inden Frits sagde ja til handelen. Kommunens repræsentanter blev snart klar over, at han ikke var nem at overtale. Sønderjyderne har jo ord for at være stædige, han lod sig ikke rokke. Omsider blev de dog enige om beløbet, og det blev betalt kontant.

Vor ejendom var nu nedlagt, og kun $4.000 \mathrm{~m}^{2}$ jord var tilbage omkring bygningerne. Men så var der råd til en ombygning. Hele beboelseshuset blev nu moderniseret, hvad det også i høj grad trængte til. Den store, gamle skorsten blev revet ned til grunden. De rustne blikplader blev fjernet, der kom nyt tag på, og nye vinduer blev sat i på sydsiden af huset. Vi fik centralvarme, badeværelse, fliser i køkkenet og elektrisk komfur.

Da alt det var betalt, mente Frits, det var mere sikkert at satte resten af pengene $\mathrm{i}$ fast ejendom end $\mathrm{i}$ banken. Vi var så heldige at kunne købe 30 ha frijord uden bygninger i Bovlund, Nørre Rangstrup kommune. Det blev bortforpagtet til to bønder indtil oktober 1993. Derefter var udlejningen ikke mere rentabel, og det blev solgt.

Rundt omkring, hvor vi boede, var store maskiner i gang med at gøre arealet byggemodent, og det varede ikke længe, før de første bygninger skød op. Industriområdet bredte sig.

Når jeg nu om aftenen ser det hav af lys, der er over industriområdet, tænker jeg på Frits’ oldemor, - hun var nemlig synsk. Dengang hun for mange år siden, da ingen kendte til andet end petroleumslamper, spåede, at der engang ville komme mange lys på Kaadnermarken, så mange, at de kunne oplyse det hele, lo man ad hende, - og hvad nu?

Efter at jorden og dyrene var solgt, blev vores hverdag helt anderledes. Frits prøvede $\mathrm{i}$ et par år forskelligt arbejde og fandt til sidst ud af, at han havde mest lyst til havearbejde, og det var der nok af i både Padborg, Bov og Kollund, langt mere end han kunne overkomme.

Årene gik. Frits' forældre fyldte snart 80 år. Hans far klarede sig stadig godt, men hans mor havde svært ved at overkomme den daglige rengøring og madlavning. Det var ved at blive en trist tilværelse for dem begge, og sådan kunne det ikke blive ved med at gå. Vi måtte finde en udvej, og så blev der igen sendt bud efter håndværkerne. Halvdelen af den tomme stald blev bygget fuldstændigt om til en moderne lejlighed. Sidst i april 1967 kørte Frits til Padborg for at hente sine forældre hjem til Kaadnermark. Vi havde købt bil tre år i forvejen.

De fik et par gode år sammen og kunne i februar 1969 fejre guldbryllup. Fra en bekendt havde vi fået et vink om, at beboerne i Frøslev regnede med at guldbrudeparret ville køre gennem byen om aftenen ca. kl. 10. Det ville de 


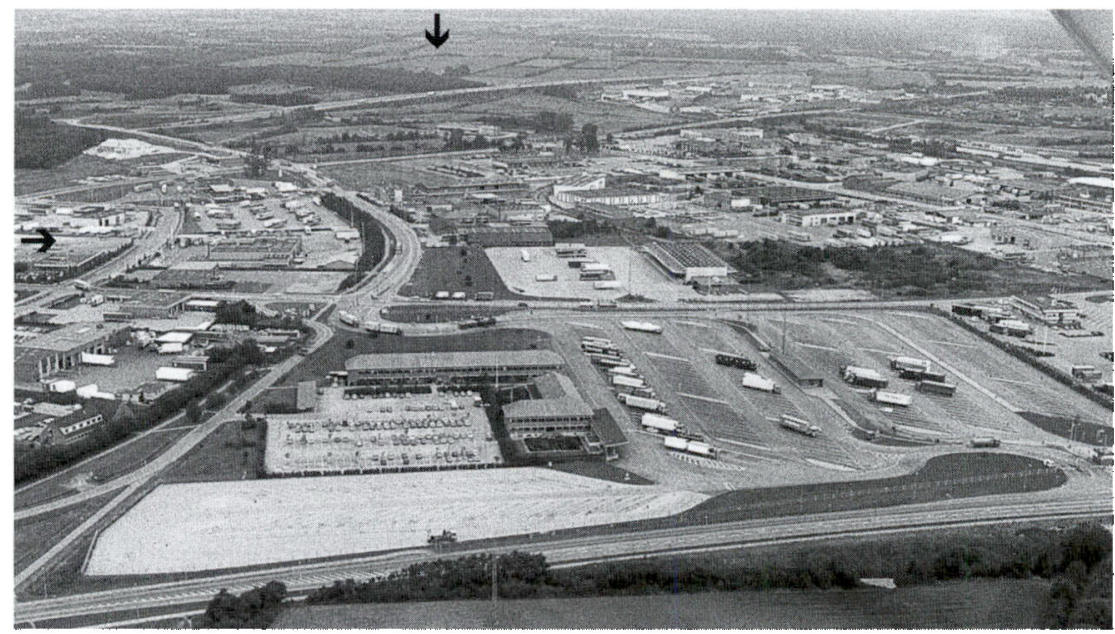

Anlagget frem til 1976-78 af motorvejen, det nye toldområde og de mange speditionsfirmaer nordvest for Froslev blev enden for ejendommen på Froslev Kådnermark. På dette luftfoto fra 1992 aner man resterne af Jessen-ejendommen, hvor de to pile modes. Foto: Ernst Winckelmann.

gerne, og det var som et triumftog. Vi var fire biler, der i langsomt tempo kørte ned ad Nørregade og fortsatte ud gennem Vestergade. Der var levende lys i alle vinduer, overalt stod folk udenfor og vinkede, og jeg kunne se, hvor det glædede de to gamle mennesker. De boede hos os til det sidste. Svigermor døde i 1970, svigerfar i 1975 .

Frits og jeg var nu alene tilbage på ejendommen. Men det blev kun kort. Den 8. december 1975 døde min kære mand - blot ti måneder efter sin far.

Da brast det for mig - jeg kunne ikke mere. En svær tid fulgte. Da jeg var kommet gennem det værste, kunne jeg nok indse, at det i længden ikke duede, at jeg blev boende på Kaadnermark. Ejendommen var jo nedlagt, men der var alligevel et stort areal at holde rent omkring bygningerne, der var alt for store til en enlig. Udbygningerne stod tomme, og det hele krævede vedligeholdelse.

En anden ting var, at industrien havde fortrængt det rolige landboliv. Et stort toldområde var blevet opført ganske tæt ved. Store kølevogne og lastbiler osede og larmede døgnet rundt, inden de fortsatte sydpå over grænsen. I samråd med mine sønner besluttede jeg at købe hus i Padborg og i første omgang udleje stuehuset på Kaadnermark - det blev solgt et år senere.

Vi købte et solidt hus med kælder, der var bygget i 1967. Der var en god have til, og her fik jeg plads til buske, blomsterløg og stauder fra vor dejlige have på Kaadnermark. 


\section{Pensionistglader}

Jeg flyttede til Padborg den 20. november 1976 og er glad for at bo her, hvor der er flinke naboer.

I Bov Sogn er der, ligesom så mange andre steder, en frivillig besøgstjeneste, og da jeg havde både tid og lyst, meldte jeg mig til det. Som besøgsven fik jeg Bothilde Hansen, »æ Skoelmestekuen« i Kollund, og jeg kunne ikke have fået nogen bedre.

Vi havde een stor fælles interesse, - kærligheden til Sønderjylland. Historien, landskabet, fortidsminderne og ikke mindst den kønne sønderjydske dialekt. »Æ Skoelmesterkuen« havde skrevet utallige digte på sønderjydsk, men var nu næsten blind. Det var meget svært for hende, der altid så gerne ville læse, skrive eller lave håndarbejde, og det glædede hende, når jeg sad og læste højt for hende en times tid. Hun fik mig også i gang med at skrive vers på sønderjydsk; det blev dog ikke til så meget i sammenligning med, hvad hun havde kunnet præstere. Det sker dog af og til, at jeg bliver spurgt om at læse mine digte op i forskellige foreninger, og det siger jeg med glæde ja til.

Jeg besøgte »Tilde« - »æ Skoelmesterkuen « - en eftermiddag i hver uge, og det var interessant at høre hende fortælle om alt, hvad hun havde oplevet for længe siden, da Sønderjylland hørte med til det tyske rige.

Sommetider, mens jeg var der, kom Kæthe Hinrichsen, der var hendes nabo, også ind til en kop kaffe. Når vi tre sad og snakkede sammen, prøvede vi nogle gange for sjov, hvor mange gamle sønderjyske ord, vi kunne huske.

Bothilde Hansen blev 87 år og døde i 1984. Efter hendes begravelse sagde Kæthe til mig: "No må do it glem vos hænée i Kollund «. Og så fortsatte jeg med at være hendes besøgsven indtil hendes død i 1991. Kæthe Hinrichsen blev 93 år.

Efter de to gamle damers død meldte jeg mig ud af besøgstjenesten. Vi havde nemlig i mellemtiden åbnet "Kirkens Korshærs « Genbrugsbutik i Padborg. To af mine bekendte havde i nogle år været medarbejdere ved en sådan butik i Aabenraa og medbragt brugt tøj fra Padborg og omegn. Hvorfor ikke selv beholde tøjet og åbne en butik i Padborg?

Det var en god idé, og vi var til at begynde med seks damer, der fik lejet og indrettet et meget forsømt lokale i en kælder. Vi puklede i et par uger med at gøre rent, male, anbringe hylder, stativer o.s.v. Til opvarmning var der kun en gammel utæt kakkelovn, som slugte en masse brændsel, og varmen røg lige op gennem skorstenen. Senere fik vi et par elektriske radiatorer, men det blev en dyr opvarmning.

I fem år havde vi butikken, som blev åbnet den 7. august 1984, men beliggenheden var ikke god, så da vi fik chancen for at leje et lokale "på strøget" slog vi til. Der er god plads og udstillingsvinduer lige ud mod gaden. Nu er vi 23 medarbejdere, og salget er tredoblet. Alt overskud bliver i Danmark og 


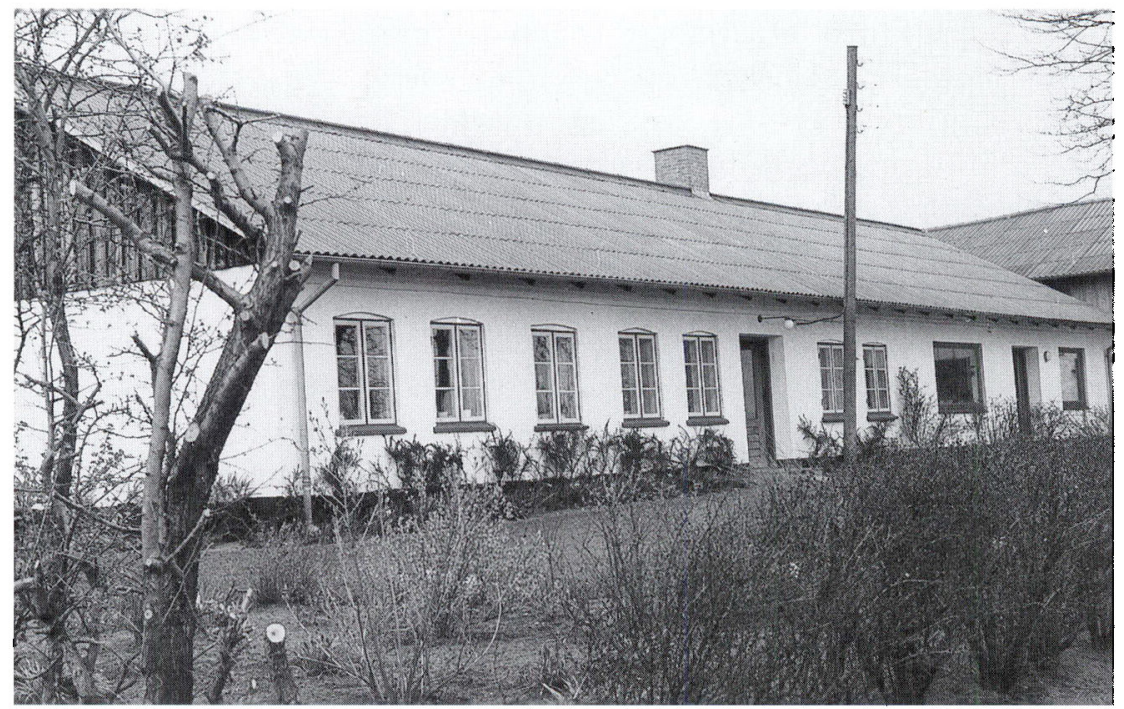

Ejendommen på Froslev Kådnermark efter ombygningen i 1967. Privateje.

sendes til hovedkontoret i København, hvorfra det så bliver anvendt der, hvor behovet er størst, - blandt mennesker, der er havnet så langt nede i elendigheden, at de er opgivet af det sociale system.

Foruden arbejdet med butikken holder vi den første torsdag eftermiddag $\mathrm{i}$ hver måned »Åbent Hus« i konfirmandstuen »Kirkeladen« i Bov Præstegård, hvor alle, uanset alder, er velkomne. Vi skiftes til holdvis at sørge for bagning af boller, lagkager og småkager samt borddækning, kaffe og opvask. Der er forskellig underholdning med foredrag, sang og musik, lysbilleder, oplæsning el.a. Der plejer at være 40 - 50 besøgende, mest ældre, der er glade for at hygge sig og få en snak med gamle bekendte i kaffepausen. I juni måned tager vi på en eftermiddagsudflugt i omegnen.

I Felstedskov hos min søster og svoger gik det ikke mere så godt med forretningen, efter at de store supermarkeder var dukket op. Små butikker kunne ikke konkurrere med priserne og blev tvunget til at lukke. Sådan gik det desværre også på Hesselholt.

Efter fars død i 1952 blev mor naturligvis boende på Hesselholt hos min søster og svoger, indtil hun efter mange års forløb kom på plejehjem i Aabenraa. Jeg er glad for, at jeg var hos hende den dag hun døde - det var i 1981.

Hver sommer tager jeg to uger på pensionisthøjskole, og det ville jeg meget nødigt undvære. Det kan naturligvis ikke sammenlignes med at sidde på skolebænk og lære lektier. Kursister fra alle egne af landet mødes på højskolen, 
kalder hinanden ved fornavn og er som een stor familie. Hvad vi er og hvad vi har bliver ikke diskuteret, - ligeså lidt som politik.

Der er mange valgfri fag, også kreative. Man kan f.eks. gå til foredrag, lysbilleder, sang og musik, gruppearbejde og lignende om formiddagen, og om eftermiddagen i værkstedet, hvor der bl.a. er syning, keramik, tegning og maling. Allerede som skolepige havde jeg stor lyst til at tegne og arbejde med farver, men aldrig haft tid til det før nu.

Tiden går hurtigt, alt for hurtigt på et højskoleophold. Der sker noget hele tiden, alle timer er besat, kun afbrudt af en hvilepause midt på dagen efter middagsmaden. En halv- og en heldagsudflugt til skønne egne i Danmark bliver der dog altid tid til. Efter afskedsfesten den sidste aften går det atter hjemad, og der går et par dage med at fordøje al den megen visdom, før man igen er i den gamle gange.

Jeg har flere gange hørt ældre folk sige, at de ikke ved, hvordan de skal få tiden slået ihjel. Det er ikke rigtigt: Tiden skal ikke slås ihjel. Den har vi fået for at bruge og udnytte den på bedste måde. Selvom man bliver gammel, er der stadig noget at glæde sig over, når blot man har øje for det, - de bedste glæder er gratis.

Frits og jeg ønskede tit, at vi kunne holde ferie en uges tid og tage lidt ud og se os om; måske en tur til Norge. Men det kunne ikke lade sig gøre. Arbejdet skulle passes, - og så blev det for sent.

Nu tænker jeg ikke mere på at rejse til udlandet; der er så mange smukke egne herhjemme, hvor jeg aldrig har været.

I min alder er det herligt at have energien og virkelysten i behold, og blev mit livsforløb ikke som et H.C. Andersens eventyr, så er det dog eventyrligt, hvad vor (min) generation har oplevet af store, nationale begivenheder og værdifuld udvikling siden Genforeningen i 1920. Hele min tilværelse har været og er stadig indholdsrig. Der er altid noget at glædes over, når blot man har øje for det. De bedste glæder er gratis. Ser vi på verdenskortet, er vort fædreland kun som en lille ubetydelig plet, men

»Jeg vil ikke bytte med nogen mand på jord

og jeg vil aldrig flytte fra denne plet i nord, «

fra denne lille oase, der hedder Danmark. 